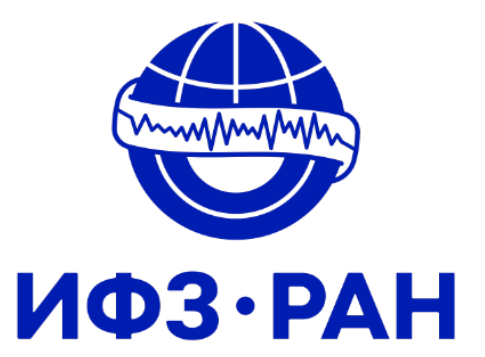

Федеральное государственное бюджетное учреждение науки

Институт физики Земли им. О. Ю. Шмидта

Российской академии наук

\title{
Научная конференция молодых ученых и аспирантов ИФЗ РАН
}

27-29 октября 2021 года

\author{
Тезисы докладов \\ и программа Конференции
}

Москва - 2021 
УДК 55

ББК $26.3 я 43$

H34

H34 Научная конференция молодых ученых и аспирантов ИФЗ РАН: Тезисы докладов и программа конференции. Москва, ИФЗ РАН, 27-29 октября 2021 г. М.: ИФЗ РАН, 2021 $-77 \mathrm{c}$.

ISBN 978-591682-064-5

https://doi.org/10.21455/molkonf2021

В сборнике публикуются тезисы докладов Научной конференции молодых ученых и аспирантов ИФЗ РАН, которая состоялась 27-29 октября 2021 г. в Институте физики Земли им. О.Ю. Шмидта РАН, Москва. Представлены результаты научных исследований по геофизике и смежным областям наук о Земле (геология, геодезия, геоэкология), полученные при участии молодых ученых, аспирантов и студентов.

This issue contains abstracts of the Scientific Conference of Young Scientists and $\mathrm{PhD}$ students of the IPE RAS, which held at the Schmidt Institute of Physics of the Earth Russian Academy of Sciences, Moscow (October 27-29, 2021). The results of scientific research in geophysics and related fields of Earth sciences (geology, geodesy, geoecology) obtained with the participation of young scientists, graduate students and students are presented.

Ответственный редактор:

д.г.-М.н. Р.В. Веселовский

Редактор: к.г.-м.н. А.М. Фетисова

УДК 55

ББК $26.3 я 43$

ISBN 978-591682-064-5

https://doi.org/10.21455/molkonf2021 


\section{Оргкомитет Конференџии}

\section{Председатель оргкомитета конференции:}

Веселовский Р.В. - заместитель директора ИФЗ РАН по научной работе, профессор РАН, д.Г.-М.н.

Заместитель председателя оргкомитета конференции:

Фетисова А.М. - инженер лаборатории 105, к.г.-м.н.

\section{Члены оргкомитета:}

Лиходеев Д.В. - учёный секретарь ИФЗ РАН, к.ф.-м.н., учёный секретарь конференции Андреев А.С. - заместитель руководителя департамента по связям с общественностью Афанасьева Л.В. - старший научный сотрудник лаборатории 601 Стрельников А.А. - научный сотрудник лаборатории 304 Иванов С.Д - научный сотрудник лаборатории 501

\section{Программный комитет Конференщии}

\section{Председатель Программного комитета Конференции:}

Тихоцкий С.А. - директор ИФЗ РАН, чЛ.-корр. РАН, д.ф.-м.н.

\section{Заместитель председателя программного комитета конференции:}

Веселовский Р.В. - заместитель директора ИФЗ РАН по научной работе, профессор РАН, Д.Г.-М.н.

\section{Члены программного комитета:}

Собисевич А.Л. - заместитель директора ИФЗ РАН по научной работе, чЛ.-корр. РАН, д.ф.-м.н.

Камзолкин В.А. - заместитель директора ИФЗ РАН по научной работе, к.г.-м.н.

Татевосян Р.Э. - заместитель директора по вопросам инженерной сейсмологии и оценке сейсмической опасности, д.ф.-м.н.

Анисимов С.В. - директор ГО "Борок", д.ф.-м.н.

Пономарёв А.В. - руководитель научного направления "Физика сейсмического процесса и горных пород", д.ф.-м.н.

Конешов В.Н. - руководитель научного направления "Потенциальные поля", д.т.н.

Лиходеев Д.В. - учёный секретарь ИФЗ РАН, к.ф.-м.н., учёный секретарь конференции Павлов В.Э. - заведующий лабораторией 105, д.ф.-м.н.

Овсюченко А.Н. - заведующий лабораторией 701, к.г.-м.н.

Дубиня Н.В. - с.н.с. лаборатории 202, к.ф.-м.н.

Жостков Р.А. - с.н.с. лаборатории 703, к.ф.-м.н.

Казначеев П.А. - с.н.с. лаборатории 301, к.т.н.

Маринин А.В. - с.н.с. лаборатории 204, к.г.-м.н.

Ученый секретарь конференции:

Лиходеев Д.В. - ученый секретарь ИФЗ РАН, к.ф.-м.н. 


\section{Программа конференции}

Среда, 27 октября 2021 г.

Доклады в конференц-зале ИФЗ РАН

Запись докладов доступна по ссылке: https://youtu.be/Q3OrS3xrcqY

\begin{tabular}{|c|c|c|c|}
\hline $\begin{array}{c}\text { Время } \\
\text { начала } \\
\text { доклада }\end{array}$ & ФИО докладчика & Название доклада & $\begin{array}{c}\text { Место } \\
\text { работы/учебы } \\
\text { автора доклада }\end{array}$ \\
\hline 09:50 & \multicolumn{3}{|c|}{ ОТКРЫТИЕ КОНФЕРЕНЦИИ } \\
\hline $10: 00$ & $\begin{array}{c}\text { СТАРИКОВА } \\
\text { Анастасия Юрьевна }\end{array}$ & $\begin{array}{l}\text { Роли пиар специалистов в научных } \\
\text { организациях на примере ИФЗ РАН }\end{array}$ & ИФЗ РАН \\
\hline $10: 15$ & $\begin{array}{c}\text { ЖОСТКОВ } \\
\text { Руслан } \\
\text { Александрович }\end{array}$ & $\begin{array}{c}\text { О сотрудничестве Института физики Земли } \\
\text { им. О.Ю. Шмидта Российской академии наук } \\
\text { и Русского географического общества в } 2020 \\
\text { и } 2021 \text { годах }\end{array}$ & ИФЗ РАН \\
\hline $10: 30$ & $\begin{array}{c}\text { СЕНЦОВ } \\
\text { Алексей Андреевич }\end{array}$ & $\begin{array}{c}\text { Предварительные результаты изучения } \\
\text { новейшей активности островов Уруп и } \\
\text { Чирпой по итогам экспедиции «Восточный } \\
\text { бастион - Курильская гряда 2021» }\end{array}$ & ИФЗ РАН \\
\hline $10: 45$ & $\begin{array}{l}\text { ИВАНОВ } \\
\text { Станислав } \\
\text { Дмитриевич }\end{array}$ & $\begin{array}{c}\text { Применение беспилотных летательных } \\
\text { аппаратов в условиях полевых геологических } \\
\text { работ }\end{array}$ & ИФЗ РАН \\
\hline $11: 00$ & $\begin{array}{c}\text { ХОЛОДКОВ } \\
\text { Кирилл Игоревич }\end{array}$ & $\begin{array}{c}\text { Подготовка оперативных } \\
\text { гелиогеофизических данных для Центра } \\
\text { космической погоды в интересах } \\
\text { безопасности авиаперелётов }\end{array}$ & ИФЗ РАН \\
\hline \multicolumn{4}{|c|}{ ПЕРЕРЫВ 15 минУТ } \\
\hline $11: 30$ & $\begin{array}{l}\text { МАНУИЛОВА } \\
\text { Екатерина } \\
\text { Алексеевна }\end{array}$ & $\begin{array}{c}\text { Связь новейшего структурного плана } \\
\text { Западно-Сибирской плиты с древними } \\
\text { дислокациями и месторождениями } \\
\text { углеводородов }\end{array}$ & ИФЗ РАН \\
\hline $11: 45$ & $\begin{array}{c}\text { ПЕРЕДЕРИН } \\
\text { Фёдор Викторович } \\
\end{array}$ & $\begin{array}{c}\text { Экспериментальное сравнение ГНСС } \\
\text { приёмников и ГНСС антенн }\end{array}$ & ИФЗ РАН \\
\hline $12: 00$ & $\begin{array}{l}\text { МЕЛЬНИК } \\
\text { Геннадий } \\
\text { Эдуардович }\end{array}$ & $\begin{array}{c}\text { Исследование постледниковых движений } \\
\text { Фенноскандии по зарубежным и российским } \\
\text { данным ГНСС }\end{array}$ & ИФЗ РАН \\
\hline $12: 15$ & $\begin{array}{c}\text { ГРИДЧИНА } \\
\text { Мария Сергеевна }\end{array}$ & $\begin{array}{c}\text { Исследование сейсмотектонических } \\
\text { деформаций о. Сахалин по данным } \\
\text { спутниковой геодезии } \\
\end{array}$ & ИФЗ РАН \\
\hline $12: 30$ & $\begin{array}{l}\text { ФАТТАХОВ } \\
\text { Евгений } \\
\text { Альбертович }\end{array}$ & $\begin{array}{c}\text { Построение главных осей сжатия и } \\
\text { растяжения по светодальномерным данным } \\
\text { на Камчатском геодинамическом полигоне } \\
\text { методом тензометрического анализа }\end{array}$ & ИФЗ РАН \\
\hline & \multicolumn{3}{|c|}{ ПЕРЕРЫВ 15 мИНУТ } \\
\hline 13:00 & $\begin{array}{c}\text { ЛАТАНОВА } \\
\text { Елена } \\
\text { Александровна }\end{array}$ & $\begin{array}{c}\text { Определение направлений естественной } \\
\text { остаточной намагниченности самоедской } \\
\text { свиты в долине р. Верхняя Таловая } \\
\text { (Норильский район) }\end{array}$ & ИФЗ РАН \\
\hline $13: 15$ & $\begin{array}{c}\text { ПАСЕНКО } \\
\text { Александр } \\
\text { Михайлович }\end{array}$ & $\begin{array}{l}\text { Результаты палеомагнитного исследования } \\
\text { лампрофиров Томторского щелочного } \\
\text { массива (север Сибирской платформы) }\end{array}$ & ИФЗ РАН \\
\hline $13: 30$ & $\begin{array}{c}\text { ЛЕБЕДЕВ } \\
\text { Иван Евгеньевич }\end{array}$ & $\begin{array}{c}\text { Проблемы стратиграфии и возраста } \\
\text { формирования вулканитов северной части } \\
\text { Охотско-Чукотского вулканического пояса }\end{array}$ & ИФЗ РАН \\
\hline
\end{tabular}




\begin{tabular}{|c|c|c|c|}
\hline $13: 45$ & $\begin{array}{c}\text { ФЕДЮКИН } \\
\text { Иван } \\
\text { Владимирович }\end{array}$ & $\begin{array}{c}\text { Позднепалеозойский этап формирования } \\
\text { северного сегмента Центрально-Азиатского } \\
\text { складчатого пояса: палеомагнитные } \\
\text { ограничения } \\
\end{array}$ & ИФЗ РАН \\
\hline & \multicolumn{3}{|c|}{ ОБЕДЕННЫЙ ПЕРЕРЫВ 1 час } \\
\hline $15: 00$ & $\begin{array}{l}\text { СТРЕЛЬНИКОВ } \\
\text { Андрей Андреевич }\end{array}$ & $\begin{array}{c}\text { Активная тектоника и палеосейсмичность } \\
\text { вдоль Краевого и Адырных разломов } \\
\text { северной части Иссык-Кульской котловины } \\
\text { (Кыргызстан, Тянь-шань) }\end{array}$ & ИФЗ РАН \\
\hline $15: 15$ & $\begin{array}{c}\text { МАТВЕЕВ } \\
\text { Максим Алексеевич } \\
\end{array}$ & $\begin{array}{c}\text { Фазовые превращения геоматериала при } \\
\text { сейсмических скоростях подвижки }\end{array}$ & ИФЗ РАН \\
\hline $15: 30$ & $\begin{array}{c}\text { БЕРЕЗИНА } \\
\text { Ирина } \\
\text { Александровна } \\
\end{array}$ & $\begin{array}{c}\text { Особенности моделирования эффективных } \\
\text { упругих свойств карбонатных пород в } \\
\text { масштабе керна } \\
\end{array}$ & ИФЗ РАН \\
\hline $15: 45$ & $\begin{array}{l}\text { НАСРЕТДИНОВА } \\
\text { Диана Ильдаровна }\end{array}$ & $\begin{array}{c}\text { Исследование неоднозначности решения } \\
\text { обратных задач петроупругого } \\
\text { моделирования с помощью нейронной сети } \\
\end{array}$ & ИФЗ РАН \\
\hline \multirow[t]{2}{*}{$16: 00$} & $\begin{array}{c}\text { МЕНЩИКОВА } \\
\text { Тамара Ивановна }\end{array}$ & $\begin{array}{c}\text { Нагрузочные числа Лява для различных } \\
\text { моделей неоднородной упругости Венеры }\end{array}$ & ИФЗ РАН \\
\hline & \multicolumn{3}{|c|}{ ПЕРЕРЫВ 15 минут } \\
\hline $16: 30$ & $\begin{array}{c}\text { БОНДАРЬ } \\
\text { Иван } \\
\text { Владимирович } \\
\end{array}$ & $\begin{array}{c}\text { Результаты исследований двух локальных } \\
\text { районов в зоне влияния Имандра-Колвицкого } \\
\text { разлома (Кольский полуостров) }\end{array}$ & ИФЗ РАН \\
\hline $16: 45$ & $\begin{array}{c}\text { ФАДЕЕВА } \\
\text { Карина Васильевна } \\
\end{array}$ & Новейшая геодинамика Большого Кавказа & МГУ \\
\hline $17: 00$ & $\begin{array}{c}\text { РОДИНА } \\
\text { Татьяна Андреевна }\end{array}$ & $\begin{array}{c}\text { Особенности методики многооконного } \\
\text { синхронного мониторинга временной } \\
\text { изменчивости МТ/МВ передаточных } \\
\text { операторов }\end{array}$ & ИФЗ РАН \\
\hline $17: 15$ & $\begin{array}{c}\text { ГРАЧЕВА } \\
\text { Дарья Алексеевна }\end{array}$ & $\begin{array}{c}\text { Массив синхронных МТ/MВ зондирований } \\
\text { EarthSсоре: многоточечное оценивание и } \\
\text { анализ передаточных операторов в активном } \\
\text { регионе северо-запада США } \\
\end{array}$ & ИФЗ РАН \\
\hline \multirow[t]{2}{*}{$17: 30$} & $\begin{array}{c}\text { РЯЗАНОВА } \\
\text { Мария Валерьевна }\end{array}$ & $\begin{array}{c}\text { Определение ориентации трещин в } \\
\text { различных масштабах с использованием } \\
\text { теории эффективных сред } \\
\end{array}$ & ИФЗ РАН \\
\hline & \multicolumn{3}{|c|}{ ПЕРЕРЫВ 15 мИНУТ } \\
\hline 18:00 & $\begin{array}{c}\text { КЛОКОВ Илья } \\
\text { Анатольевич }\end{array}$ & $\begin{array}{c}\text { Результаты обработки геологических стресс- } \\
\text { индикаторов южной части Кандалакшского } \\
\text { залива } \\
\end{array}$ & ИФЗ РАН \\
\hline $18: 15$ & $\begin{array}{l}\text { ЧИСТЯКОВА } \\
\text { Альвина } \\
\text { Владимировна }\end{array}$ & $\begin{array}{c}\text { Применение Рамановской спектроскопии для } \\
\text { локализации источников сноса обломочного } \\
\text { циркона }\end{array}$ & МГУ \\
\hline $18: 30$ & $\begin{array}{c}\text { ПАВЛЕНКО } \\
\text { Василий } \\
\text { Александрович }\end{array}$ & $\begin{array}{c}\text { Анализ пространственно-временных } \\
\text { вариаций магнитуды представительной } \\
\text { регистрации землетрясений на Камчатке }\end{array}$ & ИФЗ РАН \\
\hline $18: 45$ & $\begin{array}{c}\text { ШУКУРОВ } \\
\text { Зухриддин } \\
\text { Фазлиддинович } \\
\end{array}$ & $\begin{array}{c}\text { Определение толщины земной коры по } \\
\text { состоянию равновесия Эйри (на примере } \\
\text { Восточного Узбекистана) }\end{array}$ & $\begin{array}{l}\text { ИС АН РУз, } \\
\text { Ташкент }\end{array}$ \\
\hline
\end{tabular}


Четверг, 28 октября 2021 г.

Дистанционные доклады с использованием платформы Jitsi Запись докладов доступна по ссылке: https://youtu.be/W0Ea-noBBbM

\begin{tabular}{|c|c|c|c|}
\hline $\begin{array}{c}\text { Время } \\
\text { начала } \\
\text { доклада }\end{array}$ & ФИО докладчика & Название доклада & $\begin{array}{c}\text { Место } \\
\text { работы/учебы } \\
\text { автора доклада }\end{array}$ \\
\hline $10: 00$ & $\begin{array}{c}\text { МАЛЫГИН } \\
\text { Иван Вячеславович }\end{array}$ & $\begin{array}{c}\text { Трехмерная модель юга Фенноскандии по } \\
\text { данным инверсии приемных функций }\end{array}$ & ИФЗ РАН \\
\hline $10: 15$ & $\begin{array}{c}\text { КОРОЛЕВА } \\
\text { Александра } \\
\text { Олеговна }\end{array}$ & $\begin{array}{c}\text { Предварительная интерпретация данных } \\
\text { комплексных исследований на акватории } \\
\text { Баренцева моря в рейсе TTR-20 } \\
\text { (район поднятие Демед) }\end{array}$ & ИФЗ РАН \\
\hline $10: 30$ & $\begin{array}{c}\text { ДАМЯНОВИЧ } \\
\text { Джордже Илиевич }\end{array}$ & $\begin{array}{c}\text { Влияние микроструктуры породы и } \\
\text { затухания упругих волн на подбор } \\
\text { эффетивных параметров в порово- } \\
\text { трещинноватых средах } \\
\end{array}$ & ИФЗ РАН \\
\hline $10: 45$ & $\begin{array}{c}\text { БАХМАЧ } \\
\text { Милана } \\
\text { Михайловна }\end{array}$ & $\begin{array}{c}\text { Расчет индекса хрупкости по результатам } \\
\text { геомеханических испытаний }\end{array}$ & ИФЗ РАН \\
\hline 11:00 & $\begin{array}{c}\text { ВАСИЛЬЕВ } \\
\text { Иван Алексеевич }\end{array}$ & $\begin{array}{c}\text { Влияние внешних факторов на } \\
\text { устойчивость самоподъемной буровой } \\
\text { установки }\end{array}$ & МФТИ \\
\hline $\begin{array}{l}11: 15- \\
11: 30\end{array}$ & \multicolumn{3}{|c|}{ ПЕРЕРЫВ 15 минУт } \\
\hline $11: 30$ & $\begin{array}{l}\text { НАЧЕВ Виктор } \\
\text { Андреевич }\end{array}$ & $\begin{array}{c}\text { Исследование распространения трещин в } \\
\text { сложных породах-коллекторах на } \\
\text { микроуровне }\end{array}$ & ИДГ РАН, МФТИ \\
\hline $11: 45$ & $\begin{array}{c}\text { БОБРОВНИКОВА } \\
\text { Елизавета } \\
\text { Михайловна }\end{array}$ & $\begin{array}{c}\text { Напряженность геомагнитного поля в } \\
\text { конце мелового суперхрона прямой } \\
\text { полярности (по лавовым потокам } \\
\text { Охотско-Чукотского вулканического } \\
\text { пояса) }\end{array}$ & ИФЗ РАН \\
\hline $12: 00$ & $\begin{array}{c}\text { КУЛАКОВА } \\
\text { Екатерина } \\
\text { Петровна }\end{array}$ & $\begin{array}{c}\text { Применение каппаметрии в вопросах } \\
\text { корреляции, стратиграфии и } \\
\text { геохронологии лёссово-почвенных серий } \\
\text { южного Таджикистана }\end{array}$ & ИФЗ РАН \\
\hline $12: 15$ & $\begin{array}{c}\text { КУЗЬМИН } \\
\text { Дмитрий Кузьмич }\end{array}$ & $\begin{array}{c}\text { Сравнительный анализ моделей } \\
\text { формирования локальных напряжений в } \\
\text { зонах раздвиговых разломов } \\
\text { нефтегазоносных регионов }\end{array}$ & ИФЗ РАН \\
\hline $12: 30$ & $\begin{array}{l}\text { ХУСНУТДИНОВ } \\
\text { Фаниль Флерович }\end{array}$ & $\begin{array}{c}\text { Оценка активности естественной } \\
\text { трещиноватости на основе построения 3Д } \\
\text { геомеханической модели нефтяного } \\
\text { месторождения }\end{array}$ & ИФЗ РАН \\
\hline $\begin{array}{l}12: 45- \\
13: 00\end{array}$ & \multicolumn{3}{|c|}{ ПЕРЕРЫВ 15 минУТ } \\
\hline $13: 00$ & $\begin{array}{l}\text { ЛОМОНОСОВ } \\
\text { Михаил } \\
\text { Дмитриевич }\end{array}$ & $\begin{array}{c}\text { Сопоставление результатов измерений } \\
\text { методами спутниковой и наземной } \\
\text { геодезии на одном из нефтегазовых } \\
\text { месторождений Казахстана }\end{array}$ & ИФЗ РАН \\
\hline $13: 15$ & $\begin{array}{l}\text { ПРОХОРЧУК } \\
\text { Александр } \\
\text { Андреевич }\end{array}$ & $\begin{array}{c}\text { Результаты численного моделирования } \\
\text { высотного распределения интенсивности } \\
\text { ионообразования в атмосферном }\end{array}$ & ГО «Борок» \\
\hline
\end{tabular}




\begin{tabular}{|c|c|c|c|}
\hline & & $\begin{array}{c}\text { пограничном слое, производимого гамма- } \\
\text { квантами радионуклидов земной коры }\end{array}$ & \\
\hline $13: 30$ & $\begin{array}{l}\text { КЛИМАНОВА } \\
\text { Екатерина } \\
\text { Вадимовна } \\
\end{array}$ & $\begin{array}{l}\text { Наблюдения электрического состояния } \\
\text { приземной атмосферы и статистические } \\
\text { оценки }\end{array}$ & ГО «Борок» \\
\hline $13: 45$ & $\begin{array}{l}\text { МОЛОКОЕДОВ } \\
\text { Александр } \\
\text { Сергеевич }\end{array}$ & $\begin{array}{l}\text { Скачок напряжений в слоистой } \\
\text { трансверсально-изотропной среде }\end{array}$ & МФТИ \\
\hline $14: 00$ & $\begin{array}{c}\text { КАРЦЕВА Татьяна } \\
\text { Игоревна }\end{array}$ & $\begin{array}{c}\text { Энергетическая классификация } \\
\text { акустических событий по коде сигнала }\end{array}$ & ИФЗ РАН \\
\hline $\begin{array}{l}14: 15- \\
14: 30\end{array}$ & \multicolumn{3}{|c|}{ ПЕРЕРЫВ 15 минУт } \\
\hline $14: 30$ & $\begin{array}{c}\text { МИРОНОВ } \\
\text { Василий } \\
\text { Александрович }\end{array}$ & $\begin{array}{c}\text { Подход к построению региональных } \\
\text { моделей сейсмического эффекта на } \\
\text { примере Байкальского региона }\end{array}$ & $\begin{array}{l}\text { ИВМ СО РАН, } \\
\text { Красноярск }\end{array}$ \\
\hline $14: 45$ & $\begin{array}{c}\text { НЕНЮКОВА } \\
\text { Алёна Игоревна }\end{array}$ & $\begin{array}{c}\text { Нейросетевой прогноз теплопроводности } \\
\text { по данным электромагнитных } \\
\text { зондирований в геотермальной области } \\
\text { Сульц-су-Форе (Франция) }\end{array}$ & ИФЗ РАН \\
\hline $15: 00$ & \multicolumn{3}{|c|}{ ОБЩАЯ ДИСКУССИЯ. ЗАКРЫТИЕ КОНФЕРЕНЦИИ } \\
\hline
\end{tabular}


Оффлайн-секция: 27-28 октября 2021 г.

Видеодоклады доступны по ссылке: https://youtube.com/playlist?list=PLvpWIKEOTji_o4kvFrEKljdeQdvRn4SGU

\begin{tabular}{|c|c|c|}
\hline ФИО докладчика & Название доклада & $\begin{array}{c}\text { Место } \\
\text { работы/учебы } \\
\text { автора доклада }\end{array}$ \\
\hline $\begin{array}{c}\text { АГИБАЛОВ } \\
\text { Алексей Олегович }\end{array}$ & Анализ современной геодинамики Фенноскандии & ИФЗ РАН \\
\hline $\begin{array}{c}\text { АЛЕКСЕЕВ } \\
\text { Роман Сергеевич }\end{array}$ & $\begin{array}{c}\text { Глобальная модель эволюции Гималайско - } \\
\text { Тибетского орогена }\end{array}$ & ИФЗ РАН \\
\hline $\begin{array}{c}\text { АФИНОГЕНОВА } \\
\text { Наталья } \\
\text { Александровна } \\
\end{array}$ & $\begin{array}{c}\text { Результаты применения ферроколлоида для создания } \\
\text { магнитного контраста при микроскопическом } \\
\text { изучении палеомагнитных образцов }\end{array}$ & ГО «Борок» \\
\hline $\begin{array}{c}\text { ГОРДЕЕВ } \\
\text { Никита } \\
\text { Александрович }\end{array}$ & $\begin{array}{c}\text { Новейшее напряженно-деформированное состояние } \\
\text { г.Бештау }\end{array}$ & ИФЗ РАН \\
\hline $\begin{array}{c}\text { ГОРБАТОВ } \\
\text { Евгений Сергеевич }\end{array}$ & $\begin{array}{c}\text { Конволюции в четвертичных озерных комплексах } \\
\text { Балтийского щита и Якутии, и их сравнение с } \\
\text { сейсмитами }\end{array}$ & ИФЗ РАН \\
\hline $\begin{array}{c}\text { ДУДАНОВА } \\
\text { Варвара Ивановна }\end{array}$ & $\begin{array}{c}\text { Опорный разрез позднечетвертичных отложений в } \\
\text { карьере завода им. Свердлова (Ленинградская обл.) - } \\
\text { предварительные результаты полевых работ } 2021 \text { г. }\end{array}$ & МГУ \\
\hline $\begin{array}{c}\text { ЕФРЕМОВ } \\
\text { Иван Вадимович } \\
\end{array}$ & $\begin{array}{c}\text { Pmtools: программное обеспечение для анализа } \\
\text { палеомагнитных данных }\end{array}$ & МГУ \\
\hline $\begin{array}{l}\text { ЗАГОРСКИЙ } \\
\text { Даниил Львович }\end{array}$ & $\begin{array}{c}\text { Результаты верификации спектрального метода } \\
\text { решения обратной задачи сейсмики на численной } \\
\text { модели Мармузи }\end{array}$ & ИФЗ РАН \\
\hline $\begin{array}{c}\text { КОХ } \\
\text { Виктор Витальевич }\end{array}$ & $\begin{array}{c}\text { Многоканальное DAQ устройство длительной } \\
\text { регистрации акустических данных }\end{array}$ & ИФЗ РАН \\
\hline $\begin{array}{c}\text { КОШЕВОЙ } \\
\text { Николай Георгиевич }\end{array}$ & $\begin{array}{c}\text { Изучение новейшей геодинамики и уточнение } \\
\text { глубинного тектонического строения района озера } \\
\text { Маныч-Гудило } \\
\end{array}$ & ИФЗ РАН \\
\hline $\begin{array}{c}\text { ЛЕОНОВА } \\
\text { Анастасия } \\
\text { Михайловна }\end{array}$ & $\begin{array}{c}\text { Исследование начальных этапов деформирования } \\
\text { горных пород с помощью циклических } \\
\text { многостадийных испытаний }\end{array}$ & ИФЗ РАН \\
\hline $\begin{array}{c}\text { ЛИВИНСКИЙ } \\
\text { Артем Игоревич }\end{array}$ & $\begin{array}{c}\text { Характерные геолого-геофизические признаки } \\
\text { рудоносных узлов Кавказа и Алтай-Саянского } \\
\text { региона }\end{array}$ & ИФЗ РАН \\
\hline $\begin{array}{l}\text { МЕЩЕРЯКОВА } \\
\text { Ольга Андреевна }\end{array}$ & $\begin{array}{c}\text { Первые петромагнитные результаты для лёссово- } \\
\text { почвенного разреза Хонако-и (средняя Азия) }\end{array}$ & ИФЗ РАН \\
\hline $\begin{array}{c}\text { МЯГКОВ } \\
\text { Дмитрий Сергеевич }\end{array}$ & $\begin{array}{c}\text { Исследования влияние малых тангенциальных } \\
\text { гравитационных сил на глобальное поле напряжений }\end{array}$ & ИФЗ РАН \\
\hline $\begin{array}{c}\text { СЁМКА } \\
\text { Максим Андреевич }\end{array}$ & $\begin{array}{c}\text { Некоторые особенности зон субдукции в } \\
\text { эпицентральных зонах сильнейших землетрясений } \\
\text { Тихоокеанского пояса } \\
\end{array}$ & ИФЗ РАН \\
\hline $\begin{array}{c}\text { ФУРСОВА } \\
\text { Софья Андреевна }\end{array}$ & $\begin{array}{c}\text { Исследование магнитной текстуры с целью } \\
\text { определения направления течения магмы на примере } \\
\text { разновозрастных даек Мурманского кратона } \\
\text { (Кольский полуостров) }\end{array}$ & МГУ, ИФЗ РАН \\
\hline
\end{tabular}




\title{
Тезисы докладов \\ Научной конференции молодых учёных и аспирантов ИФЗ РАН 27-29 октября 2021 г., ИФЗ РАН, Москва
}

\author{
АНАЛИЗ СОВРЕМЕННОЙ ГЕОДИНАМИКИ ФЕННОСКАНДИИ \\ Агибалов А.О ${ }^{1}$, Сенцов А.А. ${ }^{1}$, Бондарь И.В. ${ }^{2}$ \\ ${ }^{1}$ ИФЗ РАН, Лаборатория методов прогноза землетрясений (702) \\ ${ }^{2}$ ИФЗ РАН, Лаборатория фундаментальныхх и прикладных проблем тектонофизики \\ (204)
}

Для того чтобы проанализировать основные особенности современной геодинамики Фенноскандии, нами проведены комплексные исследования, включающие 1) структурногеоморфологическое дешифрирование цифровой модели рельефа по методике Н.П. Костенко $[1], 2)$ анализ сейсмичности и скоростей современных движений; 3) компьютерное геодинамическое моделирование, рассмотренное в статье [2]; 4) обработку решений фокальных механизмов очагов землетрясений методом катакластического анализа разрывных смещений (МКА) Ю.Л. Ребецкого [3]. Получены следующие основные результаты. 1. Составлена генерализованная схема активных разломов Фенноскандии (достоверных и предполагаемых - выделенных по геоморфологическим признакам). 2. С помощью компьютерного моделирования изучаемая территория разделена на 6 блоков, отличающихся типами напряженного состояния. Показано, что центральная часть Фенноскандии испытывает растяжение, а на периферии преобладают обстановки сдвига и сжатия. Эти особенности согласуются с результатами обработки решений фокальных механизмов очагов землетрясений МКА Ю.Л. Ребецкого и объяснимы развитием территории как сводового поднятия, растущего в условиях слабого горизонтального сжатия. Тектонофизическая модель такого процесса описана в работе [4]. 3. Для большей части изучаемой территории установлена численная корреляция между плотностью эпицентров землетрясений и вероятностью формирования новых разрывов малой протяженности, рассчитанной методом компьютерного моделирования. Она свидетельствует о достоверности предложенных геодинамических моделей и возможности их использования для оконтуривания сейсмически активных участков. 4. По плотности эпицентров сейсмических событий и вероятности формирования новых разрывов малой протяженности выделены 13 зон возможных очагов землетрясений.

Работа выполнена в рамках Государственного задания ИФЗ РАН.

\section{Список литературы:}

1. Костенко Н.П. Геоморфология. М.: МГУ, 1999. 379 с.

2. Сенцов А.А., Агибалов А.О. Выделение зон возможных очагов землетрясений в Фенноскандии по данным анализа сейсмичности и компьютерного геодинамического моделирования // Вестник Московского университета. Серия 4. Геология. 2021. № 1. С. 15-22. 3. Ребецุкий Ю.Л., Сим Л.А., Маринин А.В. От зеркал скольжения к тектоническим напряжениям. Методики и алгоритмы. М.: ГЕОС, 2017. 234 с.

4. Белоусов В.В., Гзовский М.В. Экспериментальная тектоника. М.: Недра, 1964. 120 с.

Докладчик: Агибалов Алексей Олегович, к.г.-м.н., с.н.c., Agibalo@yandex.ru 


\section{ГЛОБАЛЬНАЯ МОДЕЛЬ ЭВОЛЮЦИИ ГИМАЛАЙСКО - ТИБЕТСКОГО ОРОГЕНА Алексеев Р.С., Ребецкий Ю.Л.}

ИФЗ РАН, отделение: разведочной геофизики и прикладной геодинамики, лаб. 204, г. Москва

В работе [1] было показано, что повышенный уровень горизонтального сжатия в континентальных орогенах не связан с дальнодействием напряжений на границах плит, также отмечено, что силу тяги со стороны погруженной и утяжеленной части литосферы, находящейся на глубинах более 100 км стоит рассматривать, как одну из главных причин движения плит. Объединяя эти факторы, а также современные данные о строении и возрасте горных поднятий, полученные в различных исследованиях была создана модель эволюции Гималайско-Тибетского оронена, которая включает в себя несколько важных пунктов. 1) утолщение коры под Тибетом не является результатом давления со стороны Индостанской плиты, а является следствием метаморфических преобразований и выплавок, произошедших в океанической литосфере, погруженной под континент; 2) для образования большого в поперечнике орогена необходим механизм поступления воды, которая является необходимым условием начала преобразований, на большие расстояния; 3) таким механизмом служит ускоренное надвигание Тибета на Индостанскую плиту в результате отрыва палеослэба дальнейшим затягиванием Евразийской платформы во встречном направлении; 4) в результате такого движения образуется слой продавленной океанической литосферы, который выполаживается вдоль подошвы континентальной литосферы и переносит процессы преобразования вещества дальше от будущей зоны коллизии; 5) после отрыва слэба процесс сближения ускоряется, что приводит к меньшим потерям флюида при продвижении океанической литосферы.

\section{Список литературы:}

1. Ребеикий Ю.Л. Поле глобальных коровых напряжений Земли // Геотектоника. 2020. № 6. С. $3-24$. 


\section{РЕЗУЛЬТАТЫ ПРИМЕНЕНИЯ ФЕРРОКОЛЛОИДА ДЛЯ СОЗДАНИЯ МАГНИТНОГО КОНТРАСТА ПРИ МИКРОСКОПИЧЕСКОМ ИЗУЧЕНИИ ПАЛЕОМАГНИТНЫХ ОБРАЗЦОВ}

Цельмович В.А ${ }^{1}$, Афиногенова Н.А. ${ }^{1}$, Бобровникова Е.М., ${ }^{2,3}$, Лебедев И.Е. ${ }^{2,3}$

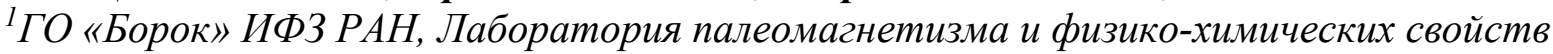
горных пород (ОБ-1)

2 Лаборатория Археомагнетизма и эволюции магнитного поля Земли (106), ИФЗ РАН

${ }^{3}$ Московский государственный университет им. М.В.Ломоносова

Применение магнитных ферроколлоидных жидкостей на образцах, содержащих в своём составе магнитную и немагнитную части, хорошо визуализирует структуру магнитных частиц, а именно: магнетит-ильменитовые сростки, структуры гетерофазного распада, распределение по зерну зон с различной намагниченностью. При больших увеличениях, доступных для оптического микроскопа, диагностируется доменная структура, что позволяет визуализировать саму структуру и определить размеры доменных стенок [1]. Метод применения ферроколлоида позволяет не только быстро диагностировать магнитную структуру зёрен, но и экономить время оператора при последующем изучении образцов при помощи СЭМ.

В течение полевых сезонов 2019 и 2020 годов был опробован ряд разрезов позднемеловых вулканитов Охотско-Чукотского вулканического пояса, изученные материалы принадлежат двум объектам: Купол и объекту Валунистый. Образцы представлены лавами среднего и основного состава (базальтами) с горизонтальным и субгоризонтальным залеганием потоков [2]. В ходе работы были определены размеры, доменная структура, степень окисления титаномагнетитовых зёрен образцов позднемеловых вулканитов ОхотскоЧукотского вулканического пояса, а также их магнитные характеристики. Таким образом, проведенное исследование показало, что титаномагнетиты позднемеловых вулканитов Охотско-Чукотского вулканического пояса характеризуются широким спектром размеров зёрен и неоднородной степенью их состава и окисления, что требует осторожности при интерпретации палеомагнитных результатов, полученных на этой коллекции.

Работа выполнена при поддержке гранта РФФИ №20-05-00215, гранта РФФИ № 19-05-00433, гранта РНФ 19-47-04110.

\section{Сиисок литературы:}

1. $P J W$., $B J C$. Insight into the magnetic mineralogy of Antarctic rocks //Journal of geomagnetism and geoelectricity. - 1967. - T. 19. - №. 3. - C. 195-201.

2. Бельй В. Ф. Стратиграфия и структуры Охотско-Чукотского вулк. пояса. - 1977

Докладчик: Афиногенова Наталья Александровна, м.н.с., aphina312@mail.ru 


\section{РАСЧЕТ ИНДЕКСА ХРУПКОСТИ ПО РЕЗУЛЬТАТАМ ГЕОМЕХАНИЧЕСКИХ ИСПЫТАНИЙ \\ Бахмач М.М., Баюк И.О., Дубиня Н.В.}

ИФЗ РАН, Лаборатория фундаментальных проблем нефтегазовой геофизики и геофизического мониторинга (202)

Термин хрупкость разными авторами используется по-разному. В данной работе проводится анализ двух методов для оценки индекса хрупкости.

Исследование хрупкости и её количественная оценка имеет большое теоретическое и практическое значение в подборе кандидатов для проведения ГРП (гидроразрыва пласта), прогнозировании распределения трещин и проектировании операции ГРП.

Прежде чем приступить к написанию данной работы было проведено ознакомление с источниками литературы, для получения необходимого представления и знания о индексе хрупкости и способах его расчета.

Для расчета индекса хрупкости было выбрано два метода, каждый из которых осуществляется по графику зависимости напряжения от деформации.

По результатам геомеханических исследований были получены данные по 4 образцам скважины Удачной месторождения Дальнего. По полученным значениям были построены графики, по которым была определена хрупкость. Оценка проводилась методом определения хрупкости по проценту упругой деформации и по процентному содержанию обратимой энергии. [1, 2, 3]

Проведённые расчеты в процессе исследования дали результаты, подтверждающие возможность использования данных методов для дальнейшей оценки индекса хрупкости горных пород по лабораторным геомеханическим испытаниям.

\section{Список литературы:}

1. Hucka V; Das. B, Brittleness Determination of Rocks by Different Methods // Int. J. Rock Mech. Min. Sci. \& Geomech. Abstr. Vol. 11. pp. 389-392. Pergamon Press 1974. Printed in Great Britain Brittleness; Society of Exploration Geophysicists: Tulsa. OK. USA. 2012; pp. 1-7.

2. Kim S. Mews, Mustafa M. Alhubail, Reza Gh. Barati; A Review of Brittleness Index Correlations for Unconventional Tight and Ultra-Tight Reservoirs // Geosciences 2019. 9. 319;

3. Rickman. R.; Mullen. M.; Petre. E.; Grieser. B.; Kundert. D. A Practical Use of Shale Petrophysics for Stimulation Design Optimization: All Shale Plays Are Not Clones of the Barnett Shale; Society of Petroleum Engineers: Richardson. TX. USA. 2008.

Докладчик: Бахмач Милана Михайловна, аспирант, milanabm962@gmail.com 


\section{ОСОБЕННОСТИ МОДЕЛИРОВАНИЯ ЭФФЕКТИВНЫХ УПРУГИХ СВОЙСТВ КАРБОНАТНЫХ ПОРОД В МАСШТАБЕ КЕРНА \\ Березина И.А.}

Лаборатория фундаментальных проблем нефтегазовой геофизики и геофизического мониторинга (202), ИФЗ РАН

В данной работе отражены особенности моделирования эффективных упругих свойств карбонатных пород на масштабе керна различными методами теории эффективных сред. Карбонатные породы как правило сильно неоднородны и имеют сложную структуру пустотного пространства. При петроупругом моделировании реальную структуру породу заменяют упрощённым аналогом, который отражает основные черты строения и описывается некоторым набором параметров. На практике существует несколько типов концептуальных моделей карбонатных пород в масштабе керна. Основное отличие этих моделей состоит в том, как пустотное пространство разделяется по типам пористости. Для исследования были взяты три изотропные модели: модель двойной пористости, модель микритового известняка и модель оолитового известняка. Вычисления эффективных модулей произведены следующими методами: метод Кастера-Токсоза [1], самосогласованный метод Берримана [2], метод дифференциальной среды [3] и метод обобщенного сингулярного приближения [4]. Рассмотрены области применимости методов для каждой модели. На основе результатов глобального анализа чувствительности методом Соболя [5] были проведено ранжирование параметров рассматриваемых моделей по степени влияния на дисперсию рассчитываемых упругих модулей в зависимости от выбранного метода, а также уменьшено количество параметров моделей путем фиксирования невлиятельных параметров.

\section{Список литературы:}

1. Kuster G.T., Toksoz M.N. Velocity and attenuation of seismic waves in two-phase media // Geophysics. 1974. issue 39. pp. 587-618.

2. Berryman J.G. Long-wavelength propagation in composite elastic media I Spherical inclusions, II Ellipsoidal inclusions // The Journal of the Acoustical Society of America. 1980. V.68. issue 6. pp. 1820-1831.

3. Norris A.N. A differential scheme for the effective moduli of composites // Mechanics of Materials. 1985. V.4. issue 1. pp. 1-16.

4. Bayuk I. O., Chesnokov E. M. Correlation between elastic and transport properties of porous cracked anisotropic media // Journal of Physics and Chemistry of Solids.1998.Vol. 23. no. 3. P. 361366.

5. Sobol' I. M. Global sensitivity indices for nonlinear mathematical models and their Monte Carlo estimates // Mathematics and Computers in Simulation. 2001. Vol. 55. P. $271-280$.

Докладчик: Березина Ирина Александровна, н.c., iberezina@ifz.ru 
НАПРЯЖЕННОСТЬ ГЕОМАГНИТНОГО ПОЛЯ В КОНЦЕ МЕЛОВОГО

\section{СУПЕРХРОНА ПРЯМОЙ ПОЛЯРНОСТИ (ПО ЛАВОВЫМ ПОТОКАМ ОХОТСКО- ЧУКОТСКОГО ВУЛКАНИЧЕСКОГО ПОЯСА) \\ Бобровникова Е.М. ${ }^{1,2}$, Лебедев И.Е. ${ }^{1,2}$}

${ }^{1}$ Лаборатория Археомагнетизма и эволючии магнитного поля Земли (106), ИФЗ РАН

${ }^{2}$ Московский государственный университет им. М.В. Ломоносова

Изучение взаимосвязи и долгосрочных изменений основных характеристик геомагнитного поля - его геометрии, напряженности и амплитуды вековых геомагнитных вариаций является одним из фундаментальных нерешенных вопросов земного магнетизма. На протяжении геологического времени вплоть до неоархея благодаря многочисленным палеомагнитным исследованиям удалось установить, что частота геомагнитных инверсий изменялась в широких пределах: от периодов в десятки миллионов лет (суперхроны), в течение которых не происходило смен полярности, до периодов, когда частота обращений магнитного поля достигала 7-8 раз за миллион лет [1]. Однако до сих пор однозначная корреляция между стабильностью геомагнитного поля и величиной среднего дипольного момента не выявлена. Обилие низких значений напряженности в течение мезозоя привело к гипотезе «Mesozoic Dipole Low» [3], а определения величины магнитного поля по одиночным силикатным кристаллам [5] и базальтовым стеклам [4] зачастую указывали на то, что в конце мезозоя во время мелового суперхрона прямой полярности величина напряженности была выше современных значений.

Мы представляем новые оценки палеонапряженности, полученные по базальтовым лавам Охотско-Чукотского вулканического пояса (ОЧВП), извергшихся в конце Мелового суперхрона прямой полярности. Результаты получены по 74 лавовым потокам, которые формировались в высоких широтах (80 с.ш.) около 90-84 млн. лет назад, но, к сожалению, лишь небольшая часть определений напряженности удовлетворяет общепринятым критериям качества [2]. Текущие результаты по 8 сайтам демонстрируют изменения величины поля от $27.0 \mu \mathrm{T}$ (количество образцов на сайт $\mathrm{N}=9$, стандартная ошибка $\beta=22.5 \%$ ) до $65.8 \mu \mathrm{T}(\mathrm{N}=11$, $\beta=10.6 \%)$, что не поддерживает, но и не опровергает ни одну из существующих гипотез. Вполне вероятно, полученные значения палеонапряженности по вулканитам ОЧВП могут отражать как изменчивость магнитного поля в конце суперхрона, так и вековой ход величины в высоких северных широтах. Работа выполнена при поддержке РНФ грант № 19-47-04110.

\section{Список литературы:}

1. Павлов В.Э., Галле И. Разработка шкалы магнитной полярности кембрия и ордовика: текущие данные и попытка их синтеза // Физика Земли, 2020, №4, С. 3-28.

2. Biggin, A.J. \& Paterson, G.A., 2014. A new set of qualitative reliability criteria to aid inferences on palaeomagnetic dipole moment variations through geological time, Front. Earth Sci., 2, 1-9, 24.

3. Prevot M., Derder M.M., McWilliams M., Thompson J. Intensity of the Earth's magnetic field: Evidence for a Mesozoic dipole low // Earth Planet. Sci. Lett. 1990. V. 97.P. 129-139.

4. Tauxe L., Staudigel H. Strength of the geomagnetic field in the Cretaceous Normal Superchron: New data from submarine basaltic glass of the Troodos Ophiolite // Geochemistry Geophysics Geosystems. 2004. V. 5. № 2.

5. Tarduno J.A., Cottrell R.D., Smirnov A.V. 2001. High Geomagnetic Intensity During the MidCretaceous from Thellier Analyses of single Plagioclase Crystals // Science.V. 291. P. 1779-1783.

Докладчик: Бобровникова Елизавета Михайловна, инженер, lzbbrvnkv@gmail.com 


\section{РЕЗУЛЬТАТЫ ИССЛЕДОВАНИЙ ДВУХ ЛОКАЛЬНЫХ РАЙОНОВ В ЗОНЕ ВЛИЯНИЯ ИМАНДРА-КОЛВИЦКОГО РАЗЛОМА (КОЛЬСКИЙ ПОЛУОСТРОВ) \\ Бондарь И.В. ${ }^{1}$, Королева А.О. ${ }^{2}$}

${ }^{1}$ ИФЗ РАН, Лаборатория фундаментальных и прикладных проблем тектонофизики (204)

${ }^{2}$ ИФЗ РАН, лаборатория сейсмической опасности (302)

В 2021 году сотрудниками Института физики Земли им. О.Ю.Шмидта РАН и Института Географии РАН были проведены полевые исследования двух локальных районов в зоне влияния Имандра-Колвицкого разлома. Данный разлом имеет северо-западное простирание, длину более 100 км и протягивается от северного берега Кандалакшского залива в районе Лувеньгских тундр до южного берега озера Экостровская Имандра. По данным [1] в пределах этой структуры встречаются следы сейсмической активности - сейсмотектонические и сейсмогравитационные проявления, характерные для землетрясений интенсивностью IX+ баллов.

В ходе полевых работ были исследованы два локальных района: гора Оспе и побережье о3. Средняя Лувеньга. В первую очередь была проведена съемка квадрокоптером, также изучались коренные выходы пород, собиралась информация о пространственной ориентировке геологических стресс-индикаторов.

Съемка осуществлялась квадрокоптером DJI Mavic Pro с высоты 300-500 м над уровнем моря. Далее фотографии были обработаны и объединены в ортофотопланы местности, построенные при помощи ПО Agisoft PhotoScan Professional. Следующим этапом было построение карт высот (цифровых моделей местности) и полигональных моделей, которые позволяли более наглядно изучить строение исследуемых объектов.

В районе г. Оспе структурно-геоморфологическим методом Сим Л.А. проанализировано предположительное разрывное нарушение меридионального простирания. По ортофотоплану отдешифрирована трещиноватость и определено, что смещение по разрыву имеет левосдвиговую кинематику. Это подтверждается и обнаруженными зеркалами скольжения в бортах разрыва.

В районе оз. Средняя Лувеньга собран материал о пространственной ориентировке геологических стресс-индикаторов. Первичная его обработка позволяет выделить два этапа деформирования с ориентировками осей максимального сжатия в северо-западном и северовосточном направлениях. Однако, определить, относится ли это непосредственно к разлому или к его оперяющим структурам, пока затруднительно.

Благодарности. Авторы выражают благодарность заведующему лаборатории геоморфологии ИГ РАН Швареву С.В. за организацию полевых работ. Работы выполнены в рамках Госзадания ИФЗ РАН по теме НИР 0144-2019-0010.

\section{Список литературы:}

1. Шварев С.В., Николаева С.Б., Королева А.О. Морфологические проявления постледниковой сейсмической активности Имандра-Колвицкого активного разлома в Лувеньгской очаговой зоне (Мурманская область) // Труды Ферсмановской научной сессии ГИ КНЦ РАН. 2021. 18. C. 425-429 - DOI: 10.31241/FNS.2021.18.080

Докладчик: Бондарь Иван Владимирович, н.c., bond@, ifz.ru 
ВЛИЯНИЕ ВНЕШНИХ ФАКТОРОВ НА УСТОЙЧИВОСТЬ САМОПОДЬЕМНОЙ БУРОВОЙ УСТАНОВКИ

Васильев И.А. ${ }^{1}$, Дубиня Н.В. ${ }^{1,2}$ Начев В.А. ${ }^{1,3}$, Алексеев Д. А. ${ }^{1}$, Тихоцкий С.А. ${ }^{1,2}$

${ }^{1}$ Московский физико-технический институт;

${ }^{2}$ Институт физики Земли им. О.Ю. Шмидта Российской Академии наук

${ }^{3}$ Институт динамики геосфер имени академика М.А. Садовского

Российской академии наук (ИДГ РАН)

Задачей исследования является анализ влияния внешних факторов на устойчивость самоподъемной буровой установки (СПБУ) при освоении углеводородов на шельфе. Основные подходы к проектированию и использованию которых были сформулированы сравнительно давно [1].

Несмотря на то, что методы изучения механических свойств продолжают активно развиваться [2], актуальными остаются вопросы точности в определении механических свойств верхних слоев донных отложений, необходимой для получения достоверных оценок рисков эксплуатации объектов инфраструктуры на шельфе.

В работе приведен пример полноценного моделирования механического поведения СПБУ с целью прогноза рисков при ее эксплуатации. В качестве частной задачи рассмотрено поведение СПБУ и донных грунтов, на которых она установлена, при сейсмических воздействиях. По результатам численного моделирования были определены пространственные распределения полей напряжений и деформаций в самой СПБУ и в окрестности опорных колонн. Было рассмотрено равновесное напряженнодеформированное состояние среды, обусловленное собственным весом СПБУ и сопротивлением грунтов, а также его возмущение, вызванное приходом поверхностной сейсмической волны от крупного землетрясения. В результате анализа рассчитанных полей напряжений были определены зоны их локализации в колоннах СПБУ и определены наиболее опасные с точки зрения потери устойчивости области. Кроме того, было исследовано влияние механических свойств грунтов на критические значения параметров, характеризующих сейсмический сигнал: в частности, была определена зависимость амплитуды волны, приводящей к превышению предела прочности материала колонн и их последующему разрушению, от статических упругих модулей грунта.

В настоящее время идет более детальная проработка модели: однородная среда донных отложений заменена на многослойную, некоторым слоям заданы характеристики, присущие пористым средам.

Полученные результаты позволили сформулировать алгоритм для прогноза сейсмической опасности при бурении на шельфе, основанный на численном моделировании механических процессов на конкретных объектах.

\section{Сиисок литературы:}

1. Агагусейнов, Ю.А., Вишневская Э.Л., Кулиев И.П., Лейбензон С.Р., Марилок А.Б., Мочалов М.Н., Саркисов В.Г. Самоподъемные плавучие буровые установки М., Недра, $1979,215 \mathrm{c}$.

2. Тихоцкий С.А., Дубиня Н.В., Начев В.А. Новый подход к оценке физико-механических свойств донных отложений в ходе проведения пробоотбора // Доклады Российской академии наук. Науки о Земле. 2020. Т. 495. № 2. С. 18-22.

Докладчик: Васильев Иван Алексеевич, студент, vasilev.ivan@phystech.edu 


\section{КОНВОЛЮЦИИ В ЧЕТВЕРТИЧНЫХ ОЗЕРНЫХ КОМПЛЕКСАХ БАЛТИЙСКОГО ЩИТА И ЯКУТИИ, И ИХ СРАВНЕНИЕ С СЕЙСМИТАМИ \\ Горбатов E.C.}

ИФЗ РАН, Лаборатория палеосейсмологии и палеогеодинамики (304)

Проведено сравнение складок разжижения (конволюций) в озерных осадках Балтийского щита и Северной Якутии с сейсмитами Тянь-Шаня с целью уточнения происхождения этих структур в первых двух регионах. Показано, что конволюции сравниваемых регионов существенно отличаются по составу осадков и степени их разжижаемости, вертикальному градиенту их плотности и вязкости при деформации, что предполагает разный генезис данных структур. При оценке разжижаемости дисперсных осадков учитывалось, что фракции с размером зерен 0.01-1 мм (от алеврита до крупнозернистого песка) относятся к разжижаемым, тогда как осадки остальных фракций (глина, гравий, галька) - к сравнительно слабо разжижаемым [1]. Для анализа вертикального градиента плотности сравнивался гранулометрический состав стратифицированных осадков. Учитывалось, что системы «крупнозернистые осадки на мелкозернистых» обычно обладают неустойчивой стратификацией по плотности, а при обратном порядке слоев - устойчивой стратификацией. Для оценки вертикального градиента вязкости рассмотрено соотношение ширины син- и антиклинальных складок в горизонте конволюций $\left(K_{C}\right)$, при котором $K_{C}>1$ соответствует нормальному вертикальному градиенту вязкости, а $K_{C}<1-$ его инверсии [2]. Конволюции Балтийского щита и отчасти Якутии отмечены в наиболее разжижаемых осадках с неустойчивой плотностной стратификацией (пески-на-алевритах), что говорит об их самопроизвольном образовании при литогенезе [2, 3]. На Тянь-Шане в деформацию вовлекались зачастую слабо разжижаемые грубообломочные осадки, а конволюции формировались при устойчивой стратификации осадков по плотности (илы-на-песках) и в условиях инверсии вязкости. Эти признаки однозначно указывают на сейсмическую инициацию процессов разжижения. Полученные результаты обосновывают литогенный генезис конволюций в озерных комплексах Балтийского щита, литогенный и криогенный Якутии и сейсмогенный - Тянь-Шаня. Для диагностики генезиса конволюций предложено определять региональный разброс значений $K_{C}$, который для литогенных структур смещен в область с $K_{C}>1$, а для сейсмитов - сравнительно симметричен относительно $K_{C}=1$. Полученные результаты расширяют и дополняют методы выявления сейсмитов в осадочных комплексах, позволяя выделять их на фоне широко распространенных литогенных и криогенных деформационных структур.

\section{Сиисок литературы:}

1. Obermeier S.F. Using Liquefaction-Induced and Other Soft-Sediment Features for Paleoseismic Analysis // Paleoseismology. San Diego: Academic Press, 1996. P. 497-564.

2. Горбатов Е.С., Колесников С.Ф., Корженков А.М., Варданян А.А. Структурнолитологическое сравнение конволюций в озерных комплексах $\left(\mathrm{Q}_{3-4}\right)$ Балтийского щита, северной Якутии, Тянь-Шаня // Вопросы инженерной сейсмологии. 2021. Т. 48. № 3. С. 41-59. 3. Горбатов E.C. Особенности формирования кама «Шарваозеро» (Северная Карелия) и сингенетических деформаций в его разрезе // Геофизические процессы и биосфера, 2020. № 3. C. 33-50.

Докладчик: Горбатов Евгений Сергеевич, к.г-м.н., с.н.c., e.s.gor@mail.ru 
НОВЕЙШЕЕ НАПРЯЖЕННО-ДЕФОРМИРОВАННОЕ СОСТОЯНИЕ Г.БЕШТАУ

Гордеев Н.А., Бондарь И. В.

${ }^{1}$ ИФЗ РАН, Лаборатория фундаментальных и прикладных проблем тектонофизики (204)

Зафиксированные обстановки горизонтального растяжения по периферии интрузии, а также пространственная ориентировка сбросовых зеркал скольжения возможно связаны с новейшим развитием массива горы Бештау - поднятием в центральной части и разгрузкой избыточных горизонтальных напряжений к краям массива. Помимо этого подчеркнута активность разломных зон, что говорит о повышенной потенциальной угрозе разгрузки радиоактивных подземных вод и газов (радон).

Анализом трещиноватости выявлено [1] кольцевое оседание массива, подчеркнуты две системы разрывов, сквозная северо-восточного простирания, проходящая через весь массив и субмеридиональная, приуроченная к восточной части массива. Обнаружены две интесивно растресканные области в точках KMV 4/19, 3/19. Эти точки лежат на пересечении региональных разрывных систем. Точка KMV 4/19 на пересечении субмеридиональной системы и системы, приуроченной жилам «Скала». Точка KMV 3/19 на пересечении субмеридиональной системы и системы «Лохматый курган».

На основании полученных результатов более полного изучения радоновых аномалий можно будет спрогнозировать пути миграции подземных вод, зараженных радиоактивными элементами, что важно для населения расположенных рядом с горой Бештау городов.

Также стоит отметить, что для более полного изучения геодинамики горы Бештаугорского массива, требуется доизучение его центральной и восточной части.

Исследования выполнены при финансовой поддержке РФФИ (грант № 18-05-00674а), часть исследований выполнялась в рамках государственного задания Министерства науки и высшего образования РФ № АААА-А19-119021190076-9 (ИГЭ РАН) $и$ в рамках государственного задания ИФЗ РАН.

Список литературы:

1. Микляев П.С., Суханова Т.В., Петрова Т.Б. и др. Новейшая тектоника и геодинамика поднятия Бештаугорского массива (Кавказские Минеральные Воды) // Пятая тектонофизическая конференция в ИФЗ РАН. “Тектонофизика и актуальные вопросы наук о Земле”. М. 2020. С. 261-267.

Докладчик: Гордеев Никита Александрович, н.c., gord@ifz.ru 
МАССИВ СИНХРОННЫХ МТ/МВ ЗОНДИРОВАНИЙ ЕАRТНSСОРЕ:

МНОГОТОЧЕЧНОЕ ОЦЕНИВАНИЕ И АНАЛИЗ ПЕРЕДАТОЧНЫХ ОПЕРАТОРОВ В АКТИВНОМ РЕГИОНЕ СЕВЕРО-ЗАПАДА США

Грачева Д.А., Варенцов Ив.М., Лозовский И.Н.

Центр геоэлектрических исследований - филиал ИФЗ РАН им. И.О. Шмидта

В докладе представлены результаты обработки данных массива синхронных магнитотеллурических (МТ) и магнитовариационных (MB) зондирований программы EarthScope с использованием разработанной в ЦГЭМИ ИФЗ РАН программной системы PRC_MTMV $[1,2]$.

EarthScope является многолетней национальной программой США по изучению глубинного строения и динамики континента Северной Америки [3]. В ее рамках реализуется проект EMScope площадных синхронных MT и MB зондирований с целью изучения геоэлектрической структуры континентальной тектоносферы.

Основными задачами первого этапа наших исследований являлись апробация разработанных в ЦГЭМИ ИФЗ РАН методов обработки синхронных МТ/МВ данных в сопоставлении с имеющимися американскими результатами на массивах данных, полученных с применением новой аппаратуры, получение оригинальных оценок горизонтальных МВ откликов, отсутствующих у американской стороны, и подготовка массива данных для дальнейшей сводной 3D интерпретации совокупности МВ откликов (горизонтальных и типпера) с применением методов 3D инверсии.

Примененная методика мульти-RR оценивания импеданса и типпера, основанная на робастном осреднении одноточечных (single-site, SS) и серии двухточечных (remote reference, RR) оценок, полученных для различных удаленных пунктов, позволила получить надежные оценки импеданса и типпера, превосходящие по качеству имеющиеся результаты американской синхронной обработки [3].

Важнейшим результатом исследований является успешное опробование наших технологий оценивания горизонтальных МВ откликов в пределах синхронных кластеров зондирований, интеграции оценок для серии кластеров в единые массивы с опорой на данные геомагнитных обсерваторий и пересчет этих массивов к интерпретационной базе, удаленной от геоэлектрических аномалий. В ходе работы были построены карты важнейших инвариантов МВ данных, которые позволили выделить ряд глубинных проводящих структур, имеющих 3D структуры.

Работа выполнена при поддержке РФФИ (грант № 18-35-00598_мол_а) и в рамках темы госзадания ЦГЭМИ ИФЗ РАН №0144-2019-0021.

\section{Список литературы:}

1. Варенцов Ив.М., Соколова Е.Ю., Мартанус Е.Р. и др. Методика построения передаточных операторов ЭМ поля для массива синхронных зондирований BEAR // Физика Земли. 2003. № 2. С. 30-61.

2. Varentsov Iv.M. Arrays of simultaneous EM soundings: design, data processing, analysis, and inversion // EM Sounding of the Earth's Interior, V. 40 ( $2^{\text {nd }}$ Edition). Amsterdam: Elsevier. 2015. P. 271-299.

3. Kelbert A., Erofeeva S., Trabant C. et al. Taking MT data out of the drawer// Eos. 2018. V. 99. doi:10.1029/2018EO112859

Докладчик: Грачева Дарья Алексеевна, н.c., mckoreneva@mail.ru 


\section{ИССЛЕДОВАНИЕ СЕЙСМОТЕКТОНИЧЕСКИХ ДЕФОРМАЦИЙ О. САХАЛИН ПО ДАННЫМ СПУТНИКОВОЙ ГЕОДЕЗИИ Гридчина М.С., 2}

${ }^{1}$ ИФЗ РАН Лаборатория спутниковых методов изучения геофизических проиессов (203)

${ }^{2}$ ФГБУ «Центр геодезии, картографии и ИПД»

Как известно, локальные скорости смещения пунктов вблизи границ блоков могут заметно отличаться от оценок, вытекающих из существующих геолого-геодезических моделей вращения плит, поэтому необходимо изучение местной геодинамики сейсмоактивных районов вдоль межблоковых границ. Наряду с чисто научным интересом, этот вопрос имеет и практическую значимость. Помимо опасности проявлений сейсмической активности для людей, живущих на территории острова, эти явления могут послужить препятствием для нормального функционирования многих ответственных линейных инженерных сооружений или вовсе сыграть для них разрушительную роль. Кроме того, геодинамику региона необходимо знать для построения местных систем координат.

Темой данной работы является изучение геодинамики о. Сахалин. Исследования сейсмотектонических деформаций этого региона проводились и ранее, например, в работе [1]. Однако тогда использовался сравнительно небольшой объём доступных данных. Настоящее исследование, в отличие от предшествующих, основано на новых, ранее не использованных материалах, полученных в результате многолетних ГНСС измерений на Сахалинском геодинамическом полигоне ФГБУ «Центра геодезии, картографии и ИПД».

По новым временным рядам координат наблюдательных пунктов получены оценки скоростей поверхностных смещений, которые отражают подвижность разломов, простирающихся вдоль всего острова. В дальнейшем планируется исследовать глубинное распределение современных движений вдоль разломов в зоне сочленения Амурской и Охотоморской плит на о. Сахалин.

\section{Сиисок литературы:}

1. Kogan M.G., Bürgmann R., Vasilenko N.F., Scholz C.H., King R.W., Ivashchenko A.I., FrolovD.I., Steblov G.M., Kim Ch.U., Egorov S.G. The $2000 \mathrm{M}_{\mathrm{w}} 6.8$ Uglegorsk earthquake and regional plate boundary deformation of Sakhalin from geodetic data // Geophisical research letters, vol. 30, no. 3, 1102, doi:10.1029/2002GL016399, 2003.

Докладчик: Гридчина Мария Сергеевна, аспирант, gridchina.maria@mail.ru 
ВЛИЯНИЕ МИКРОСТРУКТУРЫ ПОРОДЫ И ЗАТУХАНИЯ УПРУГИХ ВОЛН НА ПОДБОР ЭФФЕТИВНЫХ ПАРАМЕТРОВ В ПОРОВО-ТРЕЩИННОВАТЫХ СРЕДАХ

\section{Дамянович Д.И.}

Институт физики Земли им. О.Ю. Шмидта Российской Академии наук

В настоящее время для оценки эффективных упругих свойств пород применяется петроупругое моделирование. Однако в ряде случаев затухание может оказывать существенное влияние на подбор петроупругих параметров породы, так как из класса упругих моделей среда переходит к вязкоупругим, учитывающим и реологические эффекты. В связи с этим оценка затухания упругих волн в порово-трещиноватых средах имеет важное значение для правильного подбора модели эффективной среды.

Для петроупругого моделирования эффективных упругих свойств пород доманиковой свиты использовался метод самосогласования Берримана для N компонент [1]. На нулевой итерации в качестве начальной модели использовались упругие модули, посчитанные по верхней границе Хашина-Штрикмана [2]. Кварц рассматривался в виде сферических включений, а кероген оценивался и в виде отдельных включений, и в составе эффективной матрицы. Дополнительно исследовалось влияние узких трещин с аспектным отношением от 0,001 до 0,1 на подбор эффективных упругих свойств.

В ходе петроупругого моделирование выяснилось, что кероген нецелесообразно рассматривать как отдельные включения, так как значения упругих модулей получаются завышенными. При этом добавление керогена в эффективную матрицу слабо снижают значения последних. Однако добавление узких трещин с аспетным отношением 0,01 резко снижает значения упругих модулей, причём при увеличении трещиноватости модуль сдвига уменьшается сильнее, чем модуль всестороннего сжатия. В то же время изменение аспектного отношения сильнее влияет на модуль всестороннего сжатия.

В дальнейшем осуществлялся переход от петроупругого к вязкоупругому моделированию. Согласно теореме Хашина, задачу подбора вязкоупругих модулей можно решить в рамках теории эффективных сред, заменив упругие модули на комплексные вязкоупругие. На первом этапе было проведено прямое моделирование влияния затухания на вязкоупругие модули. Модуль сдвига и, как следствие, скорости поперечных волн практически не реагируют на затухание. В то же время модуль всестороннего сжатия, рассчитанный по нижней границе Хашина-Штрикмана, резко увеличивается в диапазоне коэффициента затухания от 0 до 20, а затем характер роста функции меняется на более пологий. Для проверки результатов прямого моделирования производилась оценка затухания упругих волн непосредственно из волновых форм методами спектральных отношений и сдвига пиковой частоты. Последний метод удалось применить далеко не во всех случаях, так как на спектрах практически не наблюдается сдвига пиковой частоты. В то же время коэффициент затухания, определённый по наклону логарифма отношения спектров и в точке локального максимума, подтверждает расчётные параметры (коэффициент затухания, полученный из прямого моделирования, - 0,106, в точке локального максимума - 0,081, оценка через наклон - 0,078).

\section{Список литературы:}

1. Berryman, J.G., Mixture theories for rock properties. In Rock Physics and Phase Relations: a Handbook of Physical Constants, ed. T.J. Ahrens. Washington, DC: American Geophysical Union, 1995. pp. 205-228.

2. Hashin Z., Shtrikman S. Avariational approach to the elastic behavior of multiphase materials // J. Mech. Phys. Solids. 1963. V. 11. P. 127-140.

Докладчик: Дамянович Джордже Илиевич, аспирант, damjanov@mail.ru 
ОПОРНЫЙ РАЗРЕЗ ПОЗДНЕЧЕТВЕРТИЧНЫХ ОТЛОЖЕНИЙ В КАРЬЕРЕ

ЗАВОДА ИМ. СВЕРДЛОВА (ЛЕНИНГРАДСКАЯ ОБЛ.) - ПРЕДВАРИТЕЛЬНЫЕ РЕЗУЛЬТАТЫ ПОЛЕВЫХ РАБОТ 2021 Г. Дуданова В.И. ${ }^{1,2}$, Ручкин М.В. ${ }^{2,3}$

${ }^{1}$ Московский государственный университет им. М.В. Ломоносова

${ }^{2}$ ФГБУ «Всероссийский научно-исследовательский геологический институт им. А.П. Карпинского, Санкт-Петербург

${ }^{3}$ Санкт-Петербургский государственный университет, Санкт-Петербург

Приневская низменность - классический район, на изучении которого сложились основные представления о стратиграфии и геохронологии квартера северо-запада России. При геологосъемочных работах во второй половине XX в. здесь в ряде скважин была вскрыта сложно построенная толща, в которой представлена почти непрерывная последовательность четвертичных отложений конца среднего - середины/конца позднего неоплейстоцена [1].

Один из немногих и, видимо, самый полный непрерывный разрез позднемосковских - средневалдайских (?) отложений, который доступен для изучения непосредственно в обнажениях, находится на правом берегу р. Нева в карьере Завода им. Свердлова. Этот разрез венчают позднеледниковые ленточные глины, в которых И.И. Красновым была изучена первая в Ленинградском регионе палеомагнитная запись [2].

В ходе полевых работ 2021 г. нами был описан разрез, в котором представлены позднемосковский гляциолимний $(\lg I \mathrm{Ims})$, мгинский мариний $(\mathrm{mIIImk})$ - серые и черные, иногда битуминозные глины с растительным детритом, перекрытые нижне- или средневалдайским лимнием (IIIIvd 1-2?), осташковским тиллом (gIIIos) и гляциолимнием Балтийского ледникового озера $(\operatorname{lgIII} b l)$ - ленточно-слоистым переслаиванием глин и алевритов, которые слагают площадку озерно-ледниковой террасы высотой 12-13 м абс.

Из позднемосковских, мгинских и позднеледниковых отложений были отобраны 98 ориентированных образцов для палеомагнитных исследований, 66 образцов на спорово-пыльцевой анализ и 25 образцов для ОСЛ-датирования в целях установления стратиграфического положения и абсолютного возраста экскурса обратной полярности Блейк (Сероглазка), который приходится на время максимума мгинской трансгрессии в оптимум микулинского межледниковья, а также для получения геохронологической и палеомагнитной характеристик позднеледниковых отложений. Кроме того, в позднеледниковых отложениях проведен подсчет годовых лент для привязки варвохронологической шкалы Приневья к Шведской и Финской шкалам.

\section{Список литературы:}

1. Селиванов В.А., Недригайлова И.С. Государственная геологическая карта СССР. Масштаб 1:200 000. Серия Ильменская. Лист О-36-I. Объяснительная записка. Л., 1963, $280 \mathrm{c}$.

2. Путеводитель экскурсий А-15, С-15. Ленинград и Ленинградская область. ХІ конгресс ИНКВА. М., 1982, 10 с.

Докладчик: Дуданова Варвара Ивановна, магистрант, varyanich1212@gmail.com 
PMTOOLS: ПРОГРАММНОЕ ОБЕСПЕЧЕНИЕ ДЛЯ АНАЛИЗА

ПАЛЕОМАГНИТНЫХ ДАННЫХ

Ефремов И.В. ${ }^{1}$ Веселовский Р.В. ${ }^{1,2}$

${ }^{1}$ Московский государственный университет им. М. В. Ломоносова

${ }^{2}$ ИФЗ РАН, Лаборатория Археомагнетизма и эволюччи магнитного поля Земли (106)

PMTools - программное обеспечение, призванное упростить и ускорить процесс анализа палеомагнитных данных, написанное с использованием современных технологий и рассчитанное на максимальное удобство использования.

B PMTools peализован полный цикл палеомагнитных операций, в частности: выделение компонент естественной остаточной намагниченности, статистика палеомагнитных направлений, вычисление виртуальных геомагнитных полюсов, а также имеется возможность выполнения статистических тестов. Программа PMTools создавалась с учётом опыта использования уже привычных отечественным палеомагнитологам программ, при этом основная идея бралась из взаимодействия пользователя с пакетом программ для анализа палеомагнитных данных, написанным Рэндольфом Энкиным [Enkin, 1994]. В частности, PMTools полностью наследует управление посредством горячих клавиш и в целом доступна для полноценного использования с помощью клавиатуры. При этом интерфейс программы создан в соответствии с современными стандартами, а вся графическая информация, получаемая в ходе обработки данных в PMTools, может быть экспортирована как в растровом, так и в векторном формате, будучи максимально адаптированной для мгновенного использования в качестве материалов публикаций или в презентациях.

Мы представляем первую рабочую версию PMTools, которую можно скачать по адресу: https://github.com/I194/PMTools/releases. В докладе будут отмечены отличительные особенности программы от её ближайших конкурентов, а также озвучены планы дальнейшего развития.

\section{Сиисок литературы:}

1. Enkin, R. J.: A computer program package for analysis and presentation of paleomagnetic data // Pacific Geoscience Centre, Geological Survey of Canada, 1994.

Докладчик: Ефремов Иван Вадимович, студент, i1948374@yandex.ru 
О СОТРУДНИЧЕСТВЕ ИНСТИТУТА ФИЗИКИ ЗЕМЛИ ИМ. О.Ю. ШМИДТА

РОССИЙСКОЙ АКАДЕМИИ НАУК И РУССКОГО ГЕОГРАФИЧЕСКОГО

ОБЩЕСТВА В 2020 И 2021 ГОДАХ

Жостков Р.А. ${ }^{1}$, Овсюченко А.Н. ${ }^{2}$

${ }^{1}$ ИФЗ РАН, Лаборатория фундаментальных проблем экологической геофизики и вулканологии (703)

${ }^{2}$ ИФЗ РАН, Лаборатория сейсмотектоники и сейсмического микрорайонирования (701)

В 2020 году сотрудники Института физики Земли им. О.Ю. Шмидта Российской академии наук приняли участие в Комплексной экспедиции Северного флота и Русского географического общества на арктических архипелагах. Экспедиция проходила на ледоколе «Илья Муромец» в течение почти четырех месяцев, за которые было пройдено более 20.000 км по акватории восьми морей Северного-Ледовитого, Атлантического и Тихого океанов. Было посещено 33 объекта, на 20-ти из которых проводились геологогеофизические работы, включавшие геолого-морфологическое картирование, отбор геологических проб, аэрофотосъемка с использованием квадрокоптера для построения ортофотоплана и цифровой модели рельефа, георадарные исследования, микросейсмические измерения и микросейсмическое зондирование (последнее было проведено в трех районах). Эти исследования позволили по-новому взглянуть на сейсмичность Арктики, поскольку повсеместно были найдены следы сильных землетрясений в прошлом, что свидетельствует об их возможном повторении в будущем. Некоторые результаты уже опубликованы [1], другие же готовятся к публикации. Помимо научной ценности стоит отметить разработку и апробацию методики проведения полевых работ в столь экзотических условиях, главная трудность которых крайне малое время, выделенное на проведение работ (всего несколько часов на объект).

В 2021 году сотрудничество РГО и ИФЗ РАН расширилось. Так, например, авторы приняли участие в экспедиции на Землю Франца-Иосифа, где обследовали о. Александры и выполнили самое крупное микросейсмическое зондирование в регионе, в том числе профильное исследование через бухту Северную по ледовому покрову в рамках разрабатываемой технологии мониторинга арктических морей [2].

Также в 2021 году было запланировано две совместные экспедиции на архипелаг Новая Земля, но из-за трудностей с подготовкой судна эти экспедиции было решено перенести на 2022 год. Тем не менее сотрудниками ИФЗ РАН удалось принять участие в экспедиции РГО на Курильские острова.

Таким образом партнерство ИФЗ РАН и РГО стремительно развивается и все большее число научных работников может принять участие в организуемых экспедициях. Сегодня между ИФЗ РАН и РГО заключен договор о сотрудничестве, который при решительных действиях обеих сторон позволит добиться новых и интересных научных результатов о самых отдаленных и малоизученных уголках нашей страны.

\section{Сиисок литературы:}

1. Овсюченко А.Н., Собисевич А.Л., Ляменков М.В., Жостков Р.А. Новые данные о сильных землетрясениях в Арктической зоне Российской Федерации по результатам геологогеофизических исследований на о. Белуха // Доклады академии наук. 2021. № 1. С. 60-64.

2. Преснов Д.А., Жостков Р.А., Собисевич А.Л., Шуруп А.С. Натурные наблюдения сейсмоакустических волн в условиях покрытого льдом водоема // Известия Российской академии наук. Серия физическая. 2017. Т. 81. № 1. С. 76-80.

Докладчик: Жостков Руслан Александрович, к.ф.-м.н., с.н.с., shageraxcom@yandex.ru 


\section{РЕЗУЛЬТАТЫ ВЕРИФИКАЦИИ СПЕКТРАЛЬНОГО МЕТОДА РЕШЕНИЯ ОБРАТНОЙ ЗАДАЧИ СЕЙСМИКИ НА ЧИСЛЕННОЙ МОДЕЛИ МАРМУЗИ Загорский Д.Л. ${ }^{1,2}$, Преснов Д. А ${ }^{1}$, Жостков Р. А. ${ }^{1}$}

${ }^{1}$ ИФЗ РАН, Лаборатория фундаментальных проблем экологической геофизики и вулканологии (703)

Достоверность решения обратной задачи зависит от того, насколько адекватно выбрана опорная модель. Математическая теория обратных спектральных задач позволяет находить решение напрямую, используя математический аппарат почтипериодических функций [1]. При этом отсутствует необходимость знания всей опорной модели среды, нужно только лишь знание параметров среды вблизи дневной поверхности - фазовых скоростей волн Рэлея. [2]

В настоящей работе рассматривается один из эффективных методов решения математической спектральной обратной задачи, обсуждается возможность его применения для восстановления скоростной модели среды.

На основе теоретически обоснованных математических алгоритмов, данных выполненного численного моделирования на примере геофизической модели Мармузи [3] демонстрируется возможность анализа высокочастотной составляющей шума для восстановления малоглубинного сейсмического разреза. Приведено краткое описание алгоритма инверсии и результаты вычислений в виде скоростной модели поперечных волн. Показано удовлетворительное совпадение модели и результатов инверсии на глубинах до 100 м.

\section{Сиисок литературы:}

1. Седипков А.А. Обратная спектральная задача для оператора Штурма- Лиувилля с разрывным потенциалом // Препринт - 277. ИМ СОРАН. - 2012. - С. 26.

2. Загорский Л.С. Анализ поля волн типа Лява при решении обратной спектральной задачи определения строения среды. //ИГД им. А.А. Скочинского. - М., 1994. - Деп. в ЦНИЭИуголь 25.02.94 N 5448.- 5 с.

3. Versteeg R. The Marmousi experience: velocity model determination on a synthetic complex data set // The Leading Edge. 1994. Vol. 13. P. 927-936.

Докладчик: Загорский Даниил Львович, аспирант, daniil@,ifz.ru 


\section{ПРИМЕНЕНИЕ БЕСПИЛОТНЫХ ЛЕТАТЕЛЬНЫХ АППАРАТОВ В УСЛОВИЯХ ПОЛЕВЫХ ГЕОЛОГИЧЕСКИХ РАБОТ}

Холодков К.И. ${ }^{1}$, Иванов С.Д. ${ }^{1}$, Корягин В.Н. ${ }^{1}$, Алешин И.М. ${ }^{1}$, Холодков И.Н. ${ }^{1}$, Морозов Ю.А. ${ }^{2}$, Матвеев М.A. ${ }^{2}$

${ }^{1}$ ИФЗ РАН, Лаборатория геоинформатики (501)

${ }^{2}$ ИФЗ РАН, Лаборатория тектоники и геодинамики (103)

Сравнительно недавно получившие широкое распространение беспилотные летательные аппараты (БПЛА) являются, в частности, перспективными инструментами, открывающими новые возможности в науках о Земле [1]. В ходе полевых сезонов 2020 и 2021 годов группа сотрудников лаборатории 501 ИФЗ РАН была прикомандирована к Ладожскому тектоническому отряду ИФЗ РАН по руководством чл.-корр. РАН Ю.А. Морозова, где получила возможность приобрести практический опыт использования БПЛА в условиях полевых геологических работ на северном побережье Ладожского озера. Летательные аппараты были оснащены не только типичными для данного класса устройств фотокамерами, но и высокоточными GPS приемником [2] и лидаром. Была выполнена магнитная съемка двух объектов с использованием протонного магнитометра GEM Systems и подготовительные работы для использования компактного магнитометра Drotek RM3100.

Работа выполнена в рамках тем государственного задания ИФЗ РАН, номер государственной регистраџии ААAA-А19-119110500109-0.

\section{Сиисок литературы:}

1. Aleshin I.M., Ivanov S.D., Koryagin V.N., Matveev M.A., Morozov Yu A., Perederin F.V., Kholodkov K.I. Review on the Use of Light Unmanned Aerial Vehicles in Geological and Geophysical Research // Seismic Instruments. Vol. 56. № 5. p. 509-515.

2. Perederin F.V., Aleshin I.M., Ivanov S.D., Mikhailov P.S., Pogorelov V.V., Kholodkov K.I. Portable GNSS Signal Recording System with a High Sampling Rate: Field Tests and Application Forecasts // Seismic Instruments. Vol. 55. № 6. p. 720-726.

Докладчик: Иванов Станислав Дмитриевич, к.т.н., с.н.с., $\underline{\text { f0ma@ifz.ru }}$ 


\title{
ЭНЕРГЕТИЧЕСКАЯ КЛАССИФИКАЦИЯ АКУСТИЧЕСКИХ СОБЫТИЙ ПО КОДЕ СИГНАЛА
}

\author{
Карцева Т.И. ${ }^{1,2}$, Шапиро Н.М. ${ }^{2,4}$, Патонин А.В. ${ }^{3}$, Смирнов В.Б. ${ }^{1,2}$, \\ Пономарёв $A$. B. $^{2}$ \\ 1 Физический факультет МГУ им. М.В. Ломоносова \\ 2 ИФЗ, РАН, лаборатории 107 и 301 \\ 3 ЦПГИ ГО «Борок», ИФЗ РАН, Борок, Ярославская обл \\ 4 ISTERRE, CNRS, Университет Гренобль-Альпьl, Гренобль, Франция
}

Предложена новая методика энергетической классификации акустических событий, регистрируемых в лабораторных экспериментах по разрушению горных пород. Методика основана на анализе данных о коде волн событий акустической эмиссии $[1,2]$. Волны в коде рассматриваются как реверберация акустического поля в испытываемом образце [3]. Новая классификация опробована на двух экспериментах, проведенных на разных породах: гранитах Воронежского массива и песчанике Береа, на управляемом гидравлическом прессе INOVA-1000 Геофизической обсерватории «Борок», ИФЗ РАН. Сравнение новой классификации с применяемой в ГО «Борок» показало, что обе методики дают хорошо согласующиеся результаты в среднем диапазоне энергий событий АЭ. Для сильных событий, начальные части сигналов которых оказываются ограничены параметрами регистрирующей аппаратурой, новая методика показала лучшие результаты. Она позволила получить энергетические оценки таких событий по неискаженной хвостовой части коды.

Методика и результаты данной работы опубликованы в журнале «Сейсмические приборы» [4].

Работа выполнена при финансовой поддержке гранта Министерства образования и науки No 075-15-2021-628 «Геофизические исследования, мониторинг и прогноз развития катастрофических геодинамических процессов на Дальнем Востоке $P \Phi_{»}$

Экспериментальная часть исследований обеспечена оборудованием ЦКП ИФЗ РАН «Петрофизика, геомеханика и палеомагнетизм».

\section{Список литературы:}

1. Раутиан Т.Г. Об определении энергии землетрясений на расстоянии до 3000 км // Экспериментальная сейсмика. М.: Наука, 1964. с. 88-93.

2. Aki K., Chouet B. Origin of coda waves: source, attenuation, and scattering effects //Journal of geophysical research. 1975. T. 80. №. 23. c. 3322-3342.

3. Farin, M., Mangeney, A., De Rosny, J., Toussaint, R., Sainte-Marie, J., \& Shapiro, N. M. Experimental validation of theoretical methods to estimate the energy radiated by elastic waves during an impact //Journal of Sound and Vibration. 2016. T. 362. c.176-202.

4. Кариева Т.И., Шапиро Н.М., Патонин А.В., Смирнов В.Б., Пономарёв А.В. Энергетическая классификация акустических событий по коде сигнала // Сейсмические приборы. 2021. Т. 57, № 3. с.29-40

Докладчик: Карцева Татьяна Игоревна, м.н.c., ti.kartceva@physics.msu.ru 


\section{ПРОВЕДЕНИЕ РАСЧЕТА СЕЙСМИЧЕСКОЙ ИНТЕНСИВНОСТИ НА УЧАСТКАХ РАСПРОСТРАНЕНИЯ СКАЛЬНЫХ ГРУНТОВ Кауркин М. Д. ${ }^{1,2}$}

${ }^{1}$ ИФЗ РАН, Инженерной сейсмологии и интерпретачии сейсмических наблюдений (306)

${ }^{2}$ ИГЭ РАН, инженерной геофизики и сейсмического микрорайонирования

Сейсмическое микрорайонирование (СМР) является отдельным видом работ, выполняемым при проведении инженерных изысканий. Задачей сейсмического микрорайонирования является оценка влияния местных условий (грунтовых, геоморфологических, гидрологических и геофизических) на возможное сейсмическое воздействие. Полученные при СМР характеристики, такие как максимально возможное значение ускорения, период и спектральный состав колебаний поверхности грунта, являются важной информацией для принятия проектных решений.

Однако в настоящий момент существует много несоответствий в методике расчета сейсмической интенсивности. Основным методом сейсмического микрорайонирования является метод сейсмических жесткостей (МСЖ), основы которого разработаны С.В. Медведевым [1,2]. Метод основан на эмпирически установленном факте влияния сейсмической жесткости грунтов на ускорения их колебаний при землетрясениях и на степень повреждения сооружений. В настоящее время в нормативной документации [36] существует несколько вариантов усовершенствованной формулы метода сейсмических жесткостей.

С другой стороны, при проведении работ по сейсмическому микрорайонированию применяется расчетный метод, который заключается в моделировании реакции грунтовой толщи на сейсмическое воздействие. Достаточно часто метод сейсмических жесткостей и расчетный метод не коррелируются в рамках одного участка исследований.

В докладе рассмотрено несоответствие в расчетах сейсмической интенсивности для случая, когда участок исследования сложен скальными грунтами I категории по сейсмическим свойствам.

\section{Список литературы:}

1. Медведев С.В., Шебалин Н.В. С землетрясением можно спорить / М.: Наука, 19672.

2. Медведев C.B. Сейсмическое районирование территории СССР // Сейсмическое районирование СССР. - М.: Наука, 1968. - С.8-24

2. СП 269.1325800.2016 Транспортные сооружения в сейсмических районах. Правила уточнения исходной сейсмичности и сейсмического микрорайонирования. М.:

Стандартинформ, 2017.

3. СП 283.1325800.2016 Объекты строительные повышенной ответственности. Правила сейсмического микрорайонирования. М.: Стандартинформ, 2017.

4. РСН 60-86 Инженерные изыскания для строительства. Сейсмическое микрорайонирование. Нормы производства работ. М.: МосЦТИСИЗ Госстроя РСФСР. $-1987$.

5. РСН 65-87 Инженерные изыскания для строительства. Сейсмическое микрорайонирование. Технические требования к производству работ. М.: МосЦТИСИЗ Госстроя РСФСР. - 1987.

Докладчик: Кауркин Михаил Дмитриевич, к.т.н., в.н.с., Kaurkin_m@mail.ru 


\section{НАБЛЮДЕНИЯ ЭЛЕКТРИЧЕСКОГО СОСТОЯНИЯ ПРИЗЕМНОЙ АТМОСФЕРЫ И СТАТИСТИЧЕСКИЕ ОЦЕНКИ \\ Климанова Е.В., Анисимов С.В., Галиченко С.В., Афиногенов К.В.} Лаборатория геофизического мониторинга ГО «Борок» ИФЗ РАН, Борок

Образующиеся в результате воздействия галактических и солнечных космических лучей, гамма-квантов и энергичных частиц, возникающих при распаде изотопов радона и его дочерних продуктов, лёгкие ионы дрейфуют в электрическом поле и переносятся с ветром. В приземной атмосфере перечисленные процессы влияют на распределение заряда, и следовательно на её электрическое состояние [1 - 3]. Определённое равновесие, наблюдающееся в невозмущённых погодных условиях как стохастические флуктуации около среднего, нарушаются в окрестностях облаков с развитой электрической структурой, в том числе и грозовых.

На основе экспериментального комплекса ГО «Борок» в летне-осенний период 2020 и 2021 годов были получены длительные ряды концентрации лёгких ионов с синхронными измерениями метеопараметров. Данные разбивались на два типа: невозмущённые условия и экстремальные события. Для первой категории измерений были получены аппроксимации функций плотности вероятности усечёнными устойчивыми распределениями [4], рассчитаны автокорреляционные функции для концентрации лёгких ионов и температуры и проведены оценки скейлинга структурных функций. Для второго типа выбирались предгрозовые события, характеризующиеся сильным изменением электрически параметров. Анализировалась взаимосвязь в эволюции полярных проводимостей и атмосферного электрического поля.

Работа выполнена при поддержке Российского научного фонда, грант №16-1710209 (полевые натурные наблюдения) и государственного задания ГО «Борок» ИФЗ РАН, проект 0144-2014-00155 (обсерваторские наблюдения).

\section{Список литературы:}

1. Anisimov S.V., Galichenko S.V., Aphinogenov K.V., Guriev A.V., Kozmina A.S. Prokhorchuk A.A, Klimanova E.V. Electricity of mid-latitude atmospheric boundary layer above land: results of observations and numerical modeling // Turbulence, Atmosphere and Climate Dynamics. Febr. 2019. 231(1):012007.

2. Анисимов С.В., Галиченко С.В., Афиногенов К.В., Мареев Е.А., Шлюгаев Ю.В., Прохорчук А.А., Гурьев А.В., Микрюков П.А. Электрическое состояние приземной атмосферы по результатам аэростатных наблюдений // Доклады Академии наук. 2018. Т. 481. № 2. C. 197 - 202.

3. Anisimov S.V., Galichenko S.V., Aphinogenov K.V., Klimanova E.V., Prokhorchuk A.A., Kozmina A.S., Guriev A.V. Mid-latitude atmospheric boundary layer electricity: A study by using a tethered balloon platform // Atmos. Res. 2020. V. 250, 105355.

4. Menn C., Rachev S.T. Smoothly truncated stable distributions, GARCH-models, and option pricing // Math. Meth. Oper. Res. 2009. V. 69, № 3. P. 411-438.

Докладчик: Климанова Екатерина Вадимовна, м.н.c., klimanova@borok.yar.ru 


\section{РЕЗУЛЬТАТЫ ОБРАБОТКИ ГЕОЛОГИЧЕСКИХ СТРЕСС-ИНДИКАТОРОВ \\ ЮЖНОЙ ЧАСТИ КАНДАЛАКШСКОГО ЗАЛИВА \\ Гордеев Н.А. ${ }^{1}$, Клоков И.А. ${ }^{2}$, Стрельников А.А. ${ }^{2}$}

${ }^{1}$ ИФЗ РАН, Лаборатория фундаментальных и прикладных проблем тектонофизики (204)

${ }^{2}$ ИФЗ РАН, лаборатория палеосейсмологии и палеогеодинамики (304)

Зона Кандалакшского грабена является одним из сейсмически активных участков, который характеризуется слабой современной сейсмичностью. В исследуемом регионе около 12 тыс. лет назад растаял ледник (порядка 2500 м [1]), что привело к этапу разгрузки. За время инструментальных исследований зарегистрировано около 40 землетрясений магнитудой до 5.

Нами в 2021 году собрано порядка 1000 стресс-индикаторов на территории Керетского архипелага и Чупинской губы. Результаты тектонофизического анализа показали, что на территории Керетского архипелага действует геодинамический режим растяжения со сдвигом [2]. Мы связываем это с историей развития этого региона, постоянное растяжение и формирование структурно-тектонических рвов вдоль Кандалакшского грабена [3].

Общее поле напряжения ориентировано северо-восточным сжатием для Кандалакшского грабена, однако в некоторых местах встречается субширотное и северозападное сжатия.

\section{Список литературы:}

1. Величко А. А., Фаустова М. А., Писарева В. В., Карпухина Н. В. История Скандинавского ледникового покрова и окружающих ландшафтов в валдайскую ледниковую эпоху и начале голоцена // Лёд и снег. 2017. Т. 57. № 3. С. 391-416. - DOI 10.15356/2076-6734-2017-3-391-416.

2. Гордеев H. A., Бондарь И.В. Тектонофизический анализ южного берега Кандалакшского залива // Труды Ферсмановской научной сессии ГИ КНЦ РАН. 2021. № 18. C. 119-123. DOI 10.31241/FNS.2021.18.021.

3. Гордеев Н.А., Клоков И.А., Стрельников А.А. Результаты обработки геологических стресс-индикаторов для доголоценовых землетрясений Кандалакшского района // Труды Ферсмановской научной сессии ГИ КНЦ РАН. 2021. № 18. С. 124-129. DOI 10.31241/FNS.2021.18.022.

Докладчик: Клоков Илья Анатольевич, инженер, ilia.klokov@ifz.ru 


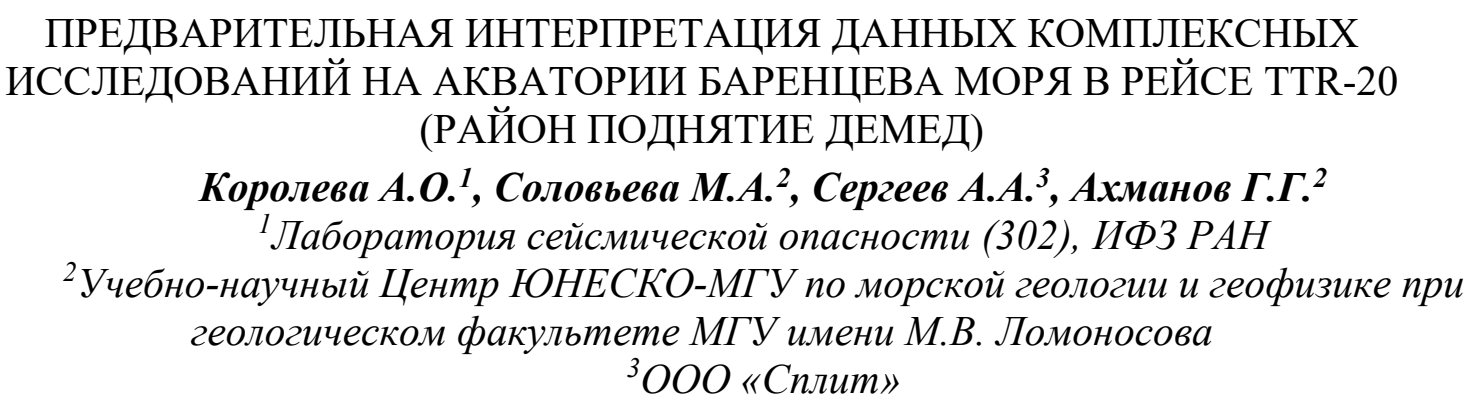

Введение. Интерес к шельфам Арктических морей постоянно растет. Это связано с открывающимися большими перспективами освоения минеральных ресурсов Арктики. C 14 сентября по 14 октября 2021 года состоялась Международная экспедиция TTR-20 (Training-through-Research) на НИС «Академик Николай Страхов». Район работ располагался между архипелагами Новая Земля и Земля Франца Иосифа в северной части Баренцева моря, являющейся одной из самых малоизученных областей западной Арктики, и включал девять полигонов детальных исследований, названных участниками экспедиции именами древнегреческих муз.

Цели. В рамках экспедиции в районе работ был выполнен комплекс геологогеофизических и микробиологических исследований с целью изучения строения верхних горизонтов осадочного чехла, генезиса придонных отложений, картирования разнообразных форм суб-гляциального рельефа и изучения разнообразия микроорганизмов, обитающих в донных осадках. В данной работе представлена предварительная интерпретация данных, полученных на полигоне №6 (Эрато), в районе поднятия Демед.

Методика. Проведены сейсмоакустические работы методом 2D МОГТ (тип источника - электроискровой («спаркер»), тип приемника - сейсмическая коса), акустическое профилирование (профилограф EdgeTech 3300), а также многолучевое эхолотирование с использованием двух многолучевых эхолотов - SeaBat 8111 (для мелководной части) и SeaBat 7150 (для глубоководной части). По результатам экспрессобработки геофизических данных и построения батиметрических карт рельефа морского дна определялись точки геологического опробования, проводимого при помощи гравитационного пробоотборника ударного типа. Образцы полученного керна изучались в лабораториях на борту. Также на них были выполнены ультразвуковые исследования.

Pезультаты. По морфологии рельефа полигон можно разделить на две части. В мелководной части полигона отмечаются многочисленные борозды ледникового выпахивания, могут быть выделены моренные гряды Де Гира, холмы Роген морен, а также структуры мега-масштабной ледниковой линейности. Глубоководная часть полигона представлена субширотно вытянутой каньонообразной впадиной, расширяющейся и выполаживающейся на восток. Предварительно установлено, что данная впадина имеет тектоническую природу. На это указывает ряд признаков, отмеченных на сейсмоакустических разрезах.

Благодарности. Экспедиция TTR-20 организована геологическим факультетом МГУ имени М.В. Ломоносова и ИО РАН при поддержке Министерства науки и высшего образования РФ и в партнёрстве с инновационной компанией «Сплит» и ООО «ЦМИ МГУ». Экспедиция вошла в список мероприятий Года науки и технологий.

Докладчик: Королева Александра Олеговна, н.c., kao@ifz.ru 
МНОГОКАНАЛЬНОЕ DАQ УСТРОЙСТВО ДЛИТЕЛЬНОЙ РЕГИСТРАЦИИ

АКУСТИЧЕСКИХ ДАННЫХ

Краюшкин Д.В. ${ }^{1,2}$, Кох В.В. ${ }^{1,2}$, Казначеев П.А. ${ }^{1}$

${ }^{1}$ ИФЗ РАН, Лаборатория физики землетрясений и неустойчивости горных пород (301)

${ }^{2}$ Национальный исследовательский университет «МЭИ»

В настоящее время при проведении лабораторных испытаний существует проблема захвата множества исследуемых сигналов в режиме реального времени и их последующей обработки.

Для решения данной проблемы необходимо разработать систему [1], способную отслеживать большое количество сигналов в процессе выполнения эксперимента, с возможностью их последующей обработки и сохранения в памяти.

Данные системы должны обладать следующими преимуществами, по сравнению с традиционно используемыми стандартными лабораторными измерительными приборами (осциллографами и т.п.):

- большое количество измерительных каналов;

- высокая частота дискретизации;

- регистрация данных на всем промежутке лабораторных испытаний;

- обработка полученных данных.

Для снятия акустических параметров был разработан регистратор сигналов на базе LabView и DAQ устройстве [2], осуществляющий захват данных 8-и каналов с частотой дискретизации 1 МГц на канал. DAQ устройство обладает возможностью передачи данных в режиме реального времени на ПК. С помощью встроенного программного обеспечения LabView разработано приложение, с удобным интерфейсом для визуального анализа, позволяющее совершать обработку и преобразование данных с их последующим сохранением на диск.

В результате данной работы, с помощью многоканального ресторатора, были проведены лабораторные исследования по снятию сигнала акустического зондирования экспериментального образца.

\section{Список литературы:}

1. Баран Е.Д., LabVIEW FPGA. Реконфигурируемые измерительные и управляющие системы / / ДМК Пресс, 2009 г.

2. National instruments, DAQ-устройства M серии, руководство пользователя устройств / / 2008 г.

Докладчик: Кох Виктор Витальевич, vitya.kohh@mail.ru 


\section{ИЗУЧЕНИЕ НОВЕЙШЕЙ ГЕОДИНАМИКИ И УТОЧНЕНИЕ ГЛУБИННОГО ТЕКТОНИЧЕСКОГО СТРОЕНИЯ РАЙОНА ОЗЕРА МАНЫЧ-ГУДИЛО Кочевой Н.Г. ${ }^{1,2}$, Андреева Н.В. ${ }^{1}$ \\ ${ }^{1}$ Институт физики Земли им. О.Ю. Шмидта РАН \\ ${ }^{2}$ Московский Государственный Университет им. М.В. Ломоносова}

В районе оз. Маныч-Гудило проведен ряд исследований, включающий в себя структурно-геоморфологический анализ в комплексе с методом микросейсмического зондирования (ММ3) [1]. Целью данных работ являлось выявление новейших дислокаций и уточнение положения очага Сальского землетрясения 2001г.

Район исследований является слабосейсмичным и с точки зрения тектоники приурочен к эпипалеозойской платформенной области, которая в данном регионе представлена кряжем Карпинского, Ставпропольским сводом и Скифской плитой, включающей зону Манычских прогибов [2].

По результатам структурно-геоморфологического анализа, включавшего в себя дешифрирование данных дистанционного зондирования и полевые геологические исследования, с использованием программного пакета ArcGIS, были построены структурно-геоморфологические карты. При помощи метода MM3 в районе исследования пройдены глубинные профили, при интерпретации которых выделялись дизъюнктивные нарушения. Корреляция геофизических профилей со структурногеоморфологическими картами позволила увязать проявления поверхностных нарушений с глубинными скоростными неоднородностями.

При сопоставлении геоморфологических данных с данными ММЗ установлено, что дислокации, выявленные структурно-геоморфологическим методом, прослеживаются на глубину от 5 до 15 км. Анализ всех полученных данных позволил предположить, что очаг Сальского землетрясения (2001г., M=4.7) приурочен к одной из ветвей Манычского разлома и подтверждает результаты инструментальных определений Геофизической службы РАН [3].

Таким образом, совместное использование геолого-структурных и геофизических методов (ММЗ) является перспективным инструментом при исследовании платформенных территорий.

\section{Список литературы:}

1. Горбатиков А.В., Степанова М.Ю., Кораблев Г.Е. Закономерности формирования микросейсмического поля под влиянием локальных геологических неоднородностей и зондирование среды с помощью микросейсм // Физика Земли. 2008. №7. С. 66-84

2. Государственная геологическая карта РФ. L-(37), (38), 2000

3. Габсатарова И.П., Чепкунас Л.С., Бабкова Е.А., Татевосян Р.Э., Плетнев К.Г. Сальское землетрясение 22 мая 2001 года с MS=4.7, I0=6-7 (Северный Кавказ) // Землетрясения Северной Евразии 2001г. Обнинск: ГС РАН, 2007. С. 301-316

Докладчик: Кошевой Николай Георгиевич, лаборант, koshevoi98@inbox.ru 


\section{СРАВНИТЕЛЬНЫЙ АНАЛИЗ МОДЕЛЕЙ ФОРМИРОВАНИЯ ЛОКАЛЬНЫХ НАПРЯЖЕНИЙ В ЗОНАХ РАЗДВИГОВЫХ РАЗЛОМОВ НЕФТЕГАЗОНОСНЫХ РЕГИОНОВ}

Кузьмин Д.К.

Лаборатория современной и прикладной геодинамики (201), ИФЗ РАН

Известно, что и напряжения, и деформации являются отражением двух основных форм (силовой и кинематической) единого процесса - движения [1]. Поэтому для полного описания современной геодинамики разломных зон необходимо построение количественных моделей, описывающих напряженно-деформированное состояние с обеих точек зрения. [8,9,10]. Наиболее опасными деформационными последствиями разработки месторождений УВ является деформации разломных зон $[2,3,4,5,6,7]$.

Рассматриваются результаты сравнительного анализа формирования локальных напряжений, полученные двумя аналитическими моделями - объемной (параметрической) и дислокационной (с нулевой толщиной). В результате установлено, что уровень локальных напряжений в рамках параметрической модели в 3-5 раз меньше значений напряжений, полученных в дислокационной модели, что объясняется отсутствием толщины разлома в модели раздвиговой дислокации.

\section{Сиисок литературы:}

1. Кузьмин Ю. О. Проблемные вопросы изучения деформационных процессов в современной геодинамике // Горный информационно - аналитический бюллетень (научно-технический журнал). 2008. № 3. С. 98-107.

2. Кузьмин Ю.О. Современная аномальная геодинамика недр, индуцированная разработкой месторождений нефти и газа // Фундаментальный базис новых технологий нефтяной и газовой промышленности. Вып.2. М.: ГЕОС. 2002а. С. 418 - 427.

3. Кузьмин Ю.О. Современная аномальная геодинамика недр, индуцированная малыми природно-техногенными воздействиями // Горный информационно - аналитический бюллетень (научно-технический журнал). №9. 2002б. С. 48-55.

4. Кузьлин Ю. О. Современная геодинамика раздвиговых разломов // Физика Земли. 2018. №6. C. $87-105$.

5. Кузьмин Ю.О. Индуцированные деформации разломныз зон // Физика Земли. 2019. №5. С. 6 -75 .

6. Кузьмин Ю.О. Современная геодинамика разломов и эколого-промышленная безопасность объектов нефтегазового комплекса // Геология, геофизика и разработка нефтяных и газовых месторождений, 2007. №1. С. 33-41.

7. Кузьмин Ю.О., Никонов А.И. Геодинамическая природа аварийности скважин и трубопроводных систем / В кн.: Перспективы развития экологического страхования в газовой промышленности. М., Газпром. 1998. С. 315-328.

8. Кузьмин Д.К. Сопоставление моделей деформационной активности раздвиговых разломов с результатами геодинамического мониторинга объектов нефтегазового комплекса // Проблемы недропользования. 2019. №4. С. $18-27$.

9. Кузьмин Ю.О. и др. Анализ результатов деформационных наблюдений системой инклинометров на месторождении им. В. Филановского // Геофизические процессы и биосфера. 2019. T. 18, № 4. С. 86-94.

10. Кузьмин Д.К. Оценка напряженного состояния недр на разрабатываемых месторождениях нефти и газа //Маркшейдерский вестник. 2020. №5. С.37 - 43.

Докладчик: Кузьмин Дмитрий Кузьмич, м.н.c, dimak1292@mail.ru 
ПРИМЕНЕНИЕ КАППАМЕТРИИ В ВОПРОСАХ КОРРЕЛЯЦИИ, СТРАТИГРАФИИ И ГЕОХРОНОЛОГИИ ЛЁССОВО-ПОЧВЕННЫХ СЕРИЙ ЮЖНОГО ТАДЖИКИСТАНА

Кулакова Е.П., Мещерякова О.А. ${ }^{1}$, Курбанов Р.Н.,

${ }^{1}$ ИФЗ РАН, Лаборатория главного геомагнитного поля и петромагнетизма (105)

${ }^{2}$ Институт географии Российской академии наук

${ }^{3}$ Московский государственный университет имени М.В. Ломоносова

Лёссово-почвенные серии (ЛПС) широко распространены на территории Евразии, обрамляя с юга весь континент от Китая через Центральную Азию и Поволжье до Западной Европы. Данные осадочные породы являются уникальным архивом климатической информации четвертичного периода, отражая в своем литологическом составе чередование ледниковий и межледниковий (лёсс и почвы, соответственно). Однако, для корректных реконструкций климата необходимо понимать стратиграфическую полноту разрезов и их возраст.

На настоящий момент существует проблема датирования ЛПС абсолютными геохронологическими методами, чей возраст превышает 300 тыс. лет. Метод оптически стимулированной люминесценции (ОСЛ) успешно заявил себя в детальном датировании ЛПС до этой отметки возраста. Но для более древних частей ЛПС может быть применим только палеомагнитный метод, дающий лишь точечные даты магнитных событий. Поэтому при стратиграфической неполноте разреза остается затруднительным точное определение возраста каждого его участка.

Измерение магнитной восприимчивости (каппаметрия) ЛПС зарекомендовало себя как информативный и доступный метод для решения вопросов геохронологии, стратиграфии и региональной корреляции разрезов. Это основано на прямой корреляции изменения магнитной восприимчивости с кривой морских изотопных стадий (МИС), что справедливо для ЛПС Китая, Центральной Азии [1] и Европы. Так, для этих регионов пики значений магнитной восприимчивости соответствуют почвенным горизонтам и соотносятся с пиками теплых нечетных МИС. Соотнесение данных каппаметрии с МИС дает возрастную оценку на любой части разреза, позволяет выделять перерывы в осадконакоплении, предполагать эрозионные границы и производить региональную и межрегиональную корреляцию различных разрезов.

В докладе будут представлены первые данные каппаметрии для ЛПС Южного Таджикистана и показаны возможности и перспективы ее применения для решения стратиграфических и геохронологических задач региона.

Работа выполнена при финансовой поддержке РФФИ в рамках научного проекта №20-55-56046.

\section{Сиисок литературы:}

1. Shackleton N.J., An Z., Dodonov A.E., Gavin J., Kukla G.J., Ranov V.A., Zhou L.P. Accumulation rate of loess in Tajikistan and China: Relationship with global ice volume cycles // Quatern. Proceedings. 1995. Vol. 4. P. 1-6

Докладчик: Кулакова Екатерина Петровна, н.c., ek.kula@yandex.ru 


\section{ОПРЕДЕЛЕНИЕ НАПРАВЛЕНИЙ ЕСТЕСТВЕННОЙ ОСТАТОЧНОЙ НАМАГНИЧЕННОСТИ САМОЕДСКОЙ СВИТЫ В ДОЛИНЕ Р. ВЕРХНЯЯ ТАЛОВАЯ (НОРИЛЬСКИЙ РАЙОН) \\ Латанова Е.А. ${ }^{1,2}$, Латышев А.В. ${ }^{2,3}$ \\ ${ }^{1}$ ИФЗ РАН, Лаборатория главного геомагнитного поля и петромагнетизма (105) \\ ${ }^{2}$ Геологический факультет МГУ им. М.В. Ломоносова \\ ${ }^{3}$ ИФЗ РАН, Лаборатория археомагнетизма и эволюичи магнитного поля Земли (106)}

В рамках данной работы основной задачей являлось получение данных о средних направлениях естественной остаточной намагниченности базальтов самоедской свиты норильской лавовой толщи, которые необходимы для получения временных ограничений на продолжительность формирования пермо-триасовой вулканогенной толщи Норильского района и разработки опорной кривой вековых вариаций для последующей возрастной корреляции рудоносных интрузий с туфо-лавовой толщей.

Во время полевых работ производился отбор ориентированных образцов из лавовых потоков самоедской свиты (средняя и верхняя пачки) в долине р. Верхняя Таловая. Всего из самоедской свиты было отобрано 233 образца (11 сайтов). На этапе лабораторных работ была произведена чистка переменным полем и термочистка с использованием магнитометров SQUID SRM, JR-6 (AGICO) и термопечи MMTD80.

По результатам расчетов, выполненных в пакете программ Энкина [1], можно сделать следующие выводы:

1. Все образцы из средней пачки самоедской свиты намагничены в прямой полярности.

2. В верхней пачке образцы из нижних потоков также характеризуются прямой полярностью, а три верхних потока - обратной.

В ходе работы были впервые получены представительные палеомагнитные данные по разрезу самоедской свиты с использованием современной методически-аппаратурной базы палеомагнитных исследований. Направления остаточной намагниченности пород самоедской свиты в изучаемом районе также рассматривались в других работах $[2,3]$. В целом полученные результаты им не противоречат и подтверждают последние данные [3] о наличии потоков, намагниченных в обратной полярности.

\section{Список литературы:}

1. Enkin R.J. A computer program package for analysis and presentation of paleomagnetic data. Pacific Geoscience Centre, Geol. Surv. Can., 1994. P. 16.

2. Gurevitch, E.L.; Heunemann, C.; Rad'ko, V.; Westphal, M.; Bachtadse, V.; Pozzi, J.P.; Feinberg, $H$. Palaeomagnetism and magnetostratigraphy of the Permian-Triassic northwest central Siberian Trap Basalts // Tectonophysics. 2004. V.379. P. 211-226.

3. Latyshev A.V., Fetisova A.M., Veselovskiy R.V. Linking Siberian Traps LIP Emplacement and End-Permian Mass Extinction: Evidence from Magnetic Stratigraphy of the MaymechaKotuy Volcanic Section // Geosciences. 2020. V. 10. № 8. P. 295.

Докладчик: Латанова Елена Александровна, студент, Lenaaa1212@,gmail.com 


\section{ПРОБЛЕМЫ СТРАТИГРАФИИ И ВОЗРАСТА ФОРМИРОВАНИЯ ВУЛКАНИТОВ СЕВЕРНОЙ ЧАСТИ ОХОТСКО-ЧУКОТСКОГО ВУЛКАНИЧЕСКОГО ПОЯСА \\ Лебедев И.Е., Тихомиров П.Л.}

Лаборатория Археомагнетизма и эволюиии магнитного поля Земли (106), ИФЗ РАН

До последних десятилетий в стратиграфии Охотско-Чукотского вулканического пояса (ОЧВП) господствовали традиционные методы корреляций, которые в первую очередь основываются на палеоботанических данных. Однако на сегодняшний день растет число работ с использованием прецизионных методов изотопного датирования (U-Pb и Ar-Ar), надежность и достоверность которых ощутимо выше, чем у традиционно используемых. Новые данные позволили ревизировать возрастные рамки формирования выделенных ранее стратонов, тем не менее на данный момент таких данных явно недостаточно [1].

В рамках данной работы получены новые U-Pb и Ar-Ar датировки для окрестностей двух эпитермальных золото-серебряных месторождений на Чукотке: Купол и Валунистое. Окрестности данных месторождений относятся к разным сегментам (секторам) ОЧВП по Белому В.Ф. Месторождение Купол находится границе Анадырского и Центрально-Чукотского секторов, а Валунистое в Восточно-Чукотском.

В большинстве случаев полученные возраста заметно отличаются от принятых последним стратиграфическим совещанием, и если для окрестностей месторождения Купол полученные датировки просто омололаживают исследованные стратоны, то в районе месторождения Валунистое некоторые из полученных изотопных дат не вписываются даже в принятые общие временные рамки формирования ОЧВП (106-74 млн лет) [2]. До нашего исследования уже предлагалась модель [1] более позднего формирования Восточно-Чукотского сектора относительно остальной части ОЧВП. Наши новые данные подтверждают молодой возраст верхних частей разреза ВосточноЧукотского сектора, однако возможно, что опробованные нами стратоны уже не относятся к ОЧВП, а генетически связаны с более молодым, сравнительно слабо изученным Анадырско-Бристольским поясом (кампан-палеоценовым), который распространен южнее изученного района.

Работа выполнена при финансовой поддержке гранта РНФ № 19-47-04110.

\section{Список литературы:}

1. Сахно В.Г., Полин В.Ф., Акинин В.В., Аленичева А.А., Тихомиров П.Л., Молл-Столкап Э.Дж. Разновременность формирования Амгуэмо-Канчаланского и Энмываамскго вулканических полей ОЧВП по данным изотопного датирования // Докл. РАН. Науки о Земле. 2010. Т. 434. № 3. C. $365-371$.

2. Тихомиров П.Л. Меловой окраинно-континентальный магматизм Северо-Востока Азии и вопросы генезиса крупнейших фанерозойских провинций кремнекислого вулканизма. - М.: ГЕОС, 2020. 376 с.

Докладчик: Лебедев Иван Евгеньевич, н.c., lebedev232@ya.ru 
ИССЛЕДОВАНИЕ НАЧАЛЬНЫХ ЭТАПОВ ДЕФОРМИРОВАНИЯ ГОРНЫХ ПОРОД С ПОМОЩЬЮ ЦИКЛИЧЕСКИХ МНОГОСТАДИЙНЫХ ИСПЫТАНИЙ

Леонова А.М., Фокин И.В., Гизатуллин Д.М., Егоров Н.А.

Центр петрофизических и геомеханических исследований, ИФЗ РАН, Москва

В работе представлены результаты экспериментальных исследований механических свойств горных пород в обстановке трехосного сжатия.

Специальные циклические многостадийные испытания для изучения деформационных свойств пород, расчета динамических и статических механических свойств, таких как модуль Юнга, скорости продольных и поперечных волн, были проведены на образцах, изготовленных из керна, взятого с одного из месторождений Западной Сибири.

Испытания проводились на сервогидравлической установке высокого давления [1], для образцов из разных глубинных интервалов и пластов.

Динамические модули были рассчитаны по скоростям продольных и поперечных волн, которые возбуждались пьезопреобразователями на верхнем торце образца и регистрировались приемником на нижнем. Статические модули были определены по зависимостям напряжений от деформаций.

Специальная методика проведения испытания заключалась в циклическом многократном ступенчатом нагружении образца с выдержкой на каждой ступени до стабилизации деформаций. При этом максимальное напряжение оставалось значительно ниже предела упругости породы. В результате были определены нелинейные зависимости напряжений от деформаций на начальном участке нагружения.

При построении зависимостей статических модулей Юнга от динамических, было обнаружено, что они достаточно точно аппроксимируются прямой, несмотря на разные характеристики пород. Однако, имеются точки, не следующие общему тренду. При сравнении параметров и характеристик, принадлежащих таким образцам, с образцами, не выбивающимися, было обнаружено, что накопленная пластическая деформация между вторым и третьим, а также третьим и четвертым циклами нагружения все еще присутствовала, тогда как у остальных образцов она была несущественна либо отсутствовала совсем. Необратимость деформаций, накопленных при повторных малых нагружениях, может быть связана с повышенной пористостью образцов, приведшей к значительным изменениям внутренней структуры в процессе выбуривания и перемещении из пластовых условий в атмосферные.

Отдельное внимание было уделено нелинейности кривой деформирования при малых напряжениях. Было обнаружено, что секущий статический модуль Юнга линейно зависит от разницы деформаций двух точек на кривой деформирования, по которым он рассчитывался. Это свидетельствует о том, что начальный участок кривой деформирования изученных пород практически точно может быть аппроксимирован полиномом второй степени. Интересно отметить, что этот результат был обнаружен как на начальном, так и на повторных циклах нагружения для всех образцов.

Полученные результаты могут быть использованы при дальнейших исследованиях изучаемого месторождения Западной Сибири.

\section{Сиисок литературы:}

1. Тихочкий С.А., Фокин И.В., Баюк И.О., Белобородов Д.Е., Березина И.А., Гафурова Д.Р., Дубиня Н.В., Краснова М.А., Корост Д.В., Макарова А.А., Патонин А.В., Пономарев A.В., Хамидуллин Р.А., Цельмович В.А. Комплексные лабораторные исследования керна в ЦПГИ ИФЗ РАН // Наука и технологические разработки, 2017. Т.96. №2. С.17-32.

Докладчик: Леонова Анастасия Михайловна, инженер ЦПГИ, lam@ifz.ru 


\section{ХАРАКТЕРНЫЕ ГЕОЛОГО-ГЕОФИЗИЧЕСКИЕ ПРИЗНАКИ РУДОНОСНЫХ УЗЛОВ КАВКАЗА И АЛТАЙ-САЯНСКОГО РЕГИОНА \\ Ливинский А.И.,}

${ }^{1}$ Институт теории прогноза землетрясений и математической геофизики РАН ${ }^{2}$ Институт физики Земли им. О.Ю. Шмидта РАН

В работе рассматриваются горно-складчатые системы Кавказа и Алтай-Саяна, в которых преобладает полиметаллическое оруденение и известно достаточно большое количество месторождений металлов разных масштабов. Целью работы является определение характерных геолого-геофизических признаков мест локализации месторождений металлов. В современных металлогенических исследованиях связь рудных месторождений с узлами пересечения линеаментов установлена во многих регионах с различной тектонической обстановкой [3,4]. Представленная работа основывается на установленной ранее связи крупномасштабного оруденения с узлами пересечения линеаментов [3] и развивает подход, заложенный в работах [1,2], в которых использовались методы распознавания образов для определения рудоносных узлов пересечений линеаментов в горных поясах Средиземноморья.

Работа выполнялась в два этапа. На первом этапе методом морфоструктурного районирования были выделены узлы пересечения линеаментов и рассмотрена пространственная связь рудных месторождений с узлами. В каждом рассматриваемом регионе установлено, что крупномасштабные месторождения локализованы в окрестностях узлов пересечений линеаментов. Все узлы были охарактеризованы единым набором геолого-геофизических параметров

На втором этапе с помощью алгоритма распознавания образов КОРА-3 были определены характерные геолого-геофизические и геоморфологические признаки, на основе которых в каждом регионе все узлы были разделены на 2 класса:

- Класс P, рудоносные узлы

- Класс НР, нерудоносные узлы

В процессе обучения алгоритм определил характерные признаки для каждого класса. На этапе классификации все узлы каждого региона были разделены на рудоносные в зависимости от преобладающего количества признаков каждого класса. В результате в каждом регионе были определены потенциально рудоносные узлы, характерные признаки которых представлены интервалами численных значений, использованных геолого-геофизических и геоморфологических параметров.

\section{Список литературы:}

1. Горшков А.И., Соловьев А.А. Определение характеристик рудоносных узлов методами распознавания образов // Крупные и суперкрупные месторождения: закономерности размещения и условия образования. М.: ИГЕМ РАН, 2004. С.381-390.

2. Горшков А.И., Соловьев А.А. (2006). Распознавание облика рудных месторождений в поясе Тетис. В кн.: Крупные и суперкрупные месторождения рудных полезных ископаемых. В трех томах. Том.1. Глобальные закономерности размещения (ред. Д.В.Рундквист). М.: ИГЕМ РАН. С.361-374.

3. Лопатин Д.В. Линеаментная тектоника и месторождения-гиганты Северной Евразии// Иссл. Земли из космоса. 2002. №2. С. 77-91. Геодинамические аспекты распределения крупных и суперкрупных месторождений в глобальных металлогенических поясах и провинциях. 2006.

4. Ткачев А.В., Рундквист Д.В., Черкасов С.В., Вишневская Н.В., Гатинский Ю.Г., Чесалова Е.И., Арбузова Е.Е., Лебедев И.О., Кутузова Н.И. База данных крупных и суперкрупных месторождений мира. 2006.

5. Mineral atlas of the world. Geological survey of Norway. 2000. 400 p.

Докладчик: Ливинский Артем Игоревич, м.н.c, artem@mitp.ru 


\section{СОПОСТАВЛЕНИЕ РЕЗУЛЬТАТОВ ИЗМЕРЕНИЙ МЕТОДАМИ \\ СПУТНИКОВОЙ И НАЗЕМНОЙ ГЕОДЕЗИИ НА ОДНОМ ИЗ НЕФТЕГАЗОВЫХ МЕСТОРОЖДЕНИЙ КАЗАХСТАНА \\ Ломоносов М.Д.}

Лаборатория современной и прикладной геодинамики (201), ИФЗ РАН

Основу инструментальных наблюдений на геодинамических полигонах нефтегазовых месторождений составляют повторные нивелирные и ГНСС наблюдения. Нивелирные измерения направлены, в первую очередь на контроль динамики формирования обширного оседания земной поверхности территории всего месторождения и деформационной активности разломных зон. Повторные ГНСС измерения используются для уточнения пространственной картины распределения векторов вертикальных и горизонтальных смещений земной поверхности $[1,2,3,4,5]$.

На изучаемом месторождении было выполнено 14 циклов повторных нивелирных и ГНСС измерений в период времени с 2012 г. по 2018 г. По данным нивелирования установлено слабое поднятие в центральной части месторождения, обусловленной закачкой жидкости в пласт для интенсификации разработки. Кроме этого, выявлено систематическое локальное оседание земной поверхности в разломной зоне характерное для большинства нефтегазовых месторождений $[6,7]$.

Сопоставление вертикальных и горизонтальных смещений, полученных по данным спутниковой геодезии, входят в противоречие с наземными данными и особенностями процесса разработки, что неоднократно отмечалось на других геодинамических полигонах [8]. Сформулированы рекомендации по изменению пространственной детальности наблюдательной сети и методам измерений.

Работа выполнена в рамках государственного задания ИФЗ РАН.

\section{Сиисок литературы:}

1. Кузьмин Ю.О. Современная аномальная геодинамика недр, индуцированная разработкой месторождений нефти и газа // Фундаментальный базис новых технологий нефтяной и газовой промышленности. Вып.2. М.: ГЕОС. 2002а. С. 418 - 427.

2. Кузьмин Ю.О. Современная геодинамика раздвиговых разломов // Физика Земли. 2018. №6. C. 87-105.

3. Кузьмин Ю.О. Индуцированные деформации разломных зон // Физика Земли. 2019. №5. C. 61-75.

4. Кузьмин Ю.О., Никонов А.И. Геодинамическая природа аварийности скважин и трубопроводных систем / В кн.: Перспективы развития экологического страхования в газовой промышленности. М., Газпром. 1998. С. 315-328.

5. Кузьмин Ю.О. Современная геодинамика разломов и эколого-промышленная безопасность объектов нефтегазового комплекса // Геология, геофизика и разработка нефтяных и газовых месторождений, 2007. №1. С. 33-41.

6. Кузьмин Ю.О. Проблемные вопросы изучения деформационных процессов в современной геодинамике // Горный информационно - аналитический бюллетень (научно-технический журнал). 2008. № 3. С. 98-107.

7. Кузьмин Ю.О. Современная геодинамика: от движений земной коры до мониторинга ответственных объектов // Физика Земли. 2019. № 1. С. 78 - 103.

8. Кузьлин Ю.О. Актуальные вопросы использования геодезических измерений при геодинамическом мониторинге объектов нефтегазового комплекса // Вестник СГУГИТ. 2020. Том 25. №1. С. 43 - 54.

Докладчик: Ломоносов Михаил Дмитриевич, аспирант, mclomonosov@gmail.com 


\section{ТРЕХМЕРНАЯ МОДЕЛЬ ЮГА ФЕННОСКАНДИИ ПО ДАННЫМ ИНВЕРСИИ ПРИЕМНЫХ ФУНКЦИЙ}

Малыгин И.В., Алешин И.М.

Институт физики Земли им. О.Ю.Шмидта РАН

При изучении свойств коры и верхней мантии широкое применение получили методы, основанные на анализе приемных функций. Приемные функции позволяют определить свойства коры и верхней мантии непосредственно под сейсмостанцией. Совместный анализ данных, зарегистрированных на группе станций, дает возможность построить трехмерную сейсмическую модель региона.

Разработан метод построения цифровой модели региона по совокупности одномерных зависимостей упругих параметров от глубины. Метод применен к данным инверсии волновых форм приемных функций, полученных ранее [1], построена цифровая модель южной части Фенноскандии.

В качестве исходных данных использованы одномерные модели: зависимость скорости поперечных волн от глубины для 23 широкополосных станций пассивного сейсмического эксперимента SVEKALAPKO. Модели получены совместным обращением волновых форм приемной функции, дисперсионной кривой рэлеевских волн и времени пробега обменных волн от верхней границы переходной зоны мантии [1]. Для параметризации использовались однородные упругие слои переменной толщины. В ситуации, когда механические свойства среды под станциями слабо меняются по латерали, для построения трехмерной цифровой модели возможно метод, изложенный в [2]. Его идея состоит в масштабном преобразовании горизонтальных координат, которое нивелирует различие между вертикальным и горизонтальным распределением данных, и при удачном выборе масштабного множителя пространственное распределение данных становится практически изотропным.

Цифровой образ строится в виде набора горизонтальных срезов. В качестве метода интерполяции выбран метод $k$ ближайших соседей. В качестве внешних параметров (гиперпараметров) задачи использовались число ближайших соседей и масштабный множитель (аналогично [2]), а также шаг дискретизации по глубине для построения трехмерного образа. Определение всех гиперпараметров задачи способами на основе машинного обучения решает задачу построения цифровой модели региона: модельное значение Vs может быть автоматически вычислено методом $k$ ближайших соседей.

Полученные результаты являются продолжением предыдущих исследований [2]. Представленный метод является универсальным. Он не зависит от способа получения одномерных моделей, при этом форма сечений не сводится к плоскости, ориентированной горизонтально или вертикально, и может быть произвольной.

\section{Список литературы:}

1. Kozlovskaya E., Kosarev G.L., Aleshin I.M., Riznichenko O.Yu., Sanina I.A. Structure and composition of the crust and upper mantle of the Archean-Proterozoic boundary in the Fennoscandian shield obtained by joint inversion of receiver function and surface wave phase velocity of recording of the SVEKALAPKO array // Geophysical Journal International. 2008. V. 175, №1. P. 135-152.

2. Алёшин И.М., Ваганова Н.В., Косарев Г.Л., Малыгин И.В. Свойства коры Фенноскандии по результатам knn-анализа инверсии приёмных функций// Геофизические исследования. - 2019. - Т. 20, № 4. - С. 25-39.

Докладчик: Малыгин Иван Вячеславович, инженер, malygin.iv@gmail.com 


\section{СВЯЗЬ НОВЕЙШЕГО СТРУКТРУНОГО ПЛАНА ЗАПАДНО-СИБИРСКОЙ \\ ПЛИТЫ С ДРЕВНИМИ ДИСЛОКАЦИЯМИ И МЕСТОРОЖДЕНИЯМИ УГЛЕВОДОРОДОВ \\ Мануилова Е.А. ${ }^{1}$, Панина Л.В. ${ }^{2}$ \\ ${ }^{1}$ ИФЗ РАН, Лаборатория фундаментальных и прикладных проблем тектонофизики (204) \\ ${ }^{2}$ МГУ имени М.В. Ломоносова геологический факультет, кафедра динамической геологии}

Проведение структурно-геоморфологического анализа рельефа [1] на территории Западно-Сибирской плиты, позволил установить ее новейший структурный план. В результате выделены неотектонические области, региональные и локальные новейшие структуры, а также слабые зоны и слабые зоны со сдвиговой составляющей. Интерпретация геоморфологических профилей, по комплексам признаков [1], позволила выявить разрывные нарушения без установления их кинематики. Дальнейшее сопоставление слабых зон (в том числе и со сдвиговой составляющей), выявленных в плане с разрывными нарушениями, установленными на геоморфологических профилях, позволило перевести часть слабых зон в ранг новейших разрывных нарушений. Дополнительно для уточнения границ региональных и местами локальных структур проведены построение карт по методу В.П. Философова [2] и автоматизированное дешифрирование [3]. В результате сопоставления новейших структур с дислокациями фундамента и осадочного чехла проведено ранжирование новейших пликативных и разрывных структур по степени унаследованности. Таким образом, на территории исследования установлены новейшие унаследованные, обращенные и новообразованные пликативные структуры. Отметим, что простирания древних структур отличаются от современных, и наследование происходит лишь фрагментарно. При сопоставлении новейших разрывных нарушений с древними разломами прослеживаются унаследованные и новообразованные разрывные нарушения. Их преобладающие простирания - северо-западное и северо-восточное, местами субмеридиональное, прослеживаются от структур фундамента. Сопоставление расположения месторождений УВ с новейшими структурами позволило установить признаки их локализации: приуроченность в основном к областям новейших региональных унаследованных впадин, разломам со сдвиговой составляющей северо-западного и северовосточного простирания, участкам с высокой (66-100\%) и низкой $(0-33 \%)$ плотностью линеаментов.

Исследования проведень в рамках Госзадания ИФЗ РАН.

\section{Список литературы:}

1. Костенко Н.П. Геоморфология. М.: Изд-во Моск. ун-та, 1999. 379 с.

2. Философов В.П. Краткое руководство по морфометрическому методу поисков тектонических структур, Саратов: Изд-во СГУ, 1960. 69 с.

3. Златопольский A.A. Пакет прикладных программ выделения и анализа линейных элементов аэрокосмических изображений // Автоматизированный линеаментный анализ при структурно-геологических и металлогенических исследованиях. М.: Недра, 1988. С. $14-28$.

Докладчик: Мануилова Екатерина Алексеевна, н.c., e.manuilova@,ifz.ru 
ПРИМЕНЕНИЕ МЕТОДА МАSW ДЛЯ ВЫДЕЛЕНИЯ ГЕОЛОГИЧЕСКИХ ОПАСНОСТЕЙ В ПЕЧОРСКОМ МОРЕ

Марятов А.К. ${ }^{1}$, Титов Н.О. ${ }^{1}$, Токарев М.Ю. ${ }^{1}$, Горбачёв С.В. ${ }^{2}$, Гурвич Л.А. ${ }^{2}$, Вакуленко C.A. ${ }^{3}$

${ }^{1}$ Московский государственный университет им. М.В. Ломоносова

${ }^{2} \mathrm{OOO} \mathrm{«РН-Шельф-Арктика»}$

${ }^{3}$ ООО «Деко-геофизика СК»

Метод многоканального анализа поверхностных волн MASW (Multichannel analysis of surface waves) в наземной инженерной сейсморазведке является быстрым и простым методом определения скоростей поперечных волн в горных породах верхней части разреза (до 100м). Благодаря созданию донного сейсмического оборудование применение метода MASW стало возможно и в морских мелководных условиях при глубине воды 0-30м и при глубине до 100м при использовании придонного буксируемого источника.

В данной работе метод MASW был применён к записи донных станций в Печорском море, полученных методикой 3D-сейсморазведки с использованием источника типа пневмопушка. На исходном лицензионном участке при помощи атрибутного анализа были выделены газонасыщенные зоны, зоны распространения палеоврезов и зоны распространения многолетнемёрзлых пород (ММП). В данных зонах автором была выполнена обработка сейсмических данных методом MASW, получены разрезы скоростей поперечных волн, построены объёмные модели поперечных скоростей и проведено сравнение результатов обработки методом MASW и атрибутного анализа, позволившие сделать вывод о том, что аномально пониженные значения скоростей поперечных волн совпадают с зонами газонасыщенных осадков, имеют достаточную корреляцию с зонами распространения палеоврезов и практически не коррелируют с зонами распространения ММП. Однако, корреляция с ММП отсутствует, скорее всего, из-за относительно большой глубины залегания ММП, так как поверхностные волны распространяются на глубину не более 150-200м.

\section{Список литературы:}

1. Park C.B., Miller R.D., Xia J., Ivanov J., Sonnichsen G.V., HunterJ.A., et al. 2005. Underwater MASW to evaluate stiffness of waterbottom sediments. The Leading Edge 24, 724-728.

2. Вакуленко С.А., Понимаскин А.И., Токарев М.Ю., Горбачев С.В., Гурвич Л.А. Применение технологии многогоканального анализа поверхностных волн (MASW) для решения задач оценки свойств придонных отложений по результатам 2D/3D сейсмической съемки с донным оборудованием на шельфе Печорского моря, Конференция «Морские технологии 2021» 2021г.

Докладчик: Марятов Антон Константинович, аспирант, maryatov-a@,mail.ru 


\section{ФАЗОВЫЕ ПРЕВРАЩЕНИЯ ГЕОМАТЕРИАЛА ПРИ СЕЙСМИЧЕСКИХ СКОРОСТЯХ ПОДВИЖКИ \\ Матвеев М.А., Смульская А.И., Морозов Ю.А.}

ИФЗ РАН, Лаборатория тектоники и геодинамики (103)

В рамках изучения особенностей процессов плавления и последующей кристаллизации расплава в ходе сейсмического смещения, нами были изучены образцы псевдотахилитов (ПСТ), возникшие при фрикционном плавлении по метатерригенным породам исходно аркозового состава и входящие в палеопротерозойский зонально-метаморфизованный ладожский комплекс юговостока Балтийского щита (Северное Приладожье). Для изучения структур и состава ПСТ был проведен их анализ на микрозонде и на сканирующем электронном микроскопе.

Матрица ПСТ визуально напоминает вулканическое стекло, содержащее класты исходной породы и отдельных составляющих ее минералов. Минералы протолита и кластов в ПСТ одинаковы, но соотношения минералов в кластах изменились по сравнению с их пропорциями в протолите, то есть плавление минералов было избирательным, ослабевая в ряду Mus $\rightarrow \mathrm{Bi} \rightarrow \mathrm{Pl} \rightarrow \mathrm{Q}$. Подобный механизм плавления описан Спреем для фрикционных расплавов: плавление происходит за несколько секунд, из-за чего отсутствует взаимодействие между минералами; они плавятся независимо друг от друга, в порядке возрастания индивидуальных температур плавления [1].

Фрикционный нагрев неравномерен в плоскости сдвига и зависит от степени измельчения, топографии поверхности и других факторов [1]. Можно весьма приблизительно оценить температуру расплава. Мусковит плавится полностью, на $100 \%$; биотит - на $85 \%$; плагиоклаз - на 75\%, что указывает на повсеместное преодоление нижнего предела в $650^{\circ} \mathrm{C}\left(\mathrm{T}_{n л} \mathrm{Mus}\right)$, частое - в $850^{\circ} \mathrm{C}\left(\mathrm{T}_{n л} \mathrm{Bi}\right)$ и локальное до $1200^{\circ} \mathrm{C}\left(\mathrm{T}_{n л} \mathrm{P}_{\text {№25 }}\right)$. Кварцевые класты подплавляются на $12 \%$, что указывает на точечное достижение $1700^{\circ} \mathrm{C}\left(\mathrm{T}_{n л} \mathrm{Q}\right)$. Таким образом, интервал расплавных температур колеблется от $850^{\circ}$ до $1200^{\circ} \mathrm{C}$ с локальными вспышками до $1700^{\circ} \mathrm{C}$.

С прекращением фрикционного воздействия расплав остывает с образованием микролитов и стекла. Было установлено наличие в плагиоклаз-кварцевом матриксе ПСТ чешуек биотита и иллита, при полном отсутствии микролитов плагиоклаза. Установлен следующий ряд кристаллизации: расплав $\rightarrow$ Bi $\rightarrow$ Mus + остаточное Pl-Qстекло.

Применение программы Melts подтверждает этот порядок кристаллизации, соответствующий реакциям боуэновской серии во время фракционирования [2]. Таким образом, при весьма краткосрочном формировании ПСТ механизм неравновесного фрикционного плавления сменяется классическим механизмом остывания, кристаллизации или остеклования пластовых магматических тел.

Работа выполнена в рамках государственного задания ИФЗ РАН и при финансовой поддержке РФФИ в рамках научного проекта № 19-05-00256.

\section{Список литературы:}

1. Spray J.G. A physical basis for the frictional melting of some rock-forming minerals // Tectonophysics. 1992. V. 204. P. 205-221.

2. Bowen N.L. The Evolution of Igneous Rocks. Princeton University Press. 1928. 229 p

Докладчик: Матвеев Максим Алексеевич, н.c., mma@ifz.ru 
ИССЛЕДОВАНИЕ ПОСТЛЕДНИКОВЫХ ДВИЖЕНИЙ ФЕННОСКАНДИИ ПО ЗАРУБЕЖНЫМ И РОССИЙСКИМ ДАННЫМ ГНСС

Мельник Г.Э. ${ }^{1,2}$, Стеблов Г.М. ${ }^{1}$

${ }^{1}$ ИФЗ РАН, Лаборатория спутниковых методов изучения геофизических процессов (203)

${ }^{2}$ ФГБУ «Центр геодезии, картографии и ИПД»

Наиболее изученным геодинамическим процессом, определяющим современную геодинамику Феноскандии, согласно общепринятым представлениям, является постледниковое поднятие (гляциоизостазия). В рамках этих представлений причины наблюдаемых поднятий состоят в оледенении, охватившем около 10-11 тысяч лет назад северо-западную часть Евразии, включающую географические территории Норвегии, Швеции, Дании, Финляндии, а также северо-западные регионы России (Кольский полуостров, Карелия и север Ленинградской области).

По данным повторных спутниковых определений координат с помощью измерений на станциях ГНСС, расположенных на территории Фенноскандии, за период с середины 90-х годов прошлого века и по настоящее время, проведён анализ геодинамики региона. Использован расширенный по территории набор данных, включающий станции Международной службы ГНСC (IGS) с постоянной регистрацией сигналов, пункты фундаментальной астрономо-геодезической сети РФ, а также наблюдения Лаборатории спутниковых методов изучения геофизических процессов ИФЗ РАН. Это позволило распространить область моделирования постледниковой геодинамики Фенноскандии на ее восточную часть без использования экстраполяции. Как и во многих предыдущих исследованиях подтверждено поле вертикальных скоростей с максимумом интенсивности поднятия на уровне 10 мм/год, располагающимся в северной части Ботнического залива. Кроме того, для восточных областей Фенноскандии выделена полоса площадных деформаций сжатия земной поверхности, маркирующая зону перехода от куполообразного поднятия к Восточно-Европейской платформе, что согласуется с возвратным астеносферным течением после снятия ледовой нагрузки в голоцене.

Докладчик: Мельник Геннадий Эдуардович, аспирант, melnik@ifz.ru 


\section{НАГРУЗОЧНЫЕ ЧИСЛА ЛЯВА ДЛЯ РАЗЛИЧНЫХ МОДЕЛЕЙ НЕОДНОРОДНОЙ УПРУГОСТИ ВЕНЕРЫ \\ Менщикова Т.И.}

ИФЗ РАН, Лаборатория происхождения, внутреннего строения и динамики Земли и планет (102)

Рассчитаны нагрузочные числа Лява для различных моделей неоднородной упругости Венеры, используя статический подход $[1,2]$ для нагрузки на поверхности (рельеф планеты) и для заглубленных аномальных волн плотности. Планета моделируется как упругое самогравитирующее тело, с зависящими от радиуса плотностью, модулем сжатия и модулем сдвига. Для расчета нагрузочных коэффициентов решается система уравнений, в которую входят: уравнение упругого равновесия; уравнение Пуассона, связывающего аномальный гравитационный потенциал с распределением плотности. Вычисления проводятся для каждой гармоники до степени и порядка $\mathrm{n}=70$, исходя из точности определения гравитационного поля на данный момент. Используются данные топографии (модель SHTJV360u [3]) и данные гравитационного поля (модель SHGJ180u, [4]). В работе рассматриваются несколько вариантов моделей неоднородной упругости Венеры. Как первое приближение принимается чисто упругая модель - Модель А. Во втором случае (Модель В) предполагается наличие упругой литосферы. Под литосферой вводится ослабленный слой, который частично потерял свои упругие свойства. Ослабление в этом слое моделируется пониженным в десять раз значением модуля сдвига, слой считается простирающимся до ядра. Толщина упругого литосферного слоя варьируется от 100 до 500 км. В третьей модели - модели С - в ослабленном слое по корой задается градиентное изменение модуля сдвига: пониженное в десять раз значение модуля сдвига непосредственно под корой постепенно увеличивается до значения в упругой модели на границе с ядром. На основе этих моделей проводится интерпретация аномального внешнего гравитационного поля.

Работа выполнена за счет бюджетного финансирования ИФЗ РАН.

\section{Список литературы:}

1. Марченков К.И., Любимов В.М., Жарков В.Н. Расчет нагрузочных коэффициентов для заглубленных аномалий плотности // Докл. АН СССР. 1984. Т.15 (2). С.583-586.

2. Жарков В.Н., Марченков К.И., Любимов В.М. О длинноволновых касательных напряжениях в литосфере и мантии Венеры // Астрономический Вестник. 1986. Т.20 (3). C. 202-211.

3. Rappaport N. J., Konopliv A. S., Kucinskas A. B. An improved 360 degree and order model of Venus topography // Icarus. 1999. V.139. P. 19-31.

4. Konopliv A.S., Banerdt W.B., Sjogren W.L. Venus gravity:180th degree and order model Icarus. 1999. V. 139. P. 3-18.

Докладчик: Менщикова Тамара Ивановна, аспирант, н.c., ms.tamm@mail.ru 


\section{ПЕРВЫЕ ПЕТРОМАГНИТНЫЕ РЕЗУЛЬТАТЫ ДЛЯ ЛЁССОВО-ПОЧВЕННОГО} РАЗРЕЗА ХОНАКО-ІІ (СРЕДНЯЯ АЗИЯ)

Мещерякова О.А. ${ }^{1}$, Кулакова Е.П. ${ }^{1}$, Курбанов Р.Н. ${ }^{2,3}$

${ }^{1}$ ИФЗ РАН, Лаборатория главного геомагнитного поля и петромагнетизма (105)

${ }^{2}$ Институт географии Российской академии наук

${ }^{3}$ Московский государственный университет имени М.В. Ломоносова

Введение. Лессово-почвенные серии (ЛПС) являются уникальным палеогеографическим архивом, содержащим в себе информацию об этапах оледенений и межледниковий. Лессовые отложения залегают покровами на территории Китая, Сибири, Средней Азии, Европы, Северной Америки. При этом ЛПС Средней Азии в настоящее время являются наименее изученными, несмотря на то, что там уже описаны многочисленные лессово-почвенные разрезы [1]. На сегодняшний день остается ряд нерешенных вопросов стратиграфии и геохронологии, отмечается нехватка данных, полученных современными методами. Уникальной особенностью ЛПС Средней Азии является наличие археологических артефактов: в почвенных комплексах 1 и 2 обнаружено множество орудий Мустьерской культуры, а нижние педокомплексы охарактеризованы наличием орудий галечной индустрии $[1,2]$. Объект исследования разрез Хонако-ІІ расположен в 7 км северо-восточнее поселка Ховалинг (Ховалингский район) (38.4 $4^{\circ}$ сш., $70.1^{\circ}$ в.д.). Этот разрез входит в состав лессово-почвенного обнажения возрастом приблизительно 1.5 млн. лет [1], общей мощностью более 180 метров. В экспедиции 2019 года нами были отобраны образцы для палео- и петромагнитного анализа в верхней части разреза (первые 40.8 метров), включающей в себя педокомплексы 1 и 2.

Методика. Петромагнитный метод позволяет определить гранулометрию, состав, концентрацию магнитных минералов, являясь незаменимым тсточником информации для построения палеоклиматических реконструкций. Нами будут представлены первые петромагнитные результаты, полученные для пилотной коллекции из 25 образцов (по 5 образцов из каждого горизонта лессов и палеопочв).

Результаты. Первые результаты позволили выявить закономерности распределения магнитной восприимчивости по разрезу, при этом магнетит является основным магнитным минералом-носителем с небольшим присутствием маггемита и гематита (незначительно, менее 5\%). Были обнаружены значительные изменения в концентрации и размере магнитных минералов в горизонтах различных эпох (потепления и похолодания), при этом различий в составе магнитных минералов не выявлено. Далее нами планируется более подробно изучить зависимость изменения петромагнитных параметров от литологического горизонта (лёссы и палеопочвы). В результате этого мы получим детальные изменения природной среды Средней Азии для среднего и верхнего плейстоцена, что будет важно не только для палеогеографических реконструкций, но также и для изучения палеолита в лессово-почвенных сериях.

\section{Список литературы:}

1. Додонов A. E. Четвертичный период Средней Азии (Стратиграфия, корреляция, палеогеография). М.: ГЕОС, 2002. 250 c.

2. Ранов В.А., Шефер Й. Лессовый палеолит // Археология, этнография и антропология Евразии. 2000. № 2 (21). C. 20-32.

Докладчик: Мешерякова Ольга Андреевна, вед. инж., oliya@,ifz.ru 


\section{ПОДХОД К ПОСТРОЕНИЮ РЕГИОНАЛЬНЫХ МОДЕЛЕЙ \\ СЕЙСМИЧЕСКОГО ЭФФЕКТА НА ПРИМЕРЕ БАЙКАЛЬСКОГО РЕГИОНА \\ Миронов В.A. ${ }^{1,2}$, Перетокин С.A. ${ }^{2,3}$ \\ ${ }^{1}$ Институт вычислительного моделирования СО РАН, Красноярск \\ ${ }^{2}$ Красноярский филиал Федерального исследовательского иентра информачионных и вычислительных технологий, Красноярск \\ ${ }^{3}$ ИФЗ РАН, Лаборатория сейсмической опасности (302)}

Оценка сейсмической опасности на основе вероятностного анализа сейсмической опасности (BАCO) - неотъемлемая часть комплекса инженерно-геологических изысканий в сейсмически активных регионах. Важной задачей при выполнении ВАСО является построение моделей затухания сейсмического эффекта с расстоянием, также именуемых как уравнения прогнозирования движения грунта (УПДГ). Данные модели строятся на основе региональных баз данных, полученных по результатам сейсмологических наблюдений. Современные модели затухания прогнозируют физические характеристики движения грунта (амплитуды колебаний, спектры реакции грунта и др.), которые зависят от расстояния до очага землетрясений, типа подвижки, магнитуды, характеристик грунта на площадке и др. При этом, от качества, полноты и достоверности исходных данных зависит корректность полученной модели и, следовательно, обоснованность итоговых оценок сейсмической опасности.

Настоящая работа посвящена развитию алгоритмов и разработке программных модулей обработки записей землетрясений. В основе предложенных алгоритмов лежит методология, использованная для реализации научного проекта NGA-West2 [1], в результате которого разработана обширная база данных записей землетрясений в сейсмоактивных регионах [2], а также реализованы современные глобальные и региональные УПДГ.

Исходными данными в работе являются 252 записи от 53 землетрясений, зарегистрированных региональной сетью сейсмических станций. Применяемые алгоритмы были адаптированы к особенностям сейсмического мониторинга Байкальского региона и реализованы в среде MATLAB.

Разработанное программное обеспечение предназначено для автоматизированной обработки большого количества исходных записей землетрясений. Процесс обработки состоит из последовательности шагов, в результате которых вычисляются значения PGA (пиковое ускорение грунта), PGV (пиковая скорость грунта) и спектры реакции ускорения грунта. Предлагаемый подход позволит сформировать базу данных сильных движений, отвечающую единому набору критериев, как основу для построения региональных моделей затухания.

Работа выполнена по теме гос. задания №0144-2019-0010 с использованием данных, полученных на уникальной научной установке «Сейсмоинфразвуковой комплекс мониторинга арктической криолитозоны и комплекс непрерывного сейсмического мониторинга Российской Федерации, сопредельных территорий и мира».

\section{Список литературы:}

1. Bozorgnia Y., et al. NGA-West2 Research Project // Earthquake Spectra. 2014. V. 30. No. 3. P. 973-987.

2. Ancheta T.D., et al. NGA-West2 Database // Earthquake Spectra. 2014. V. 30. No. 3. P. 9891005 .

Докладчик: Миронов Василий Александрович, аспирант, vasya-kun@mail.ru 


\section{СКАЧОК НАПРЯЖЕНИЙ В СЛОИСТОЙ ТРАНСВЕРСАЛЬНО-ИЗОТРОПНОЙ СРЕДЕ}

Молокоедов А. $\boldsymbol{C}$.

Московский физико-технический институт

Работа посвящена проблеме оценки напряжений в слоистых средах в применении к нетрадиционным коллекторам углеводородов. Задача оценки напряжений в массивах горных пород является актуальной для решения множества задач геомеханики месторождений. Существуют различные подходы к оценке напряжений в массивах горных пород, среди которых можно выделить подход, основанный на рассмотрении массива как слоистой упругой среды, подверженной действию внутренних напряжений. Как было показано в работе [1], распределение напряжений, действующих в слоистой упругой среде, каждый слой которой изотропен, может быть определено аналитически, если известны упругие модули, характеризующие каждый слой, и два независимых напряжения, действующие в одном из слоев. Основой для такой реконструкции является требование непрерывности вектора смещения при переходе через интерфейс между слоями.

Данная работа посвящена обобщению результатов, полученных в работе [1], на случай, при котором один или несколько слоев упругой среды является трансверсально изотропным. Продемонстрировано, что знание компонент тензора податливости в этом случае позволяет аналитически определить скачки компонент тензора напряжений при переходе через интерфейс между слоями. Отмечено, что случай слоистой среды с изотропными слоями является частным случаем рассмотренной задачи. Исследовано влияние степени выраженности анизотропии на величину скачка напряжений.

Полученные в работе результаты могут быть использованы для реконструкции напряжений в слоистых средах с трансверсально изотропными упругими слоями по точечным измерениям напряжений. В частности, полученные результаты позволяют определить скачки напряжений в часто встречающемся при разработке и освоении нетрадиционных коллекторов углеводородов: при переходе из изотропных пород, находящихся над насыщенными коллекторами к трансверсально изотропным породам, слагающим сами коллектора. Рассчитанные таким образом напряжения могут быть использованы для решения задач устойчивости ствола скважин для снижения рисков при бурении.

\section{Список литературы:}

1. Дубиня Н.В., Галыбин А.Н. О распределении напряжений в слоистом массиве горных пород // Физика Земли. 2018. №6. С. 106-116.

Докладчик: Молокоедов Александр Сергеевич, студент, molokoedov.as@phystech.edu 


\section{ИССЛЕДОВАНИЯ ВЛИЯНИЕ МАЛЫХ ТАНГЕНЦИАЛЬНЫХ ГРАВИТАЦИОННЫХ СИЛ НА ГЛОБАЛЬНОЕ ПОЛЕ НАПРЯЖЕНИЙ Мягков Д.С., Ребецкий Ю.Л.}

ИФЗ РАН, Лаборатория фундаментальных и прикладных проблем тектонофизики (204)

Поиск всей совокупности сил, ответственных за движение литосферных плит, является важной задачей современной глобальной геодинамики. В условиях наличия огромного количества детальных геофизических и геодезических данных для всей планеты в целом, возникает возможность по новому, с количественных позиций взглянуть на такие задачи, как формирование дополнительных тангенциальных массовых сил, связанных с отклонением формы физической поверхности Земли (ФПЗ) от геоида. Считается, что данным отклонением в геодинамике можно пренебречь [1], хотя рассматривалась задача о влиянии ускорения и замедления вращения Земли при действии центробежных сил на генерацию тангенциальных массовых сил в литосфере [2]. В данной работе показано, что отклонение геоида от ФПЗ способно вызвать вполне заметные по уровню напряжения (касательные напряжения уровня $0.3 \mathrm{MПа),} \mathrm{которые}$ могут рассматриваться как один из заметных геодинамических факторов, влияющих на движение литосферных плит.

В работе были использованы детальные карты рельефа (от $0.5^{\circ}$ до $5^{\prime}$ ) и геоид из модели EGM 96. В качестве основного исследуемого параметра рассматривался угол отвесной линии (УОЛ). На основе полученных значений УОЛ далее рассчитывались величины генерируемых в литосфере напряжений. Для расчёта распределения связанных с отклонением формы ФПЗ от геоида УОЛ использовался аппарат сферических функций, позволяющий получить нужный масштаб усреднения. Получены амплитуды тангенциальных массовых сил для каждой точки поверхности Земли, показаны силы, действующие на отдельные плиты.

Показано, что тангенциальные массовые силы могут создавать достаточно существенные по амплитуде нормальные горизонтальные напряжения уровня 10 МПа и выше. В работе [3] обсуждается тот момент, что при интегрировании по глубине для литосферы в целом максимальные касательные напряжения могут превышать значения в первые десятые доли МПа и, поэтому, рассматриваемые тангенциальные массовые силы могут являться самостоятельным источником движения плит. Для отдельных плит, таких как Амурская или Охотская, этот фактор особенно существенен.

\section{Список литературы:}

1. Turcotte D., Shubert G. Geodynamics. Cambridge University Press; 3rd Edition. 2014. 636 p.

2. Стовас М.В. Избранные труды. М.: Недра, 1975. 155 с. [Stovas M.V. Selected works. M.: Nedra, 1975. 155 p. (in Russian)].

3. Ребецкий Ю.Л., Мягков Д.С. Генезис тангенциальных массовых сил в литосферных плитах и их роль в геодинамике // Вестник КРАУНЦ. 2020. № 3. С. 88-97.

Докладчик: Мягков Дмитрий Сергеевич, нс, dsm@ifz.ru 


\section{ИССЛЕДОВАНИЕ НЕОДНОЗНАЧНОСТИ РЕШЕНИЯ ОБРАТНЫХ ЗАДАЧ ПЕТРОУПРУГОГО МОДЕЛИРОВАНИЯ С ПОМОЩЬЮ НЕЙРОННОЙ СЕТИ Насретдинова Д.И.}

ИФЗ РАН, Лаборатория фундаментальных проблем нефтегазовой геофизики и геофизического мониторинга

Интересно, может ли компьютер с огромным количеством ресурсов памяти имитировать работу мозга? Подобный вопрос привел человечество к созданию теории нейронных сетей. В настоящее время нейронные сети активно участвуют в нашей жизни, начиная с автоматического распознавания автомобильных номеров и заканчивая FACE ID в вашем телефоне. Искусственный интеллект не обошел стороной и геологоразведку.

При определении форм порового пространства геофизики всегда сталкиваются с неопределённостью. Необходимо определить область возможных решений и понять, как эти решения отличаются друг от друга. Есть риски подобрать неверные параметры, не глядя на строение породы. В таком случае прогноз будет абсолютно неверным.

Интересно, можно ли научить нейронную сеть решать данную проблему? Сможет ли она определить форму порового пространства, зная только объемное содержание минералов, их плотность и интервальное время пробега продольной волны? С этим вопросом предстоит разобраться.

Объектом исследования данной работы является пласт Б1 (Осинский горизонт) в скважинах лицензионных участков Восточной Сибири.

В работе описывается алгоритм создания нейронной сети и ее применимость в исследовании неоднозначности решения обратных задач петроупругого моделирования.

Докладчик: Насретдинова Диана Ильдаровна, аспирант, obsidianchiknas@gmail.com 


\section{ИССЛЕДОВАНИЕ РАСПРОСТРАНЕНИЯ ТРЕЩИН В СЛОЖНЫХ ПОРОДАХ- КОЛЛЕКТОРАХ НА МИКРОУРОВНЕ \\ Начев В. A. ${ }^{1,2}$, Турунтаев C.Б. ${ }^{1}$}

${ }^{1}$ Институт динамики геосфер имени академика М.А. Садовского

Российской академии наук (ИДГ РАН)

${ }^{2}$ Московский физико-технический институт (национальный исследовательский университет)

Нетрадиционные нефтегазовые породы-коллекторы обладают крайне низкой проницаемостью, что приводит к образованию малых дренажных зон вокруг добывающих скважин. Для увеличения зоны дренажа необходимо проводить операции по интенсификации добычи углеводородов в прискважинной зоне, в том числе за счет операций гидравлического разрыва пласта (ГРП). Эта работа направлена на изучение распространения трещин во время операций ГРП, чтобы определить условия, которые приводят к наиболее обширной сети вторичных трещин наряду с первичными трещинами в масштабе пор. Авторы исследуют возникновение и распространение трехмерных трещин, учитывая минеральный состав и сложную текстуру упругопластичных пород, таких как плотные породы и богатые органикой аргиллиты.

Для подготовки репрезентативной цифровой минерально-механической модели исследуемого объема породы мы провели серию лабораторных экспериментов. Для микроструктурного описания породы использовали методы компьютерной томографии (КТ), сканирующей электронной микроскопии (СЭМ) с количественным картированием минералов по поверхности (QEMSCAN). Геомеханическое описание породы включает набор методов, таких как многостадийные испытания на прочность при сжатии, испытания на прямое растяжение (DTS), бразильские испытания на непрямое растяжение (BTS), микро- и наноиндентирование. На основании проведенных испытаний были подготовлены микромасштабные цифровые модели образцов пород, которые описывают структуру, гранулированный состав и пространственное распределение механических свойств. Затем была построена расчетная сетка на основе подготовленной минеральной модели, и с помощью расширенного метода конечных элементов было выполнено моделирование распространения трещин на микроуровне при различных условиях нагружения.

В результате было изучено возникновение и распространение трехмерных трещин, учитывая гранулированный состав и сложную структуру упругопластических образцов горных пород. Численное моделирование позволило рассчитать геометрии и сети трещин для различных условий нагружения.

Докладчик: Начев Виктор Андреевич, м.н.c.,_nachev@phystech.edu 


\section{НЕЙРОСЕТЕВОЙ ПРОГНОЗ ТЕПЛОПРОВОДНОСТИ ПО ДАННЫМ ЭЛЕКТРОМАГНИТНЫХ ЗОНДИРОВАНИЙ В ГЕОТЕРМАЛЬНОЙ ОБЛАСТИ СУЛЬЦ-У-ФОРЕ (ФРАНЦИЯ)}

Ненюкова А.И. ${ }^{1,2}$, Спичак В.В. ${ }^{2}$

${ }^{1}$ МГРИ-РГГРУ имени Серго Орджоникидзе

${ }^{2}$ ЦГЭМИИФЗ РАН

Теплофизические свойства пород, включая удельную теплопроводность, критически важны для исследования термальной эволюции бассейнов, условий образования геологических обстановок, а также разведки геотермальных ресурсов и более точной оценки их потенциала. Их обычно грубо оценивают непосредственно по результатам измерений на образцах пород из пробуренных скважин или по каротажным данным. Между тем, для исследования региональных тепловых процессов необходимо перейти от их прогноза в отдельных скважинах к прогнозу во всем рассматриваемом разрезе. Целью проведенных в работе исследований является нейросетевой прогноз теплопроводности пород по данным наземных магнитотеллурических зондирований вдоль профиля в геотермальной зоне Сульц-су-Форе (Франция). Для этого применяется технология электромагнитного геотермометра [1], нашедшая широкое применение для оценки доминирующих механизмов переноса тепла и локализации его источников в ряде регионов мира [2]. В работе выполнена нейросетевая оценка точности прогнозов коэффициента теплопроводности в пространстве между скважинами по электромагнитным данным, а также лабораторным измерениям на кернах [3]. Перекрестное тестирование искусственных нейросетей показало, что средняя относительная ошибка прогноза коэффициента теплопроводности в пространстве между скважинами может составлять примерно $10 \%$. На основе проведенных исследований впервые построен разрез теплопроводности геотермальной зоны до глубины 5км. Полученные результаты показывают принципиальную возможность построения моделей теплопроводности геотермальных областей по результатам их электромагнитного зондирования и лабораторным измерениям удельной теплопроводности на образцах из имеющихся скважин. Разработанный подход имеет большое практическое значение для определения запасов геотермального тепла, углеводородов, оценки их фазового состояния, решения гидрогеологичеких и других задач.

Работа выполнена при финансовой поддержке РНФ в рамках научного проекта № 20-17-00155.

\section{Список литературы:}

1. Спичак B.B., Захарова О.К. Электромагнитный геотермометр. М.: Научный мир, 2013. $170 \mathrm{c}$.

2. Спичак B.B. Электромагнитная томография земных недр. М.: Научный мир, 2019. 374 c.

3. Heap M.J., Kushnir A.R.L., Gilg H.A., Violay M.E.S., Harlé P., Baud P. Petrophysical properties of the Muschelkalk from the Soultz sous Forêts geothermal site (France), an important lithostratigraphic unit for geothermal exploitation in the Upper Rhine Graben // Geothermal Energy. 2019. P. 7-27.

Докладчик: Ненюкова Алёна Игоревна, nenyukovaai@mail.ru 


\section{АНАЛИЗ ПРОСТРАНСТВЕННО-ВРЕМЕННЫХ ВАРИАЦИЙ МАГНИТУДЫ ПРЕДСТАВИТЕЛЬНОЙ РЕГИСТРАЦИИ ЗЕМЛЕТРЯСЕНИЙ НА КАМЧАТКЕ Павленко В.А., Завьялов А.Д. ИФЗ РАН}

Магнитуда представительной регистрации $M_{c}$ - это минимальная магнитуда, для которой землетрясения в заданном пространственно-временном объёме регистрируются достоверно и без пропусков. Значение $M_{c}$ соответствует началу линейной части графика повторяемости землетрясений, поэтому надёжная оценка $M_{c}$ критически важна для получения корректных оценок параметров Гутенберга-Рихтера. Некорректная оценка величины $M_{c}$ приводит к получению неадекватных значений этих параметров и ошибочной интерпретации данных. Значение $M_{c}$ изменяется в пространстве и во времени, эти вариации необходимо учитывать при работе с каталогами землетрясений для оценки параметров сейсмического режима. Таким образом, анализ пространственновременных вариаций $M_{c}$ становится неотъемлемым элементом решения таких важных задач сейсмологии, как анализ сейсмической опасности и прогноз землетрясений.

В работе проанализированы шесть современных методов оценки $M_{c}$ : два непараметрических $[1,2]$ и четыре параметрических $[1,3,4]$ метода. Для сравнения методов использованы выборки из реальных инструментальных каталогов землетрясений, а также синтетические каталоги, сгенерированные на основе трёх моделей распределения магнитуды, встречающихся при анализе реальных инструментальных каталогов: модель неоднородной выборки, модель однородной выборки, модель выборки, из которой удалены слабые землетрясения [5]. По синтетическим каталогам с помощью метода бутстрап проанализированы зависимости двух первых моментов распределений оценок $M_{c}$ от формы распределения магнитуды и объёма выборки. Предложена процедура оценки $M_{c}$, основанная на анализе формы локального выборочного распределения магнитуды.

Построены карты пространственных распределений $M_{c}$ на Камчатке для последовательных временных интервалов, отражающие устойчивое развитие сейсмической сети и позволяющие получать надёжные оценки параметров сейсмического режима и их временных вариаций.

\section{Список литературы:}

6. Woessner J. and S. Wiemer. Assessing the quality of earthquake catalogues: estimating the magnitude of completeness and its uncertainty. // Bull. Seismol. Soc. Am. 2005. 95. 2. pp. 684 698. doi: $10.1785 / 0120040007$.

7. Amorèse D. Applying a change-point detection method on frequency-magnitude distributions. // Bull. Seismol. Soc. Am. 2007. 97. 5. pp. 1742-1749. doi: 10.1785/0120060181. 8. Cao A. M. and S. S. Gao. Temporal variation of seismic b-values beneath northeastern Japan island arc. // Geophys. Res. Lett. 2002. 29. 9. pp. 48-1-48-3. doi: 10.1029/2001GL013775.

9. Писаренко В. Ф. Дискретные свойства геофизической среды. О законе повторяемости землетрясений. / М.: Наука. 1989. с. 47-60.

10. García-Hernández R., L. D’Auria, J. Barrancos, and G. D. Padilla. On the functional expression of frequency-magnitude distributions: a comprehensive statistical examination. // Bull. Seismol. Soc. Am. 2019. 109. 1. pp. 482-486. doi: 10.1785/0120180197.

Докладчик: Павленко Василий Александрович, к.ф-м.н., н.с., pavlenko.vasily@gmail.com 
РЕЗУЛЬТАТЫ ПАЛЕОМАГНИТНОГО ИССЛЕДОВАНИЯ ЛАМПРОФИРОВ ТОМТОРСКОГО ЩЕЛОЧНОГО МАССИВА (СЕВЕР СИБИРСКОЙ ПЛАТФОРМЫ) Пасенко А.М. ${ }^{1}$, Малышев С.В. ${ }^{2}$, Ситкина Д.Р. ${ }^{3}$

${ }^{1}$ ИФЗ РАН, лаборатория Главного геомагнитного поля и петромагнетизма (105)

${ }^{2}$ Санкт-Петербургский государственный университет, г. Санкт-Петербург

${ }^{3}$ Институт геологии и геохронологии докембрия РАН, г. Санкт-Петербург

В настоящее время количество надежных палеомагнитных полюсов для неопротерозоя Сибирской платформы крайне невелико. В то же время, их достаточное количество является необходимым условием для разработки и тестирования различных геодинамических и палеогеографических реконструкций, что особенно важно в контексте разработки моделей сборки и распада неопротерозойского суперконтинента Родиния, а также тестировании гипотезы Snowball Earth.

На территории Сибирской платформы породы неопротерозойского возраста, подходящие для палеомагнитных исследований, характеризуются крайне невысоким распространением и невысокой степенью обнаженности. При этом исследования осадочных пород зачастую сталкиваются с трудно разрешимыми проблемами определения их возраста. В подобных условиях становится критически важным получение палеомагнитных полюсов по надежно датированным магматическим породам.

В данной работе мы предлагаем новый полюс, полученный по датированным лампрофирам первой фазы внедрения Томторского щелочного массива Уджинского поднятия (возраст определен Ar-Ar методом по флогопиту, 706.1 18.8 млн лет) [1, 2]. Для получения обсуждаемого палеомагнитного полюса авторами была отобрана коллекция, состоящая из 27 образцов четырех маломощных даек и 41 образца вмещающих пород мезопротерозойской унгуохтахской свиты для проведения теста контакта.

Предлагаемый полюс является всего лишь вторым надежно датированным палеомагнитным определением для Сибирской платформы для интервала 950-600 млн лет, что лишний раз указывает на его значимость. Еще одним немаловажным пунктом является совпадение наших данных с палеомагнитным определением по породам медвежевской свиты Лонгдорского поднятия Байкало-Патомской складчатой области, возраст которых оценивается в интервале 720-710 млн лет. Учитывая, что опробованные объекты располагаются в разных удаленных регионах Сибирской платформы, можно говорить о надежности новых палеомагнитных данных.

Предлагаемый авторами полюс, полученный по щелочным породам Томторского массива, указывает на приэкваториальное положение Сибири 700 млн лет назад.

Работа выполнена при поддержке проекта РНФ №19-77-10048.

\section{Список литературы:}

1. Владыкин Н.В., Котов А. Б., Борисенко А. С., Ярмолюк В. В., Похиленко Н. П., Сальникова Е. Б., Травин А. В., Яковлева С. З. Возрастные рубежи формирования щелочно-ультраосновного массива Томтор: результаты геохронологических $\mathrm{U}-\mathrm{Pb}-$ и 40 Ar- 39 Ar-исследований // Доклады Академии наук. 2014. № 2. С. 195-199.

2. Pasenko A., Ivanov A., Malyshev S., Travin A.: Geochronological and paleomagnetic studies of small carbonatite intrusions of the Udzha uplift (Tomtor massif, northeast of the Siberian platform) // EGU General Assembly 2021, online, 19-30 Apr 2021, EGU21-12614, https://doi.org/10.5194/egusphere-egu21-12614, 2021.

Докладчик: Пасенко Александр Михайлович, н.c., pasenkoal@ya.ru 


\section{ЭКСПЕРИМЕНТАЛЬНОЕ СРАВНЕНИЕ ГНСС ПРИЁМНИКОВ И ГНСС} АНТЕНH

Передерин Ф.В. ${ }^{1}$, Розенберг Н.К. ${ }^{2}$, Алёшин И.М. ${ }^{1}$, Иванов С.Д. ${ }^{1}$, Холодков К.И. ${ }^{1}$

${ }^{1}$ ИФЗ РАН, Лаборатория геоинформатики (501)

${ }^{2}$ ИФЗ РАН, Лаборатория спутниковых методов изучения геофизических проиессов (203)

ГНСС-оборудование является неотъемлемой частью БПЛА. Главное его назначение - максимально точная фиксация траектории БПЛА, позиция аппарата принципиально важна для привязки всех проводимых геофизических измерений. Для использования на БПЛА необходимо минимизировать вес оборудования на борту. Требуется ориентироваться в первую очередь на энергоёмкость и вес приёмника и антенны.

Для наших задач нет необходимости вести учет местоположения БПЛА в реальном времени, поэтому оно определяется постобработкой данных. В настоящее время применяется две основных технологии уточнения местоположения, полученного на основе сигналов ГНСС. Первая - технология высокоточного позиционирования РРР (Precise Point Positioning) [1]. Вторая - метод относительного позиционирования по измерениям фазы несущей - статический и кинематический. В статическом режиме работает наземный прибор, который в дальнейшем используется как базовая станция (БС) для БПЛА, а в кинематическом режиме работает БПЛА.

Для исследования качества позиционирования с помощью данного оборудования и сравнения с высокоточным геодезическим оборудованием был проведен эксперимент, суть которого состояла в комбинации приемников и антенн разных типов друг с другом и сопоставлении результатов наблюдений с использованием разных методов постобработки данных.

В эксперименте были задействованы следующие инструменты: геодезическая аппаратура - приёмник Javad Maxor и Javad Alpha, две антенны Javad MarAnt+, и портативная аппаратура - приёмник drotek DP0601 GNSS RTK (F9P) на базе модуля ublox ZED F9P и антенна u-blox ANN-MB-00.

Особенность состояла в том, что в одном из геодезических приёмников (Javad Alpha) и в портативном приёмнике u-blox ZED F9P использовалась система регистрации, разработанная в ИФЗ РАН [2].

По результатам эксперимента проведено сравнение и сформулированы некоторые рекомендации по использованию данной аппаратуры для БПЛА.

Работа выполнена в рамках тем государственного задания ИФЗ РАН.

\section{Список литературы:}

1. Спесивиев А. А., Михайлов П. С., Погорелов В. В., Алёшин И. М., Иванов С. Д., Передерин $\Phi$. В., Холодков $К$. И. Экспериментальное исследование методики высокоточного навигационного обеспечения, основанного на технологии precise point positioning, с использованием автомобиля-лаборатории // Наука и технологические разработки. 2020. Т. 99. №4. С. 53-68.

2. Передерин Ф. В., Алёшин И. М., Иванов С. Д., Михайлов П. С., Погорелов В. В., Холодков К. И. Портативный комплекс регистрации сигналов ГНСС с высокой частотой опроса: полевые испытания и перспективы применения // Наука и технологические разработки. 2018. Т. 97. № 4. С. 28-40

Докладчик: Передерин Федор Викторович, н.c, crash@ifz.ru 


\section{РЕЗУЛЬТАТЫ ЧИСЛЕННОГО МОДЕЛИРОВАНИЯ ВЫСОТНОГО \\ РАСПРЕДЕЛЕНИЯ ИНТЕНСИВНОСТИ ИОНООБРАЗОВАНИЯ В АТМОСФЕРНОМ ПОГРАНИЧНОМ СЛОЕ, ПРОИЗВОДИМОГО ГАММА-КВАНТАМИ РАДИОНУКЛИДОВ ЗЕМНОЙ КОРЫ \\ Прохорчук А.А., Галиченко С.В., Анисимов С.В.}

ГО «Борок» ИФЗ РАН, Лаборатория геофизического мониторинга, пос. Борок

Эффективность и полярность конвективного электрического генератора «хорошей погоды» во многом зависит от факторов, формирующих вертикальное распределение электропроводности атмосферы [1], в том числе, интенсивности образования легких аэроионов вследствие каскадного взаимодействия электронных оболочек атомов с квантами электромагнитного излучения высоких энергий, основными источниками которых в атмосферном пограничном слое являются естественные радиоактивные элементы, содержащиеся в верхнем слое земной коры.

C помощью программного инструментария «Geant4» [2] формулируется и численно решается методом Монте-Карло задача о нахождении вертикального распределения дозы ионизирующей радиации, в которой источником гамма-квантов служит объем почвы в форме правильного гексаэдра, граничащий 5 гранями со слоем почвы и одной гранью - с атмосферой. Почва моделируется, как смесь сложных веществ в варьируемом соотношении. Энергетический спектр гамма-излучения источника формируется из спектров нестабильных изотопов в цепочках распада урана-238 и тория232 , концентрации которых находятся в секулярном равновесии.

В результате моделирования получены вертикальные профили интенсивности ионообразования в нижней атмосфере гамма-квантами радиоактивных рядов урана-238 и тория-232 до высоты 1 км.

\section{Список литературы:}

1. Mid-latitude convective boundary layer electricity: A study by large-eddy simulation / S. $V$. Anisimov, S.V. Galichenko, A.A. Prokhorchuk, K.V. Aphinogenov // Atm. Res. 2020. V. 244. Iss. May. P. 105035.

2. Geant4-a simulation toolkit / S. Agostinelli, J. Allison, K. Amako, J. Apostolakis et al. // Nuclear Instruments and Methods in Physics Research Section A: Accelerators, Spectrometers, Detectors and Associated Equipment. 2003. V. 506. Iss. 3. P. 250-303.

Докладчик: Прохорчук Александр Андреевич, м.н.c., alexprok@borok.yar.ru 


\section{ОСОБЕННОСТИ МЕТОДИКИ МНОГООКОННОГО СИНХРОННОГО МОНИТОРИНГА ВРЕМЕННОЙ ИЗМЕНЧИВОСТИ МТ/МВ ПЕРЕДАТОЧНЫХ ОПЕРАТОРОВ}

Родина Т.А., Варенцов И.М., Лозовский И.Н.

Центр геоэлектромагнитных исследований ИФЗ РАН

Исследования временной изменчивости магнитотеллурических (MT) и магнитовариационных (MB) передаточных операторов успешно ведутся при изучении неоднородностей возбуждения естественного ЭМ поля Земли [1,2] и динамики искажающего влияния индустриальных ЭМ шумов [3]. Методика оценивания передаточных операторов основана на получении частных оценок для отдельных отрезков (окон) записей и их отбраковке по когерентностным и иным критериям. Оценивание ведется независимо для набора окон увеличивающейся длины и серии удаленных точек с последующим многоуровневым робастным осреднением (первичным - прошедших отбраковку частных оценок для окна фиксированной длины, многооконным - итоговых результатов для разных окон и мульти-RR - результатов для разных RR точек).

B данном исследовании частные оценки становятся объектом специального изучения, направленного на диагностику временной изменчивости передаточных операторов в следствие изменения структуры земной коры. Анализу подлежит последовательность всех частных оценок для последовательности окон фиксированной длины. Выбор размера временных окон осуществляется в соответствии с временным масштабом изучаемых явлений $[3,4]$. В программной системе PRC_MTMV $[1,4]$ отбраковка частных оценок осуществляется «вслепую» по формализованным критериям, поэтому для более детального изучения малых вариаций ЭМ поля, были разработаны инструменты для визуализации этой процедуры. Наглядность процедуры отбраковки заметно повышает точность настройки ее параметров, что имеет критическое значение при исследовании эффектов низкой интенсивности.

Учет синхронных наблюдений и ошибок определения частных оценок передаточных операторов позволяет избежать недостоверных выводов об эффектах сейсмических событий на временных интервалах с высоким уровнем ЭМ помех. Полученные результаты указывают на необходимость проведения исследований в области МТ/MB мониторинга геодинамических процессов исключительно на базе синхронных систем наблюдения с углубленным контролем погрешностей получаемых данных.

\section{Список литературы:}

1. Варенцов Ив.М., Соколова., Мартанус Е.P. и др. Методика построения передаточных операторов ЭМ поля для массива синхронных зондирований BEAR // Физика Земли. 2003. № 2. С. 30-61.

2. Варенцов Ив.М., Соколова E.Ю., Рабочая групnа проекта BEAR. Диагностика и подавление авроральных искажений передаточных операторов ЭМ поля в эксперименте BEAR // Физика Земли. 2003. № 4. С. 21-48.

3. Sokolova E.Yu., Varentsov Iv.M., EMTESZ-Pomerania WG. RRMC technique fights highly coherent EM noise in Pomerania // Protokoll uber das 21 Kolloquium "Eiektromagnetische Tiefenforschung. Potsdam: Dtsch. Geophys. Ges. 2005. P. 124-136.

4. Varentsov Iv.M. Arrays of simultaneous EM soundings: design, data processing, analysis, and inversion // Electromagnetic sounding of the Earth's interior: theory, modeling, practice. Amsterdam: Elsevier. 2015. P. 271-299. http://dx.doi.org/10.1016/B978-0-444-635549.00010-6

Докладчик: Родина Татьяна Андреевна, н. с., whittakeresq@gmail.com 


\section{ОПРЕДЕЛЕНИЕ ОРИЕНТАЦИИ ТРЕЩИН В РАЗЛИЧНЫХ МАСШТАБАХ С ИСПОЛЬЗОВАНИЕМ ТЕОРИИ ЭФФЕКТИВНЫХ СРЕД \\ Рязанова М.В., Баюк И.О.}

ИФЗ РАН, Лаборатория фундаментальных проблем нефтегазовой геофизики и геофизического мониторинга (202)

В разведочной геофизике очень важно оценивать ориентацию трещин, т.к. трещины являются каналами для движения углеводородов. Эта задача актуальна для всех масштабов, включая керн, каротаж и сейсмический масштаб.

Для решения этой задачи мы рассчитываем скорости упругих волн (а также их акустический и сдвиговый импедансы, $\mathrm{Vp} / \mathrm{Vs})$, распространяющиеся в разных направлениях в трещиноватой среде, а затем сравниваем их с упругими параметрами матрицы без трещин, чтобы оценить эффект разрушения.

Мы используем методы теории эффективных сред, которые связывают параметры микроструктуры породы и измеренные упругие свойства. Классическими методами теории эффективных сред для трещинноватых сред являются модели Хадсона [1], Эшелби-Ченга [2] и метод самосогласования [3]. Первые два метода работают для изотропной матрицы со включениями с изотропными свойствами флюида, метод самосогласования работает для анизотропной матрицы, и даже для анизотропного материала включений.

Рассматривается трещиноватая горная порода, представленная карбонатной матрицей с одной ориентированной системой трещин. Мы предполагаем, что все трещины имеют одинаковое аспектное отношение, заполнены одним и тем же флюидом (пластовой водой, нефтью, газом или их смесью). Упругие свойства жидко-газовой смеси рассчитываются по уравнению Вуда, которая предполагает равновесие давления в смеси в пределах трещины.

Эффективные свойства горных пород с заполненными жидкостью пустотами рассчитываются по-разному на низких и высоких частотах. Для случая высоких частот применяется так называемая высокочастотная замена жидкости, предполагающая одноэтапные расчеты с заполненными жидкостью трещинами. В сейсмическом масштабе обычно используются формулы пороупругости Брауна-Корринга[4].

Таким образом, в данной работе рассматривается применимость теории методов эффективных сред и рассматривается возможность обнаружения трещин при различном содержании флюидов при разных углах наклона в различных масштабах исследований.

\section{Список литературы:}

1. Hudson J.A. Overall properties of a cracked solid // Mathematical Proceedings of the Cambridge Philosophical Society, 1980, 88, 371-384.

2. Cheng C.H. Crack models for a transversely anisotropic medium // Journal of Geophysical Research, 1993, 98, 675-684.

3. Willis J. Bounds and self-consistent estimates for the overall properties of anisotropic composites // Journal of Mechanics and Physics of Solids, 1977, 25, 185-202.

4. Brown R. and Korringa J. On the dependence of the elastic properties of a porous rock on the compressibility of the pore fluid // Geophysics, 1975, 40, 608-616.

Докладчик: Рязанова Мария Валерьевна, аспирант, ryazanovamasha@yandex.ru 


\section{НЕКОТОРЫЕ ОСОБЕННОСТИ ЗОН СУБДУКЦИИ В ЭПИЦЕНТРАЛЬНЫХ ЗОНАХ СИЛЬНЕЙШИХ ЗЕМЛЕТРЯСЕНИЙ ТИХООКЕАНСКОГО ПОЯСА Семка М.A. ${ }^{1,2}$}

${ }^{1}$ ИФЗ РАН, Лаборатория сейсмической опасности (302)

${ }^{2}$ Институт теории прогноза землетрясений и математической геофизики Российской академии наук

Рассматриваются сильнейшие землетрясения Тихоокеанского сейсмического пояса за период с 1900 -2020 гг. События были разделены на две группы, в первую их которых вошло 15 землетрясений с $\mathrm{M} \geq 8.5$, а во вторую - 58 землетрясений с $\mathrm{M}=8.0-8.4$. Землетрясения Тихоокеанского пояса обусловлены субдукцией Тихоокеанской плиты под прилегающие континенты и островные дуги. Цель данного исследования определить некоторые особенности тех участков зон субдукции, с которыми связаны рассматриваемые землетрясения. Для проведения такого анализа были изучены вертикальные сейсмофокальные разрезы, построенные в эпицентральных областях всех 73-х рассматриваемых землетрясений. На основе разреза для области каждого землетрясения был определен угол наклона погружающейся плиты. Рассматривался угол под которым Тихоокеанская литосферная плита пододвигается под континент относительно горизонта. Анализ проведен на основе одномерных распределений всех событий относительно угла наклона сейсмофокальной зоны. В результате проведенного анализа установлено, что в районах 12 из 15 -ти (или $80 \%$ ) землетрясений с $\mathrm{M} \geq 8.5$ угол наклона погружающейся плиты равен или превышает 40 градусов. Тогда как для абсолютного большинства (83\%) мест землетрясений с $\mathrm{M}=8.0-8.4$, угол наклона сейсмофокальной зоны меньше 40 градусов. Полученные результаты свидетельствуют, что в зависимости от угла наклона сейсмофокального разреза в зонах субдукции Тихоокенского пояса могут быть выделены области разного сейсмического потенциала.

Помимо угла наклона зоны субдукции, в эпицентральных областях рассматриваемых землетрясений были определены значения ряда других параметров, которые могут характеризовать отдельные факторы, обуславливащие сейсмичность, в частности, интенсивность новейших тектонических движений, свойства среды, геометрию и кинематику разломов, а также особенности глубинного стороения. Были определены значения параметров, основанные на морфометрических показателях и характеристиках гравитационного и магнитного полей. Совокупность этих параметров будет проанализирована с помощью алгоритмов распознавания образов (Горшков, 2010) для поиска характерных геолого-геофизических признаков, которые отличают места землетрясений с $\mathrm{M} \geq 8.5$ от мест, где происходили землетрясения с $\mathrm{M}=8.0-8.4$.

\section{Список литературы:}

1. Горшков А.И. Распознавание мест сильных землетрясений в Альпийско-Гималайском поясе. М.: КРАСАНД, 2010. 472c.

Докладчик: Семка Максим Андреевич, м.н.с., khemul1996@mail.ru 


\section{ПРЕДВАРИТЕЛЬНЫЕ РЕЗУЛЬТАТЫ ИЗУЧЕНИЯ НОВЕЙШЕЙ АКТИВНОСТИ ОСТРОВОВ УРУП И ЧИРПОЙ ПО ИТОГАМ ЭКСПЕДИЦИИ «ВОСТОЧНЫЙ БАСТИОН - КУРИЛЬСКАЯ ГРЯДА 2021» \\ Сенцов А.А., Агибалов А.О.}

ИФЗ РАН, Лаборатория методов прогноза землетрясений (702)

В ходе полевых тектонофизических наблюдений на острове Уруп выполнены массовые замеры трещиноватости неогеновых вулканических образований. Эти комплексы представлены лавами андези-базальтов, базальтов и их туфов с включениями обломков дацит-риолитового состава (Натальинская свита $\left(\mathrm{N}_{2} n t l\right)$ ) и лавами адезитов, базальтов и лавобрекчий (Урупская свита $\left(\mathrm{N}_{1} u r\right)$ ), в которых встречаются плиоценовые дайки основного состава, а также экструзиями кварцитовых дацитов миоценового возраста $\left(\zeta \mathrm{N}_{1}\right)$ [1]. Обработка замеров в программе Stereonet [2] показала, что в каждой точке наблюдения ориентировка трещин закономерна: в одних случаях они представляют собой круто падающие трещины отрыва, образовавшиеся в условиях горизонтального растяжения, в других - расположены как сопряженные трещины скалывания в модели Кулона-Андерсона [3]. Эта особенность указывает на тектоническую природу трещин, по данным анализа которых реконструированы ориентировки главных нормальных осей напряжений, существенно различающиеся на территории небольшого по площади острова. Полученные результаты свидетельствуют о сложности новейших геодинамических процессов, реализующихся в разных локальных стресс-состояниях. Установлено, что все изученные нами трещины отличаются доминирующими направлениями простирания, соответствующими диагональной системе планетарной трещиноватости, образованной из-за воздействия скалывающих напряжений [4]. Аналогичная закономерность проявлена в ориентировке линейных элементов рельефа.

Кроме того, на Тихоокеанском побережье полуострова Кастрикум нами выявлены дислокации в рыхлых четвертичных отложениях. Возможно, они образовались из-за цунамических заплесков с высотой волны около 9-12 м. В районе залива Наталья в шурфе на глубине 1,75 м в прослое песков обнаружена древесина, которая может быть принесенной волной цунами высотой около 6 м (при глубине заплеска порядка 300 м).

В ходе детальных геолого-геоморфологических наблюдений описаны ранее не изученные фумарольные поля на восточном склоне вулкана Черного (остров Чирпой).

Работа выполнена в рамках госзадания ИФЗ РАН, а также Комплексной экспедищии РГО и Миноборонь РФ.

\section{Список литературы:}

1. Полеи А.Ю., Злобин Т.К. Оценка напряженного состояния земной коры и верхней мантии в районе Южных Курильских островов // Тихоокеанская геология. 2014. Т. 33. № 2. C. $64-75$

2. Allmendinger R.W., Cardozo N.C., Fisher D. Structural geology algorithms: Vectors \& Tensors. Cambridge: Cambridge University Press. 2012. 302 p.

3. Anderson E.M. The Dynamics of Faulting // Trans. Edinburgh Geol. Soc. 1905. V. 8. No. 3. P. 387-402.

4. Каттерфельд Г.Н., Чарушин Г.В. Глобальная трещиноватость Земли и других планет // Геотектоника. 1970. № 6. С. 3-14.

Докладчик: Сенцов Алексей Андреевич, н.c., alekssencov@yandex.ru 


\section{РОЛИ ПИАР СПЕЦИАЛИСТОВ В НАУЧНЫХ ОРГАНИЗАЦИЯХ НА ПРИМЕРЕ ИФЗ РАН \\ Старикова А.Ю.}

МГУ, философский факультет, направление «Реклама и связи с

общественностью», ИФЗ РАН, департамент по связям с общественностью.

Сегодня популяризация науки является одним из ключевых направлений в Российской Федерации. 2021 год объявлен годом науки и технологий, а с 2018 года ведется государственная программа «Развитие науки и технологий», обозначенная Постановлением Правительства Российской Федерации от 29.03.2018 № 346 [1].

В институте, как и во многих других исследовательских организация, был открыт департамент по связям с общественностью, который реализует задачи по освещению работы учёных в медиапространстве. За последний год у института появились социальные сети, в которых публикуется научно-популярный контент, создающийся на основании материалов организации. Сотрудники департамента повышают узнаваемость организации, участвуя в профильных выставках и мероприятиях, например, в Metrol Ехро-2021. Это помогает найти заказчиков на выполнение работ, связанных с профилем института, а также привлечь молодую аудиторию в аспирантуру для формирования кадрового резерва организации.

Помимо популяризации деятельности ИФЗ РАН, сотрудники департамента помогают учёным в экспедициях. Например, делают аэрофотосъёмку геологических объектов, что позволяет в детальнее их изучать. Помимо этого, сотрудники департамента первые в России стали проводить прямые эфиры из экспедиций ИФЗ РАН на платформе Instagram.

Роль пиар-специалиста в науке очень значима и высока, поскольку они являются ретрансляторами научного знания на широкую аудиторию [2]. За последние 3 года реализации государственной программы «Развитие науки и технологий» к популяризации науки было подключено множество научных организаций, в том числе ИФ3 РАН. Динамика в работе данного направления положительная. Аудитория в медийном пространстве заинтересована в получении научных знаний о геофизике, геологии и других направлениях деятельности института в научно-популярной форме. «Исследования в сфере научной коммуникации необходимы для того, чтобы у отечественной науки было достойное, резонансное «завтра», говорит в одной из своих работ Сайко Елена Анатольевна, главный научный сотрудник, зав. отделом ФГБУ науки «Научный и издательский центр «Наука» РАН» [3].

\section{Список литературы:}

1. Портал госпрограмм РФ// электронный ресурс. Ссылка: https://programs.gov.ru/Portal/program/14/passport

2. Сафонова A.C. // Проблемы и достижения в научной сфере// электронный ресурс. Ссылка:https://cyberleninka.ru/article/n/nauchnye-kommunikatsiy-v-rossii-problemy-iperspektivy/viewer

3. Сайко E. A. // Научные коммуникации в России: реалии и перспективы исследований/ электронный ресурс. Ссылка: https://nppir.ru/PDF/01NP515.pdf

Докладчик: Старикова Анастасия Юрьевна, специалист по связям с общественностью, staraus1119@yandex.ru 
АКТИВНАЯ ТЕКТОНИКА И ПАЛЕОСЕЙСМИЧНОСТЬ ВДОЛЬ КРАЕВОГО И АДЫРНЫХ РАЗЛОМОВ СЕВЕРНОЙ ЧАСТИ ИССЫК-КУЛЬСКОЙ КОТЛОВИНЫ (КЫРГЫЗСТАН, ТЯНЬ-ШАНЬ)

Стрельников А.А. ${ }^{1}$, Абдиева С.В. ${ }^{2}$, Старикова А.Ю. ${ }^{3}$, Корженков А.М. ${ }^{1}$

${ }^{1}$ ИФЗ РАН, лаборатория палеосейсмологии и палеогеодинамики №304, Россия, Москва

${ }^{2}$ Институт коммуникаџий и информаџионных технологий КРСУ, Кыргызстан, Бишкек

${ }^{3}$ МГУ им. М.В. Ломоносова, философский факультет, кафедра философии языка и коммуникации, магистр; ИФЗ РАН, департамент по связям с общественностью, Россия, Москва

Горная система Тянь-Шань является одной из составляющих ГималайскоСредиземноморского подвижного пояса. Возникновение Тянь-Шаньского орогена объясняется следствием столкновения и продолжающейся коллизией Евроазиатской и Индийской литосферных плит [1]. Величина сокращения земной коры вкрест простирания горной системы составляет сантиметры в год [2], что объясняет контрастный рельеф гор и высокую сейсмическую активность.

В сентябре 2021 г. нами были проведены палео- и археосейсмологические исследования внутригорных поднятий и депрессий на севере Иссык-Кульской котловины: участки на северном побережье Прииссыккулья ограниченные курортножилой зоной (село Чырпыкты, село Тамчы, село Чон-Сары-Ой, город Чолпон-Ата, село Бостери, село Григорьевка, село Семёновка, село Ананьево, село Орто-Орюктю). Так, например, выше села Ашхабак в предгорье была обнаружена субширотная долина, представляющая из себя ромбовидный рамповый грабен, ограниченный с севера и юга сдвиго-надвиговыми дизъюнктивами. Были произведены тренчинговые работы через указанные разломы, а также крупномасштабная аэрофотосьемка исследуемого участка. Зафиксировано разрушение древней ирригационной системы, а также деформации мегалитического комплекса. Установлена повторяемость сильных землетрясений по изученным дизъюнктивам, в упомянутых траншеях отобраны пробы на радиоуглеродный анализ. Установлено наличие сдвигов, надвигов и поддвигов в зонах Аксуйского краевого и адырных разломов, ответственных за возникновение неизвестных до сей поры сильных сейсмических катастроф прошлого.

\section{Список литературы:}

1. Molnar P., Tapponier P. Cenozoic tectonics of Asia: Eff ects of a continental collision // Science. 1975. V. 189, P. 419-426.

2. Zubovich A.V., Wang X., Scherba Yu.G., Schelochkov G.G., Reilinger R., Reigber C., Mosienko O.I., Molnar P., Michajljow W., Makarov V.I., Li J., Kuzikov S.I., Herring T.A., Hamburger M.W., Hager B.H., Dang Y., Bragin V.D., Beisenbaev R.T. GPS velocity fi eld for the Tien Shan and surrounding regions // Tectonics. 2010. V. 29, TC6014. https://doi.org/ 10.1029/2010TC002772

Докладчик: Стрельников Андрей Андреевич, маг., н.c., aas@ifz.ru 


\section{НОВЕЙШАЯ ГЕОДИНАМКА БОЛЬШОГО КАВКАЗА \\ Фадеева К.В.}

Московский государственный университет им. М.В. Ломоносова

Большой Кавказ на новейшем этапе своего развития испытывает активный рост (25 км за последние 10 млн. лет, соответственно средние скорости - 2-5 мм/год) и вовлекает в поднятие прилегающие предгорные впадины. Этот рост сопровождается высокой сейсмической активностью, что в свою очередь всегда являлось актуальной проблемой по обеспечению безопасности населения, которое проживает преимущественно в западной и восточной части Кавказа.

Основной целью работы являлось установление связи между структурногеоморфологическими и геодинамическими параметрами с сейсмичностью Большого Кавказа. В работе были изучены особенности неотектоники и сейсмичности Большого Кавказа, построена структурно-геоморфологическая карта, произведен корреляционный анализ рассчитанных структурно-геоморфологических (кривизна рельефа, уровень удаленности от линеаментов), геодинамических параметров (напряженное состояние пород, направление максимального напряжения, вероятность образования новых малых разрывных нарушений) и сейсмичности, создана модель механизма образования землетрясений на территории Большого Кавказа.

В работе используется структурно-геоморфологический анализ, который помог выделить линеаменты (слабые зоны) на территории Большого Кавказа. Новейшие структуры, сохраняющие простирание крупных структур фундамента и осадочного чехла, например, крупных разломов фундамента, фрагментарно отражаются в рельефе в виде линеаментов, блоков, поднятий и впадин [1]. Построение параметров и расчеты взаимосвязи проводились с помощью специального программного обеспечения.

На основе полученных данных можно сделать вывод, что с глубиной связь выраженности в рельефе межу плотностью землетрясений и амплитудами рельефа постепенно уменьшается, так как меняется характер параметров и местоположение основных структур. Полученное соотношение напряженного состояния может быть связано с внедрением коро-мантийного вещества [2], из-за которого верхняя часть испытывает растяжения, а более глубинные уровни - сжатие.

\section{Список литературы:}

1. Панина Л.В. Новейшие структуры и рельеф земли. Москва: Издательство «Перо», 2019. $115 \mathrm{c}$;

2. Маринин А.В., Расиветаев Л.М. Структурные парагенезы СевероЗападного Кавказа // Проблемы тектонофизики. К сорокалетию создания М.В. Гзовским лаборатории тектонофизики в ИФЗ РАН. - ИФЗ РАН, 2008. — с. 191-224.

Докладчик: Фадеева Карина Васильевна, студент, kfv036@gmail.com 


\section{ПОСТРОЕНИЕ ГЛАВНЫХ ОСЕЙ СЖАТИЯ И РАСТЯЖЕНИЯ ПО СВЕТОДАЛЬНОМЕРНЫМ ДАННЫМ НА КАМЧАТСКОМ ГЕОДИНАМИЧЕСКОМ ПОЛИГОНЕ МЕТОДОМ ТЕНЗОМЕТРИЧЕСКОГО АНАЛИЗА \\ Фатmахов E. $A$.}

ИФЗ РАН, Лаборатория «Современной и прикладной геодинамики» (201)

Целью данной работы являлось проведение тензометрического анализа по прецизионным светодальномерным данным на Камчатском геодинамическом полигоне. В результате анализ длительных рядов прецизионных наблюдений, с привлечением знаний о тектонике плит и направлениях движений этих плит, сделал возможным вычисление направлений главных осей сжатия и растяжения в зонах сочленения с помощью тензометрического анализа [1]. В качестве факторов, задающих доминирующую ось нагружения (воздействия), предложены два источника воздействия - магматизм (близко расположенные активные вулканы) и зона субдукции (воздействие от погружения Тихоокеанской плиты).

Учитывая, что Камчатка это сейсмоактивный регион, то при анализе учитывались сильные $(M>5.5)$ землетрясения для выявления возможной связи между землетрясениями и характеристиками деформационного процесса $[2,3,4,5]$.

Статистическая обработка исходных данных, а также спектральный анализ проводился в пакете WinABD [6, 7].

Работа выполнена в рамках государственного задания Института Физики Земли им. О. Ю. Шмидта РАН.

\section{Список литературы:}

1. Кузьмин Ю. O., Фаттахов E. A. Тензометрический метод анализа результатов наблюдений на геодинамических полигонах // Маркшейдерский вестник. 2016. № 5. С. $22-25$.

2. Кузьмин Ю.О., Чуриков В.А. Механизм формирования аномальных деформационных процессов в период подготовки Камчатского землетрясения 2 марта 1992 г. // Вулканология и сейсмология. 1998. №6. С. 37-51.

3. Churikov V.A., Kuzmin Yu.O. Relation between deformation and seismicity in the active fault zone of Kamchatka, Russia // Geophysical Journal International, (1998), v.133, pp. 607614.

4. Кузьмин Ю. О. Парадоксы сопоставительного анализа измерений методами наземной и спутниковой геодезии в современной геодинамике // Физика Земли. 2017. №6. С. 24 39.

5. Кузьмин Ю. О., Фаттахов Е. А. Анализ повторных нивелирных наблюдений в зонах разломов методами теории деформаций // Вестник СГУГиТ (Сибирского государственного университета геосистем и технологий). 2018. Т. 23. № 4. С. 67-84.

6. Фаттахов E.A. Спектрально-временной анализ светодальномерных наблюдений на Камчатском и Ашхабадском геодинамических полигонах Вестник СГУГиТ (Сибирского государственного университета геосистем и технологий). 2017. Т. 22. № 4. С. 5-17.

7. Дещеревский А.В., Сидорин А.Я., Фаттахов Е.А. Комплексная методика описания и фильтрации экзогенных эффектов в данных мониторинга, учитывающая вид наблюдений и дефекты экспериментальных данных // Наука и технологические разработки. 2019. Т. 98. № 2. С. 25-60.

Докладчик: Фаттахов Евгений Альбертович, н.c., fea@ifz.ru 


\section{ПОЗДНЕПАЛЕОЗОЙСКИЙ ЭТАП ФОРМИРОВАНИЯ СЕВЕРНОГО СЕГМЕНТА ЦЕНТРАЛЬНО-АЗИАТСКОГО СКЛАДЧАТОГО ПОЯСА: ПАЛЕОМАГНИТЫЕ ОГРАНИЧЕНИЯ \\ Федюкин И.В.}

ИФЗ РАН, Лаборатория Археомагнетизма и эволюичи магнитного поля Земли №106

Данная работа посвящена расшифровке геодинамической эволюции северного сегмента Центрально-Азиатского складчатого пояса (ЦАСП) в пермское время. В работе проанализированы пермские палеомагнитные данные Сибирского, ВосточноЕвропейского, Казахстанского, Таримского и Джунгарского кратонов, обрамляющих ЦАСП. В пределах складчатого пояса выявлены ключевые магматические события, связанные с формированием каркаса ЦАСП, и проанализированы догерцинские складчатые области, деформации которых были активизированы в позднегерцинское время.

Анализ пермских палеомагнитных данных по каждому кратону указывает на наличие конвергентных смещений за счет относительного вращения блоков. Сибирский кратон вращается по часовой стрелке относительно Восточно-Европейской платформы, при этом полюс вращения располагался в пределах Карского моря, а сокращение пространства происходит за счет сближения южных (в современных координатах) частей платформ, что приводило к многочисленным деформациям и формированию (преимущественно) левосторонних сдвигов и надвигов вдоль основных разломов АлтаеСаянской горной области с амплитудой движения до тысячи километров. Казахстанский блок претерпел существенные деформации с образованием ороклина - восточная часть блока смещалась относительно западной (в современных координатах) против часовой стрелки; Джунгарский блок располагался у восточной окраины Казахстанского кратона и выступал индентором, приводящим к ороклинному изгибу Казахстана и участвовал в формировании Алтайской сдвиговой зоны.

Для визуализации относительных движений крупных кратонов, а также подвижных областей в составе северного сегмента ЦАСП был создан гис-проект на базе тектонической карты России и сопредельных территорий. На основании палеомагнитных данных подготовлены реконструкции для кратонов. В результате анализа литературы для основных структурных единиц в пределах складчатой области указывались имеющиеся данные (геодинамическая характеристика, кинематика, временные ограничения).

В пермское время северный сегмент ЦАСП испытывал крупноамплитудные горизонтальные смещения по системам сдвигов и надвигов, приводящие к вращениям подвижных областей. К началу мезозоя был сформирован основной каркас складчатой области, конфигурация которой была близка к современной.

Докладчик: Федюкин Иван Владимирович, н.c., ivan.fedyukin@gmail.com 
ИССЛЕДОВАНИЕ МАГНИТНОЙ ТЕКСТУРЫ С ЦЕЛЬЮ ОПРЕДЕЛЕНИЯ НАПРАВЛЕНИЯ ТЕЧЕНИЯ МАГМЫ НА ПРИМЕРЕ РАЗНОВОЗРАСТНЫХ ДАЕК МУРМАНСКОГО КРАТОНА (КОЛЬСКИЙ ПОЛУОСТРОВ)

Фурсова С.А. ${ }^{1,2}$, Веселовский Р.В.,

${ }^{1}$ ИФЗ РАН, Лаборатория Археомагнетизма и эволюичи магнитного поля Земли (106)

${ }^{2}$ Московский государственный университет им. М. В. Ломоносова

В настоящий момент одним из наиболее актуальных вопросов в геологии является развитие представлений о геологической эволюции древних платформ. Актуальность данного направления связана с возможностью понимания геодинамики и тектоники кратонов с использованием многочисленных современных методов, в том числе при помощи изучения петромагнитных характеристик (магнитной текстуры) интрузивных комплексов. В России данный метод применяется не так активно, как за рубежом, именно поэтому данная работа может быть актуальна для продолжения внедрения метода анизотропии магнитной восприимчивости (AMB) в российскую практику.

Исследование магнитной текстуры активно используется для пополнения знаний об эволюции плюм-литосферных процессов с помощью реконструкции направления течения магматического расплава в интрузивных телах (дайках, силлах) на основании ориентировки главных осей эллипсоида АМВ.

В рамках данной работы были проведены измерения АМВ образцов разновозрастных (неоархейских, протерозойских и девонских) базитовых даек северовосточной части Мурманского кратона. Исследованные дайки расположены на максимальной удалённости от активных региональных тектонических зон - орогенов, и представляют уникальную возможность для изучения тектоники и магматизма древних платформ.

Исследования показали, что далеко не все изученные интрузивные тела сохранили первичную магнитную текстуру. Только $40 \%$ из них могут быть использованы для дальнейшей интерпретации направления течения магмы. В соответствии с результатами было выделено несколько групп на каждый этап плюмового магматизма (2.68 млрд. лет, 2.50 млрд. лет, 1.86 млрд.лет, 360-400 млн. лет): отмечается, что во всех перечисленных этапах, кроме девона, магматический очаг был локализован на севере (в современных координатах) или располагался непосредственно под интрузивными телами.

Работа выполнена при поддержке гранта РНФ № 16-17-10260.

Докладчик: Фурсова Софья Андреевна, инженер, fursova.sofia@mail.ru 


\section{ПОДГОТОВКА ОПЕРАТИВНЫХ ГЕЛИОГЕОФИЗИЧЕСКИХ ДАННЫХ ДЛЯ ЦЕНТРА КОСМИЧЕСКОЙ ПОГОДЫ В ИНТЕРЕСАХ БЕЗОПАСНОСТИ АВИАПЕРЕЛЁТОВ}

Холодков К.И. ${ }^{1,3}$, Алёшин И.М. ${ }^{1,2}$, Аракелов А.С. ${ }^{2}$, Буров В.А. ${ }^{2}$, Васильев А.Е. ${ }^{2}$, Иванов С.Д. ${ }^{1,2}$

${ }^{1}$ Институт физики Земли им. О. Ю. Шмидта Российской академии наук, Лаборатория геоинформатики

${ }^{2}$ Институт прикладной геофизики им. Е. К. Федорова Федеральной службь России по гидрометеорологии и мониторингу окружающей средь

Центр космической погоды является информационно-ёмкой системой. Помимо характерных для проведения солнечного синоптического анализа снимков Солнца в различных спектральных диапазонах, а также параметров солнечного ветра, потоков частиц, для выполнения задач предупреждения об опасных эффектах космической погоды требуются также данные сотен наземных станций.

Задача практического применения большого объема оперативных гелиогеофизических данных включает в себя, помимо разработки и внедрения алгоритмов их научной интерпретации, ещё и технические мероприятия по получению и предварительной подготовке этих данных. Поэтому, уже на этапе получения этих данных требуются программное обеспечение, способное принять и обеспечить дальнейшую обработку порядка 100 Гб данных в сутки.

Мы рассмотрим приёмы и технологии, применённые в ходе создании центра космической погоды для организации доставки и представления гелиогеофизических данных. Центральным компонентом в системе является база данных, оптимизированная для работы с временными рядами, а также надстройка, позволяющая удобным образом работать с не-рядами.

Реализованы механизмы, извлекающих данные с обсерваторий и банков данных, в том числе получающие измерения со станций ГНСС. Дальнейшая обработка некоторых типов данных предполагает интерполяцию для создания карт, а также поиск опасных значений.

Докладчик: Холодков Кирилл Игоревич, к. т. н., с. н. с., keir@ifz.ru 


\section{ОЦЕНКА АКТИВНОСТИ ЕСТЕСТВЕННОЙ ТРЕЩИНОВАТОСТИ НА ОСНОВЕ ПОСТРОЕНИЯ ЗД ГЕОМЕХАНИЧЕСКОЙ МОДЕЛИ НЕФТЯНОГО МЕСТОРОЖДЕНИЯ Хуснутдинов Ф.Ф. ${ }^{1,2}$, Нугманов И.И. ${ }^{2}$ \\ ${ }^{1}$ ИФЗ РАН, Лаборатория фундаментальных и прикладных проблем тектонофизики (204) \\ 2 АНО ВО Университет Иннополис}

Для оптимизации технологических операций и контроля рисков на всех этапах освоения месторождения необходимо учитывать напряженно-деформированное состояние горных пород и его изменение в процессе разработки $[1,2]$. Целью работы является создание 3Д геомеханической модели и оценка активности сети естественной трещиноватости на основе теории предельных напряжений. В ходе построения модели использовались данные расширенного комплекса геофизических исследований скважин, лабораторных исследований керна и результаты технологических операций на скважинах. Результаты исследования имеют важное значение для снижения рисков при эксплуатации нефтегазовых активов.

\section{Список литературы:}

1. Гзовский М.В. Основы тектонофизики. - М.: Наука, 1975. -536 с.

2. Zoback M.D. Reservoir geomechanics. - Standford University: Cambridge University Press, 2007. 


\section{ПРИМЕНЕНИЕ РАМАНОВСКОЙ СПЕКТРОСКОПИИ ДЛЯ ЛОКАЛИЗАЦИИ ИСТОЧНИКОВ СНОСА ОБЛОМОЧНОГО ЦИРКОНА \\ Чистякова А.В. ${ }^{1}$, Веселовский Р.В. ${ }^{1,2}$, Семёнова Д.В. ${ }^{3}$ \\ ${ }^{1}$ Московский государственный университет им. М.В. Ломоносова}

${ }^{2}$ Лаборатория Археомагнетизма и эволючии магнитного поля Земли (106), ИФЗ РАН

${ }^{3}$ Институт геологии и минералогии Сибирского отделения РАН, Новосибирск

В рамках исследования зёрен обломочного циркона из докембрийских кварцевых песчаников Ивановского грабена (баренцевоморское побережье Кольского полуострова) опробован метод спектроскопии комбинационного рассеяния (рамановской спектроскопии) для конкретизации питающих провинций по времени проявления в них наложенных термальных событий.

Предварительно для 150 зёрен циркона были получены оценки U-Pb изотопного возраста методом LA-ICP-MS на базе Центра многоэлементных и изотопных исследований ИГМ СО РАН (Новосибирск). Затем была применена методика, детально описанная в [1] и базирующаяся на взаимосвязи параметров рамановского спектра, рассчитанной $\alpha$-дозы излучения и U-Pb изотопного возраста зёрен циркона. Спектроскопия комбинационного рассеяния выполнялась в ЦКП ИФЗ РАН (Москва). Поскольку рамановский анализ выполнялся уже после U-Pb LA-ICP-MS датирования, были исследованы области зёрен, находящиеся на расстоянии не менее 20 мкм от кратера лазерной абляции, но аналогичные по характеру внутренней структуры. Съёмка спектров проводилась с использованием рамановской приставки EnSpectr R532 к прямому оптическому микроскопу Olympus BX53M: лазер 532 нм, мощность 30 мВт, объектив 50x, экспозиция 0.5 с по 20 циклов.

Показано, что большинство проанализированных зёрен циркона характеризуются высокой степенью кристалличности. Однако около $25 \%$ точек анализа значительно отклоняются от этого поля. Путём эмпирического пересчёта дозы излучения, приблизительный возраст термального события, которое частично восстановило кристаллическую структуру этих зёрен, был определен как 1300-1500 млн. лет. При этом наличие неотожженных зёрен циркона исключает возможность температурного воздействия после аккумуляции материала в бассейне осадконакопления, то есть наблюдаемые признаки отжига структуры являются отличительной чертой одного из источников сноса.

Исследования проведены при поддержке грантов Президента РФ МД-1116.2018.5 и РНФ 16-17-10260-П, а также выполнены в рамках НИР по государственному заданию ИФЗ РАН и геологического факультета МГУ имени М.В. Ломоносова. Лабораторные исследования проведены на оборудовании ЦКП «Петрофизика, геомеханика и палеомагнетизм» ИФЗ РАН.

\section{Сиисок литературы:}

1. Resentini A., Andò S., Garzanti E., Malusà M.G., Pastore G., Vermeesch P., Chanvry E. and Dall'Asta M. Zircon as a provenance tracer: Coupling Raman spectroscopy and U-Pb geochronology in source-to-sink studies, Chem. Geol. 2020. V. 555 (119828). https://doi.org/10.1016/j.chemgeo.2020.119828.

Докладчик: Чистякова Альвина Владимировна, магистрант, sinematograf11@yandex.ru 
ОПРЕДЕЛЕНИЕ ТОЛЩИНЫ ЗЕМНОЙ КОРЫ ПО СОСТОЯНИЮ РАВНОВЕСИЯ ЭЙРИ (НА ПРИМЕРЕ ВОСТОЧНОГО УЗБЕКИСТАНА) Шукуров 3.Ф.

Институт Сейсмологии АН РУз, Ташкент

Район исследования расположен между $68^{\circ}-73^{\circ}$ восточной долготы и $40^{\circ}-43^{\circ}$ северной широты, охватывает весь Восточный Узбекистан и является сейсмоактивным регионом. Сейсмическая активность территории Восточного Узбекистана определяется активностью расположенных в нём разломов. Это, в свою очередь, является неразрывной связью с движением и деформацией блоков, которые ограничены разломами в коре.

Состояние равновесия Эйри использовалось для определения глубина до границы Мохоровичича для расчета физических параметров блоков.

Современные экспериментальные данные показывают как наличие вариаций плотности коры в горизонтальном направлении, так и прогибов поверхности Мохоровичича, коррелирующих с рельефом, то есть изостатическое равновесие обеспечивается сочетанием моделей Эйри и Пратта [1].

По равновесию Эйри предполагается, что внешняя оболочка Земли (земная кора) повсюду имеет одинаковую среднюю плотность $\rho_{c}$ и подстилается слоем с более высокой, но также постоянной плотностью $\rho_{m}$ (верхней мантией). Неровный рельеф земной поверхности компенсируется в схеме Эйри обратными по знаку ундуляциями подошвы коры (границы Мохоровичича). Толщина коры, поверхность которой совпадает с уровнем моря, равна $H$. Коровый блок, поверхность которого находится на высоте $h$ над уровнем моря (геоида), имеет легкий “корень” плотностью $\rho_{c}$ и толщиной $r$ [2]:

$$
r=\frac{\rho_{c} h}{\rho_{m}-\rho_{c}}
$$

На основании принципа гидростатического равновесия (закона Архимеда) можно оценить толщину “корня” [2]:

$$
R=h+H+r
$$

Здесь R - толщина земной коры, $h$ - высота хребта, $H$ - толщина земной коры, равная геоиду, $r$ - компенсированная толщина под толщиной земной коры равную геоиду.

Исследования условно разделить область исследований на блоки даёт возможность исследовать активность и деформацию блоков, построить ее модели, количественно оценить геодинамические процессов.

На основании полученных результатов на основе различных программных пакетов можно создавать карту мощности земной коры Восточного Узбекистана и прилегающей территорий.

\section{Список литературы:}

1. Артемьев М. Е. Изостазия территории СССР. Москва: Наука, 1975. 216 с. 2. Аплонов C.В. Геодинамика. Санкт-Петербург: С.-Петерб. ун-та., 2001. 360 с.

Докладчик: Шукуров Зухриддин Фазлиддинович, м.н.c., zukhriddin85@mail.ru 


\section{Оглавление}

Организационный и Программный комитеты Конференции ..............................3

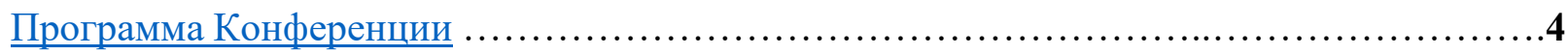

Анализ современной геодинамики Фенноскандии

Агибалов А.О., Сенцов А.А., Бондарь И.В...............................................9

Глобальная модель эволюции Гималайско - Тибетского орогена

Алексеев Р.С., Ребеикий Ю.Л......................................................10

Результаты применения ферроколлоида для создания магнитного контраста при микроскопическом изучении палеомагнитных образцов

Цельмович В.А, Афиногенова Н. А., Бобровникова Е.М., Лебедев И.Е.

Расчет индекса хрупкости по результатам геомеханических испытаний

Бахмач М.М., Баюк И.О, Дубиня Н.В.

Особенности моделирования эффективных упругих свойств карбонатных пород в масштабе керна

Березина И.А.

Напряженность геомагнитного поля в конце мелового суперхрона прямой полярности (по лавовым потокам Охотско-Чукотского вулканического пояса)

Бобровникова Е.М., Лебедев И.Е.

Результаты исследований двух локальных районов в зоне влияния Имандра-Колвицкого разлома (Кольский полуостров)

Бондарь И.В

Влияние внешних факторов на устойчивость самоподъемной буровой установки

Васильев И.А., Дубиня Н.В., Начев В.А., Алексеев Д. А., Тихочякий С.А. 16

Конволюции в четвертичных озерных комплексах Балтийского щита и Якутии, и их сравнение с сейсмитами

Горбатов Е.C.

Новейшее напряженно-деформированное состояние г.Бештау

Гордеев Н.А., Бондарь И.В

Массив синхронных MT/MB зондирований EarthScope: многоточечное оценивание и анализ передаточных операторов в активном регионе северо-запада США

Грачева Д.А., Варенияов Ив.М., Лозовский И.Н..

Исследование сейсмотектонических деформаций о. Сахалин по данным спутниковой геодезии

Гридчина М.С.

Влияние микроструктуры породы и затухания упругих волн на подбор эффетивных параметров в порово-трещинноватых средах

Дамянович Д. И. 
Опорный разрез позднечетвертичных отложений в карьере завода им. Свердлова (Ленинградская обл.) - предварительные результаты полевых работ 2021 г.

Дуданова В.И., Ручкин М.В.

Pmtools: программное обеспечение для анализа палеомагнитных данных

Ефремов И. В., Веселовский Р. В.

О сотрудничестве Института физики Земли им. О.Ю. Шмидта Российской академии наук и

Русского географического общества в 2020 и 2021 годах

Жостков Р.А., Овсюченко А.Н.

Результаты верификации спектрального метода решения обратной задачи сейсмики на численной модели Мармузи

Загорский Д. Л., Преснов Д. А., Жостков Р. А. 25

Применение беспилотных летательных аппаратов в условиях полевых геологических работ

Холодков К.И., Иванов С.Д., Корягин В.Н., Алешин И.М., Холодков И.Н., Морозов

Ю.А., Матвеев М.А.

Энергетическая классификация акустических событий по коде сигнала

Карчева Т.И., Шапиро Н.М., Патонин А.В., Смирнов В.Б., Пономарёв А.В.

Проведение расчета сейсмической интенсивности на участках распространения

скальных грунтов

Кауркин М.Д...... - .

Наблюдения электрического состояния приземной атмосферы и статистические оценки

Климанова Е. В., Анисимов С. В., Галиченко С. В., Афиногенов К. В.

Результаты обработки геологических стресс-индикаторов южной части Кандалакшского залива

Гордеев Н. А., Клоков И. А., Стрельников А. А.

Предварительная интерпретация данных комплексных исследований на акватории Баренцева моря в рейсе TTR-20 (район поднятие Демед)

Королева А.О.

Многоканальное DAQ устройство длительной регистрации акустических данных

Краюшкин Д. В., Кох В. В., Казначеев П. А.

Изучение новейшей геодинамики и уточнение глубинного тектонического строения района озера Маныч-Гудило

Комевой Н.Г., Андреева Н.В.

Сравнительный анализ моделей формирования локальных напряжений в зонах раздвиговых разломов нефтегазоносных регионов

Кузьмин Д. К.

Применение каппаметрии в вопросах корреляции, стратиграфии и геохронологии лёссовопочвенных серий южного Таджикистана

Кулакова Е.П., Мещчерякова О.А., Курбанов Р.Н. 
Определение направлений естественной остаточной намагниченности самоедской свиты в долине p. Верхняя Таловая (Норильский район)

Латанова Е.А., Латышев А.В.

Проблемы стратиграфии и возраста формирования вулканитов северной части ОхотскоЧукотского вулканического пояса

Лебедев И.Е., Тихомиров П.Л.

Исследование начальных этапов деформирования горных пород с помощью циклических многостадийных испытаний

Леонова А.М., Фокин И.В., Гизатуллин Д.М., Егоров Н.А.

Характерные геолого-геофизические признаки рудоносных узлов Кавказа и Алтай-Саянского региона

Ливинский А.И..

Сопоставление результатов измерений методами спутниковой и наземной геодезии на одном из нефтегазовых месторождений Казахстана

Ломоносов М.Д..

Трехмерная модель юга Фенноскандии по данным инверсии приемных функций

Малыгин И. В., Алешин И.М.

Связь новейшего структурного плана Западно-Сибирской плиты с древними дислокациями и месторождениями углеводородов

Мануилова Е.А., Панина Л.В.

Применение метода MASW для выделения геологических опасностей в Печорском море

Марятов А.К., Титов Н.О., Токарев М.Ю., Горбачёв С.В., Гурвич Л.А., Вакуленко

C.A.

Фазовые превращения геоматериала при сейсмических скоростях подвижки

Матвеев М.А., Смульская А.И., Морозов Ю.А.

Исследование постледниковых движений Фенноскандии по зарубежным и российским данным $\underline{\Gamma H C C}$

Мельник Г. Э., Стеблов Г. М.

Нагрузочные числа Лява для различных моделей неоднородной упругости Венеры

Менщикова Т.И.

Первые петромагнитные результаты для лёссово-почвенного разреза Хонако-и (средняя Азия)

Мешерякова О.А., Кулакова Е.П., Курбанов Р.Н..

Подход к построению региональных моделей сейсмического эффекта на примере Байкальского региона

Миронов В.А., Перетокин С.А.

Скачок напряжений в слоистой трансверсально-изотропной среде

Молокоедов А.С 
Исследования влияние малых тангенциальных гравитационных сил на глобальное поле напряжений

Мягков Д.С., Ребеикий Ю.Л.

Исследование неоднозначности решения обратных задач петроупругого моделирования с помощью нейронной сети

Насретдинова Д.И. .51

Исследование распространения трещин в сложных породах-коллекторах на микроуровне

Начев В.А., Турунтаев С.Б.

Нейросетевой прогноз теплопроводности по данным электромагнитных зондирований в геотермальной области Сульц-су-Форе (Франция)

Ненюкова А.И., Спичак В.В.

Анализ пространственно-временных вариаций магнитуды представительной регистрации землетрясений на Камчатке

Павленко В.А., Завьялов А.Д..

Результаты палеомагнитного исследования лампрофиров Томторского щелочного массива (север Сибирской платформы)

Пасенко А.М., Мальишев С.В., Ситкина Д.Р.

Экспериментальное сравнение ГНСС приёмников и ГНСС антенн

Передерин Ф.В., Розенберг Н.К., Алёшин И.М., Иванов С.Д., Холодков К.И.

Результаты численного моделирования высотного распределения интенсивности ионообразования в атмосферном пограничном слое, производимого гамма-квантами радионуклидов земной коры

Прохорчук А.А., Галиченко С.В., Анисимов С.В.

Особенности методики многооконного синхронного мониторинга временной изменчивости МТ/МВ передаточных операторов

Родина Т.А., Варенцов И.М., Лозовский И.Н....

Определение ориентации трещин в различных масштабах с использованием теории эффективных сред

Рязанова М.В., Баюк И.О.

Некоторые особенности зон субдукции в эпицентральных зонах сильнейших землетрясений Тихоокеанского пояса

Семка М.А.

Предварительные результаты изучения новейшей активности островов Уруп и Чирпой по итогам экспедиции «Восточный бастион - Курильская гряда 2021»

Сенциов А.А., Агибалов А.О

Роли пиар специалистов в научных организациях на примере ИФЗ РАН

Старикова А.Ю.

Активная тектоника и палеосейсмичность вдоль Краевого и Адырных разломов северной части Иссык-Кульской котловины (Кыргызстан, Тянь-шань) 
Стрельников А.А., Абдиева С.В., Старикова А.Ю., Корженков А.М.

Новейшая геодинамика Большого Кавказа

Фадеева К.В.....

Построение главных осей сжатия и растяжения по светодальномерным данным на Камчатском геодинамическом полигоне методом тензометрического анализа

Фаттахов E.A.. .65

Позднепалеозойский этап формирования северного сегмента Центрально-Азиатского складчатого пояса: палеомагнитные ограничения

Федюкин И.В..... .66

Исследование магнитной текстуры с целью определения направления течения магмы на примере разновозрастных даек Мурманского кратона (Кольский полуостров)

Фурсова С.А., Веселовский Р.В 67

Подготовка оперативных гелиогеофизических данных для Центра космической погоды в интересах безопасности авиаперелётов

Холодков К.И., Алёшин И.М., Аракелов А.С., Буров В.А., Васильев А.Е., Иванов С.Д..68

Оценка активности естественной трещиноватости на основе построения ЗД геомеханической модели нефтяного месторождения

Хуснутдинов Ф.Ф., Нугманов И.И.

Применение Рамановской спектроскопии для локализации источников сноса обломочного циркона

Чистякова А.В., Веселовский Р.В., Семёнова Д.В

Определение толщины земной коры по состоянию равновесия Эйри (на примере Восточного Узбекистана)

Шукуров 3.Ф 


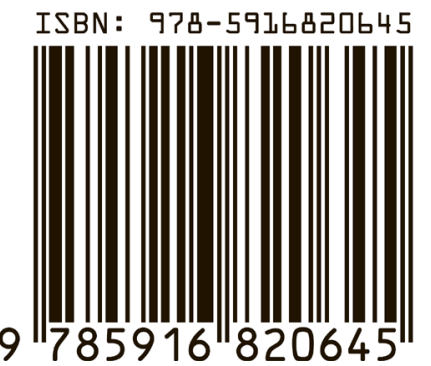

Научное издание

Научная конференция молодых ученых и аспирантов ИФЗ РАН, 27-29 октября 2021 г.

Тезисы докладов и программа Конференции

Ответственный редактор:

д.г.-М.н. Р.В. Веселовский

Редактор: к.г.-м.н. А.М. Фетисова

Оригинал-макет подготовлен в ИФЗ РАН

123242 Москва, ул. Б. Грузинская, д. 10 стр.1

Москва, 2021 